九州大学学術情報リポジトリ

Kyushu University Institutional Repository

\title{
Lower Cretaceous Marine Pelecypods of Japan Part III
}

Hayami, Itaru

Faculty of Science, Kyushu University

https://doi.org/10.5109/1543643

出版情報：九州大學理學部紀要：Series D, Geology. 17 (3)，pp.151-249，1966-09-15. Faculty of Science, Kyushu University バージョン：

権利関係 : 
Mem. Fac. Sci., Kyushu Univ., Ser. D, Geology, Vol. XVII, No. 3, pp. 151-249, 11 text-figs., 2 tables, pls. 22-26, September 15, 1966

\title{
Lower Cretaceous Marine Pelecypods of Japan \\ Part III
}

\author{
By \\ Itaru HAYAMI
}

\begin{abstract}
This is a serial comprehensive study on the Lower Cretaceous pelecypods of Japan, except for the trigoniids, the pachyodonts and the brackish- and fresh-water species. In the present part 19 species belonging to the Asthenodontida and the Eudesmodontida are described systematically on the basis of many specimens which were collected from various sedimentary areas by stratigraphers and palaeontologists including myself. 4 new species are proposed.

As the result of this study it is recognized that the Aritan ( $\doteqdot$ upper Neocomian) and the Miyakoan (except for the uppermost part) $(\div$ AptianAlbian) pelecypods are represented by about 50 and about 130 species respectively. Their stratigraphic occurrence are noted, and their faunal significance is discussed in some detail. The pelecypods of the two epochs are more or less clearly distinguishable from the Berriasian and earlier ones represented in Japan by the "Torinosu-type" fauna and also from the post-Albian ones which are well known in the uppermost Miyakoan and Gyliakian of Hokkaido and Kyushu. The faunal resemblance between the Japanese Aptian and the Lower Greensand of England is especially worthy of note.
\end{abstract}

\section{Contents}

4. Systematic descriptions (continued from Part II) $\ldots \ldots \ldots \ldots \ldots 2$

Order Asthenodontida ............................ 152

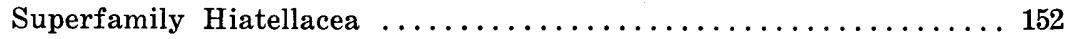

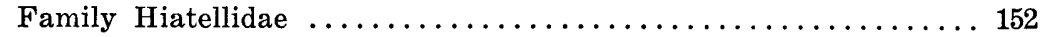

Genus Panopea MÉnard la Groye, $1807 \ldots \ldots \ldots \ldots \ldots \ldots \ldots$

Subgenus Myopsis Agassiz, $1840 \ldots \ldots \ldots \ldots \ldots \ldots \ldots \ldots$

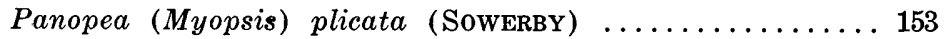

Panopea (Myopsis) nagaoi sp. nov. .............. 155

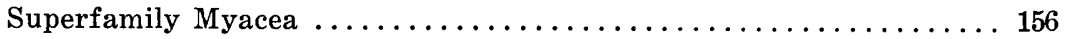

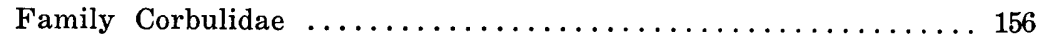

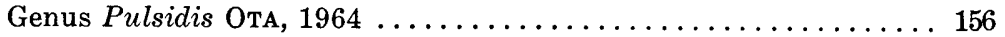

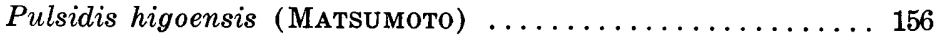

Order Eudesmodontida .......................... 157

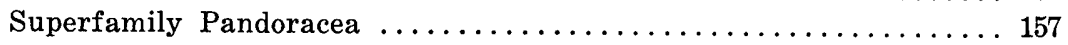

Family Pholadomyidae .......................... 157

Genus Pholadomya Sowerby, $1823 \ldots \ldots \ldots \ldots \ldots \ldots \ldots$

Pholadomya miyamotoi NAGAo ............... 157

Manuscript received May 25, 1966

Continued from Part I [Mem. Fac. Sci., Kyushu Univ., Ser. D, Vol. XV, No. 2, pp. 221349, text-figs. 1-4, pls. 27-52, March 1, 1965] and Part II [Ibid., Ser. D, Vol. XVII, No. 2, pp. 73-150, pls. 7-21, December 20, 1965] 
Pholadomya brevitesta NAGAO ............... 158

Pholadomya subpedelnalis NAGAo .............. 160

Pholadomya tuberculata sp. nov. .............. 160

Pholadomya sp. aff. $P$. cornueliana (D'ORBIGNy) ....... 162

Pholadomya sp. A indet. ................ 162

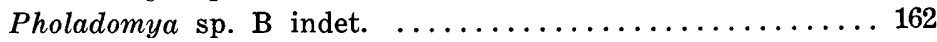

Genus Goniomya Agassiz, $1838 \ldots \ldots \ldots \ldots \ldots \ldots \ldots \ldots \ldots \ldots \ldots$

Goniomya subarchiaci NAGAo ............... 163

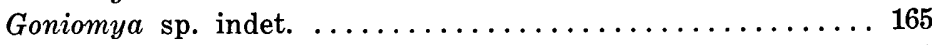

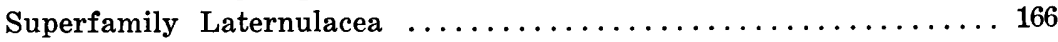

Family Laternulidae $\ldots \ldots \ldots \ldots \ldots \ldots \ldots \ldots \ldots \ldots \ldots \ldots$

Genus Cercomya Agassiz, $1842 \ldots \ldots \ldots \ldots \ldots \ldots \ldots \ldots \ldots \ldots$

Cercomya gurgitis (PICTET and CAMPICHe) ......... 166

Genus Plectomya DE LoRIoL, $1868 \ldots \ldots \ldots \ldots \ldots \ldots \ldots \ldots$

Plectomya aritagawana sp. nov. .............. 168

Plectomya sp. aff. P. anglica Woons ............. 169

Family Periplomatidae ....................... 169

Genus Offadesma IREdALE, $1930 \ldots \ldots \ldots \ldots \ldots \ldots \ldots \ldots$

Offadesma altissimum sp. nov. ................ 169

Family Thraciidae ........................ 170

Genus Thracia Blainville, $1824 \ldots \ldots \ldots \ldots \ldots \ldots \ldots \ldots$

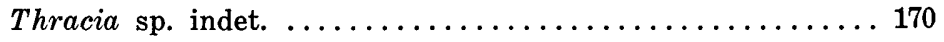

Genus Corimya Agassiz, $1842 \ldots \ldots \ldots \ldots \ldots \ldots \ldots \ldots \ldots \ldots \ldots$

Corimya (?) tanohatensis sp. nov. ............. 171

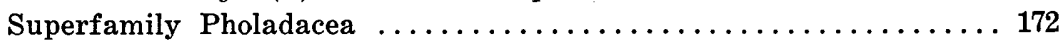

Family Teredinidae ....................... 172

Genus Teredo LinnaEus, $1758 \ldots \ldots \ldots \ldots \ldots \ldots \ldots \ldots \ldots \ldots$

"Teredo" matsushimaensis HATAI .............. 172

5. Stratigraphic occurrences of Lower Cretaceous marine pelecypods in

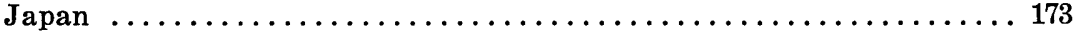

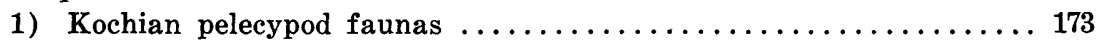

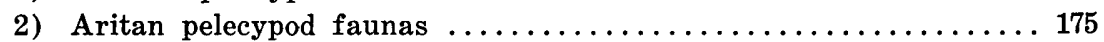

3) Miyakoan pelecypod faunas $\ldots \ldots \ldots \ldots \ldots \ldots \ldots \ldots \ldots \ldots \ldots$

6. Some remarks on the faunal characters $\ldots \ldots \ldots \ldots \ldots \ldots \ldots \ldots \ldots$

1) Faunal changes in the Lower Cretaceous of Japan . . . . . . . . 191

2) Foreign elements in the Lower Cretaceous Pelecypods of Japan . . . 192

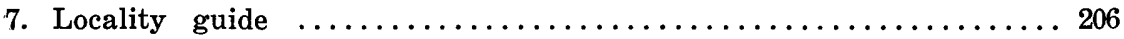

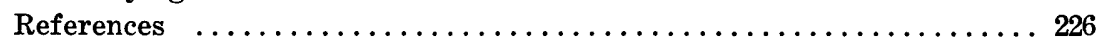

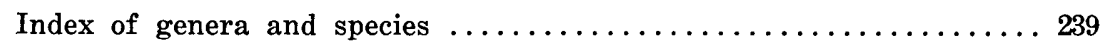

\section{Systematic Descriptions [continued from Part II]}

Order Asthenodontida

Superfamily Hiatellacea

Family Hiatellidae

Genus Panopea MÉnARd DE LA GroYe, 1807

(= Glycymeris LAMARCK, 1799, non DA CosTA, 1778;

Panope auct.; Panopaea auct.)

Type-species.-Panopea aldrovandi MÉNARD DE LA GROYE, 1807, Recent, Mediterranean Sea (monotypy). 
Subgenus Myopsis AGassiz, 1840

Type-species.-Mya mandibula SowERBY, 1813, Crctaceous, England (designated by Cox, 1964).

Remarks.-Myopsis AgAssiz, 1840, the type-species of which was recently designated by Cox (1964), is applicable for a number of Cretaceous species of Panopea. Myopsis appears to be distinguishable from Panopea (s. s.) by the narrower, more prominent and more anteriorly placed umbo.

\section{Panopea (Myopsis) plicata (SowerBY) \\ Plate 22, Figures 1-7}

1823. Mya plicata Sowerby, Min. Conch. Great Britain, Vol.5, p. 20, pl.419, fig. 3.

1835. Panopaea plicata, Sowerby, Ibid., Vol. 6, index, p. 241.

1852. Panopaea plicat́a, Pictet and Roux, Moll. fossil. verts de Genève, p. 399, pl. 28, fig. 2.

1852. Panopaea rhodani PicteT and Roux, Ibid., p. 400, pl. 28, fig. 3.

1858. Panopaea plicata, Pictet and Renevier, Fossil. du terrain aptien, pp. 56, 175, pl. 6, figs. $1,2$.

1909. Panopea gurgitis, Woons, Monogr. Cret. Lamell. England, Vol. 2, p. 222, pl. 35, figs. 9-14, pl. 36, figs. 1-8 (non Brongniart, 1822).

1926. Panopea sp. aff. gurgites (BRONGNIART), YABE, NAGAO and SHIMIZU, Sci. Rep. Tohoku Imp. Univ., Ser. 2, Vol. 9, Pt. 3, p. 55, pl. 12, figs. 10, 15, 19, 20. (sic)

1934. Panope sp. aff. gurgitis (Brongniart), NAGAO, Jour. Fac. Sci., Hokkaido Imp. Univ., Ser. 4, Vol. 2, No. 3, p. 231, pl. 31, figs. 10, 14.

1940. Panope cf. gurgitis (BRongniart), ImLAy, Bull. Geol. Soc. America, Vol. 51, p. 154, pl. 6, figs. 7, 8.

1954. Panopea gurgitis, Cox, Jour. Paleont., Vol. 28, No. 5, p. 634, pl. 67, fig. 9 (non BrongNiart, 1822).

1957. Panopea (?) sp., Amano, Kumamoto Jour. Sci., Ser. B, Sec.1, Vol.2, No. 2, p. 106, pl. 2, fig. 12.

Material.-Ten specimens (GK. H6535-GK. H6540, GK. H6711-GK. H6714) from the Miyako area (HANAI and HAYAMI coll.) are concerned with the description below.

Description.-Shell small- or medium-sized for the genus, equivalve, very inequilateral, transversely elongated, oblong, strongly inflated; length slightly smaller than twice the height; test very thin; antero-dorsal margin short, faintly concave in front of the umbo, passing gradually into the anterior margin; postero-dorsal margin long, nearly straight, forming an obtuse angle at the junction with the siphonal margin; siphonal margin rounded, widely gaping; umbo comparatively narrow, incurved, rising a little above the dorsal margin, orthogyrous, placed at about one-third of shell-length from the anterior extremity; a blunt carina extending from the umbo to the antero-ventral margin, defining a steep anterior slope which is usually a little concave; postero-dorsal area somewhat flattened but not clearly delimited; surface marked with irregularly spaced concentric plications on the middle and posterior areas; numerous radial threads composed of serial microscopic granules, covering the whole surface, 
although they are seen only in well preserved specimens; pallial sinus broadly rounded, fairly profound; adductor impressions obscure.

Measurements in $\mathrm{mm}$.

Specimen
Left valve (GK. H6535)
Left valve (GK. H6536)
Right valve (GK. H6537)
Left valve (GK. H6538)
Left valve (GK. H6539)
Left valve (GK. H6540)
Right valve (GK. H6711)
Right valve (GK. H6712)
Right valve (GK. H6713)
Left valve (GK. H6714)

$\begin{array}{cccl}\text { Length } & \text { Height } & \text { Thickness } & \text { L/H } \\ 49.5+ & 41.0 & 12.0 & 1.21+ \\ 55.5 & 33.0 & 9.5 & 1.68 \\ 53.0 & 29.5 & 9.0 & 1.79 \\ 42.0 & 23.5 & 6.5 & 1.79 \\ 37.0 & 20.0 & 6.0 & 1.85 \\ 87.5 & 49.0 & 15.5 & 1.79 \\ 47.5+ & 31.0 & 9.0 & 1.53+ \\ 23.0 & 12.0 & 3.5 & 1.92 \\ 37.5 & 22.0 & 6.0 & 1.70 \\ 30.5+ & 21.0 & 5.5 & 1.40+\end{array}$

Observations and comparisons.-The outline and the position of umbo are rather constant, although the prominence of the anterior carina is somewhat variable. In some specimens the antero-dorsal area seems slightly concave, but it is nearly flat in others. The characteristic radial ornament is clearly observed in a broken left valve (GK. H6535) and some other specimens. In a left valve, the test of which is almost exfoliated, a deeply sinuated pallial line is traceable. The hinge structure is not observable in the present material. However, a small prosocline conical umbonal tooth at the bottom of a triangular depression and a well defined post-umbonal plate for the adherence of ligament are clearly seen in one of NAGAO's specimens (1934, pl. 31, fig. 10, GH. reg. no. 6810), which was described as Panope aff. gurgitis and evidently conspecific with the present specimens.

The present specimens are specifically indistinguishable from the Lower Greensand ones described by Woons (1909) as Panopea gurgitis (BRoNGNIART). The radial threads bearing numerous microscopic granules may or may not be preserved in the British and Japanese specimens, but are very similar between them. Although the outline may recall that of Pleuromya AGAssiz, 1842, the hinge structure is of Panopea-type as was ascertained by Woods and NAGAO.

Mya plicata SowerBY, 1823, and Pholadomya neocomiensis LEYMERIE were synonymized with Panopea gurgitis by Woods (1909) as a result of his comprehensive study of this group. However, BRoNGNIART's holotype of Lutraria guargitis was refigured by CossmanN (1911), and its outline is quite different from Woods' specimens of $P$. gurgitis in the much shorter antero-dorsal margin and smaller ratio of length/height. They appear to be at least specifically different. CossmanN (1911) is probably right in stating that Woods' lumping of $M$. plicata, L. gurgitis and $P$. neocomiensis in a single species is erroneous. In fact, LEYMERIE's original figure of Pholadomya neocomiensis, though its photographic illustration is not available at present, shows more remarkably tapering posterior area and almost closed siphonal margin. WooDS (1909) described some specimens under the name of Panopea gurgitis var. neocomiensis, 
but they are probably different from LEYMERIE's original specimens and may be conspecific with Woons' specimens of "P. gurgitis". Some Argentine specimens of Panopea neocomiensis (WEAVER, 1931) show similar radial threads, but the outline is slightly narrower than the present specimens. Cox (1954) supported Woops' treatment of this group, referring a species from the Lower Cretaceous of Trinidad to $P$. gurgitis. That species appears to be conspecific with the present specimens.

Although the synonymies among various related species of Panopea (Myopsis) from the Lower Cretaceous should be further studied on the basis of their type specimens, the present specimens are provisionally referred to $P$. plicata owing to the close resemblance to the Lower Greensand specimens. The average size of the Japanese specimens appear slightly smaller than that of Woods', and the concentric undulations appear to be less persistent on the postero-dorsal area. But the difference may not require a subspecific distinction. Panopea (?) sp. of AMANo (1957) is, if not conspecific with, closely related to the present species, because the external features are quite similar to the present specimens.

Occurrence.-Aritan to upper Miyakoan (upper Neocomian to Albian). Calcareous sandstone of the Hiraiga formation at loc. Hn. 0017, 0018, southern coast of Hiraiga, and at loc. Hn. 0155 , northern coast of Hiraiga, Tanohata village, Shimohei County, Iwate Prefecture. Grey sandy shale of the "Orbitolina sandstone" of the Miyako group at loc. Hn. 6203, northeast of Raga, the same village. Similar specimens from the Ishido formation at loc. Hy. 4002, Ichinosebashi, south of Kagahara, Nakazato village, Tano County, Gumma Prefecture (ICHIKAWA and HAYAm coll.), and also from the Hagino formation at Hagino, Mirafu village, Kami County, Kochi Prefecture.

\section{Panopea (Myopsis) nagaoi sp. nov.}

\section{Plate 22, Figure 8}

1954. Pleuromya nagaoi MATSumoto, Cretaceous System, Japan. Islands, p. 115, nom. nud.

Material.-The holotype is a bivalved internal mould (GK. H6545) collected from the Yatsushiro formation at loc. Km. 3096, southwest of Kohara, Toyo village, Yatsushiro County, Kumamoto Prefecture (Kanmera coll.). Paratypes (GK. H6544, GK. H6546) from the type locality (KANMERA and HAYAMI coll.) and another paratype (GK. H6715) from the Yuasa area (MATsumoto coll.).

Description.-Shell small for the genus, highly inequilateral, Pleuromya-like in outline, much longer than high, strongly inflated; antero-dorsal margin obliquely sloping down into the rounded anterior margin; postero-dorsal margin much longer, nearly horizontal or slightly concave, forming a rounded obtuse angle with the obliquely truncated posterior margin; anterior area more or less flattened and probably gaping at the extremity; umbo placed anteriorly, orthogyrous, rising a little above the dorsal margin; surface marked with irregularly spaced strong concentric folds which diminish away from the postero-dorsal area; post-umbonal plate of Panopea-type well developed; musculature unknown. 
Measurements in $\mathrm{mm}$.

Specimen

Holotype (GK. H6545) right in. mould

Paratype (GK. H6544) both in. mould

Paratype (GK. H6546) left in. mould

$\begin{array}{cccl}\text { Length } & \text { Height } & \text { Thickness } & \text { L/H } \\ 37.0 & 20.5 & 8.0 & 1.80 \\ 31.5+ & 22.0 & 18.0 & 1.43+ \\ 22.5 & 11.5 & 5.0 & 1.96\end{array}$

Observations and comparisons.-The present specimens are rather poorly preserved and their tests are completely eroded away. Although the shellconvexity appear unusually strong, the material may be suffered from considerable secondary deformation. The concentric folds are irregular but very strong, and the umbonal plate, the trace of which is seen in the paratype (GK. H6544), suggests Panopea instead of Pleuromya. Moreover, the anteriorly placed umbo indicates that the present species belongs to the subgenus Myopsis.

The present species is distinguishable from Panopea (Myopsis) plicata (SowERBY, 1823) from the Aptian-Albian of England, Japan and many other areas of the world by the more prominent concentric folds, slightly more anteriorly placed umbo, stronger convexity and smaller size. Radial threads are not observable in the present material, probably because of the unfavourable preservation.

Occurrence.-Aritan and upper Miyakoan (upper Neocomian to Albian). Fine grey sandstone and sandy shale of the Yatsushiro formation at loc. $\mathrm{Km}$. 3097, southwest of Kohara, Toyo village, Yatsuhiro County, Kumamoto Prefecture. Fine sandstone of the same formation at loc. Km. 1843, north of Shimofukami, Sakamoto town, the same county. Fine grey sandstone of the Arita formation at loc. Ys. 103, west of Kumai, Yuasa town, Arita County, Wakayama Prefecture.

Superfamily Myacea

Family Corbulidae

Genus Pulsidis OTA, 1964

Type-species.-Pulsidis nagatoensis OTA, 1964, Lower Neocomian, west Japan (original designation).

\section{Pulsidis higoensis (MATSUMOTO)}

1938. Aloidis (Caryocorbula) higoensis Matsumoto, Jour. Geol. Soc, Japan, Vol. 45, No. 532, p. 19, pl. 2, fig. 8, text-fig. 9.

1964. Pulsidis higoensis, OtA, Mem. Fac. Sci., Kyushu Univ., Ser. D, Vol.15, No. 1, p. 153, pl. 21, figs. 13-17, text-fig. 3.

The present species is not represented in the present collection.

Occurrence.-Black fine sandstone and shale of the Yatsushiro formation (mainly Albian) at a locality $2 \mathrm{~km}$ south of Miyaji, Yatsushiro City, Kumamoto Prefecture. The present species was originally reported by MATSUмото (1938) from the medium to rather coarse-grained sandstone of the member of the Gosyonoura group (Albian-Turonian) at Gosyonoura island, Kumamoto Prefecture. 
Order Eudesmodontida

Superfamily Pandoracea

Family Pholadomyidae

Genus Pholadomya SowerBY, 1823

(=Procardia MEEK, 1871; Flabellomya ROLLIER, 1913)

Type-species.-Pholadomya candida Sowerby, 1823, Recent, West Indies (monotypy).

\section{Pholadomya miyamotoi NAGAo}

Plate 22, Figures 9-14; Plate 23, Figures 3-5

1943. Pholadomya (?) miyamotoi NAGA0, Jour. Geol. Soc. Japan, Vol. 50, p. 158, pl. 12, figs. 8,9 .

Material.-NAGAO (1943) established the present species on the basis of two specimens from the Hiraiga formation at Hiraiga, Tanohata village, Shimohei County, Iwate Prefecture. The figure numbers of his plate were in part erroneously given. The figures $8 \mathrm{a}, 9$ and $9 \mathrm{~b}$ represent a left valve, which is designated here as the lectotype. The specimen in figs. 8, $9 \mathrm{a}$ is another example of this species. Six specimens (GK. H6547-GK. H6552) from the type area are also concerned with the description below (HANaI and HaYami coll.).

Description.-Shell small-sized for the genus, scarcely exceeding $30 \mathrm{~mm}$. in length, equivalve, inequilateral, transversely ovate, not much elongated, about 1.2 times longer than high, strongly inflated; test very thin; antero-dorsal margin sloping down into the rounded anterior margin, while postero-dorsal margin is much longer and broadly concave; ventral margin broadly arcuate, not clearly delimited from the posterior margin; posterior area flattened, weakly auriculate; umbo orthogyrous, highly prominent, incurved, placed at about two-fifths of length from the anterior extremity; surface covered with radial and concentric plications which are strongly impressed on the internal surface; radials 18-24 in number, narrow but very sharp, roof-shaped, crowded on the antero-median area but becoming gradually more sparse and stronger towards the posterior, not distributed on the flattened posterior area and anterior peripheral area; sometimes weak radial ribs of secondary order inserted; concentric ribs confined to the antero-median area, somewhat sinuous, composed of numerous fine granulations at the intersections with the radial plications; growth-lines comparatively weak; hinge and musculature not observable.

Measurements in $\mathrm{mm}$.

Specimen

Right valve (GK. H6547)

Right valve (GK. H6548)

Right valve (GK. H6549)

Left valve (GK. H6550)

Right valve (GK. H6551)

Right valve (GK. H6552)

$\begin{array}{cccc}\text { Length } & \text { Height } & \text { Thickness } & \mathrm{L} / \mathrm{H} \\ 16.5 & 13.0 & 4.0 & 1.27 \\ 21.0 & 18.0 & 6.0 & 1.18 \\ 16.5 & 13.5 & 4.5 & 1.22 \\ 15.0 & 12.0 & 4.0 & 1.25 \\ 22.5 & 16.5+ & 7.5 & 1.36- \\ 22.0 & 18.0 & 6.5 & 1.22\end{array}$


Observations and comparisons.-The present material is generally well preserved, although the test is fragile and mostly exfoliated. NAGAo's type specimens are slightly larger than the present ones, but the outline and the characteristic ornamentation are quite identical. The number of radial plications varies to a great extent among individuals, ranging from 17 to 25 .

Pholadomya cornueliana (D'ORBIGNY, 1844) from the Aptian of France and the Lower Greensand of England (Woons, 1909) must be a closely allied species to the present one, and the latter might be actually a geographical subspecies of the former. Surface granulations are not clearly drawn in the figures of $P$. cornueliana in D'ORBIGNY's and MoEsCH's monographs, but they are clearly shown in Woops' (1909) description and illustration. Pholadomya subdinnensis (D'ORBIGNY, 1846), which was regarded by MoESCH as a synonym of $P$. cornueli$a n a$, is also very similar to the present species in the outline and ornamentation. However, the concentric ribs of typical European specimens of $P$. cornueliana are not sinuous and more persistent than in $P$. miyamotoi, and accordingly the ornamentation appears more regularly cancellate on the antero-median surface of $P$. cornueliana. The posterior flattened area is wider, and the distributed area of granulations is probably narrower than in that species.

Pholadomya shattucki Böse, 1910 (=Pholadomya roemeri SHATTUCK, 1902, non Whitfield, 1885) from the Cenomanian of Mexico and Texas (PERKins, 1960) differs from the present species in the more equidistantly spaced radial plications and in the much larger size.

Pholadomya aff. cornueliana recorded by Amano (1957) from the Hagino formation of Shikoku is probably related to the present species, but its posterior area is less pronouncedly auriculate and the surface seems to be covered with non-sinuous concentric plications than in the present specimens. $P$. miyamotoi is clearly distinguishable from Pholadomya subpedelnalis NAGA0, 1934, from the Miyako group, by the more numerous radial plications, although they are somewhat similar in the outline and dimensions.

Occurrence.-Lower Miyakoan (Aptian). Calcareous sandstone of the Hiraiga formation at loc. Hn. 0017, 0018, southern coast of Hiraiga, Tanohata village, Shimohei County, Iwate Prefecture.

\section{Pholadomya brevitesta NAGAO \\ Plate 23, Figure 2}

1943. Pholadomya brevitesta NAGA0, Jour. Geol. Soc. Japan, Vol.50, No. 596, p. 157, pl. 13, fig. 3 .

Material.-The holotype by monotypy is a bivalved specimen illustrated by NAGAO (1943, pl. 13, fig. 3, 3a, 3b). It was collected from the Tanohata formation at Koikorobe, Tanohata village, Shimohei County, Iwate Prefecture. A specimen (GK. H6554) from the type area (HANAI coll.) is also concerned with the description below.

Description.-Shell of medium size, equivalve, inequilateral, gibbose in outline, longer than high, moderately inflated; test thin; antero-dorsal margin 
very short; postero-dorsal margin long, nearly straight, passing gradually into the rounded siphonal margin; ventral margin broadly arcuate; maximum convexity lying anteriorly from the center; umbo placed very anteriorly, incurved, slightly prosogyrous, rising a little above the dorsal margin; anterior peripheral area obscurely delimited from the remainder by a shallow sulcus which extends from the umbo to the antero-ventral area; posterior area slightly flattened, gaping at the extremity; surface ornamented with radial and concentric plications; radials about 17 in number, irregularly spaced, much narrower than their interspaces, confined to the antero-median surface; no radial rib on the anterior and posterior areas; concentric plications covering the whole surface, about 35 in number, rather regularly spaced, round-topped, much broader than their interspaces, forming a network with the radials; granules weakly developed at the intersections; musculature and hinge structure unknown. Specimen (GK. H6554) both valves, $55.0 \mathrm{~mm}$. long, $47.0 \mathrm{~mm}$. high, $32.0 \mathrm{~mm}$. thick.

Observations and comparisons.-A well preserved bivalved specimen at hand is probably conspecific with the holotype of Pholadomya brevitesta NAGAo, 1943, because the ornamentation and the mode of anterior sulcus are quite similar. The holotype is apparently shorter than the present one and nearly as high as long. The umbo seems to be more prominent in the holotype than in the present specimen. It is, however, possible that the differences are partly due to the secondary deformation of the holotype. At the localities of NAGA0's and the present specimens closed pelecypod shells are apt to be deformed owing to the soft matrices. Supposing the original outline is better preserved in the present specimen, the present species is not much apart from Pholadomya collombi COQUAND, 1866, from the Aptian-Cenomanian strata of western Europe (MOESCH, 1875), but the radial ornament is more crowded and more irregularly spaced than in that species. Pholadomya esmarki (NILsson, 1827) (GoldFuss, 1836; MOESCH, 1875) from the upper Lower and Upper Cretaceous of Europe may be also allied to the present species in some respects, but the concentric ribs seem to be more prominent in $P$. brevitesta. Pholadomya martini ForBes, 1845, from the Lower Greensand of England and the Neocomian of Germany (WollemanN, 1900; Woods, 1909) resembles the present species in the outline, but the posterior unornamented area is narrower in the former than in the latter.

Pholadomya japonica AMANo, 1956, from the Gyliakian Miyanohara sandstone of southern Shikoku may be related to the present species, but the posterior flattened area is distinctly narrower than in the latter.

Occurrence.-Lower Miyakoan (Aptian). Black sandy shale of the Tanohata formation at loc. Hn. 0006, southern coast of Hiraiga, Tanohata village, Shimohei County, Iwate Prefecture. NAGAO's holotype came from the same formation at Koikorobe in the same village. A similar specimen was obtained from the Ishido formation at loc. Hy. 4001, Ichinose-bashi, south of Kagahara, Nakazato village, Tano County, Gumma Prefecture (HAYAmi coll.). 


\section{Pholadomya subpedelnalis NAGAo}

Plate 23, Figure 1

1934. Pholadomya subpedelnalis NAGAo, Jour. Fac. Sci., Hokkaido Imp. Univ., Ser. 4, Vol. 2, No. 3, p. 214, pl. 26, fig. 8 .

Material.-The holotype by monotypy is a bivalved specimen (GH. reg. no. 6796) illustrated by NAGAo (1934, pl. 26, fig. 8). It was collected from the "Hiraiga sandstone" of Hideshima, Miyako City, Iwate Prefecture. A specimen (GK. H6558) newly collected from the type area is also concerned with the description below.

Description.-Shell very small, equivalve, very inequilateral, trigonally ovate, rostrated posteriorly, much longer than high, moderately inflated; antero-dorsal margin weakly concave, passing gradually into the anterior margin; anterior margin subvertical, slightly gaping; postero-dorsal margin broadly concave; siphonal margin well delimited but short; umbo placed slightly anteriorly from the mid-point of length; a sharp carina extending from the umbo to the posterodorsal extremity, defining a deeply concave area corresponding to the escutcheon; surface ornamented with 10 , widely spaced and subequidistant radial ribs and irregularly folded concentric ribs; small tubercles produced at their intersections; concentric ribs much weakened and radial ribs absent on the antero-dorsal and postero-dorsal areas; hinge structure and musculature unknown. Specimen, GK. H6558, closed internal mould, $17.5 \mathrm{~mm}$. long, $14.0 \mathrm{~mm}$. high, $8.5 \mathrm{~mm}$ thick.

Observations and comparisons.-The present specimen is a bivalved internal mould, the test of which is completely eroded away. The ornamentation is, however, well recognized on the internal surface. The present specimen is certainly conspecific with Pholadomya subpedelnalis NAGA0, 1934, from the Miyako group in view of the similar mode of surface ornamentation. The ratio of length/height of the present specimen is slightly larger than in NAGAO's holotype, but the difference may be attributed to the strong deformation of the latter specimen, because fossils are generally more or less strongly deformed at the type locality. Pholadomya miyamotoi NAGAO, 1943, resembles the present species in the posteriorly rostrate outline, but the radial ribs of $P$. subpedelnalis are distinctly fewer and more equidistantly spaced, the concentric ribs being more prominent and more widely spaced than in the present species.

Occurrence.-Lower and upper Miyakoan (Aptian to Albian). Grey sandy shale of the upper part of the "Orbitolina sandstone" of the Miyako group at loc. Hn. 6203, northeast of Raga, Tanohata village, Shimohei County, Iwate Prefecture. NAGAo's holotype came from the "Hiraiga sandstone" (probably the 2nd cycle sediments of the Miyako group) at Hideshima of Sakiyama, Miyako City, the same prefecture.

Pholadomya tuberculata sp. nov.

Plate 24, Figures 1-3

Material.-The holotype is a left valve (GK. H6555) collected from the 
Hiraiga formation at loc. Hn. 0018, southern coast of Hiraiga, Tanohata village, Shimohei County, Iwate Prefecture (HAYAmi coll.). Paratypes (GK. H6556, GK. H6557) from the type locality (HAYAMI coll.).

Description.-Shell comparatively small-sized, scarcely $30 \mathrm{~mm}$. in length, very inequilateral, transversely elongated, oblong, not rostrated, moderately inflated; test rather thick for the genus; antero-dorsal margin obliquely truncated, short; postero-dorsal margin nearly straight, very long; anterior and posterior margins smoothly rounded, probably gaping to a certain extent; ventral margin broadly arcuate; anterior sulcus absent; umbo rather improminent, broad, slightly prosogyrous, placed at about one-fourth of shell-length from the anterior extremity; a conspicuous ridge extending subhorizontally along the postero-dorsal margin, delimiting clearly a narrow area corresponding to escutcheon; surface ornamented with weak radial and concentric ribs; radial ribs about 8 in number, much narrower than their interspaces, distributed on the umbonal and median surface, becoming much weaker and soon disappeared towards anterior, posterior and ventral areas; concentric lamellae broad, fairly irregular in density and prominence, forming conspicuous tubercles at the intersections with the radial ribs; growth-lines comparatively weak; hinge and musculature unknown.

\section{Measurements in $\mathrm{mm}$.}

\section{Specimen}

Holotype (GK. H6555) left valve

Paratype (GK. H6556) left valve

Paratype (GK. H6557) left valve

$\begin{array}{cccl}\text { Length } & \text { Height } & \text { Thickness } & \text { L/H } \\ 25.0 & 15.0 & 4.5 & 1.67 \\ 18.0+ & 14.5 & 5.0 & 1.24+ \\ 20.5+ & 15.5 & 5.0 & 1.32+\end{array}$

Observations and comparisons.-The present species is now represented only by three left valves. The holotype reveals a complete outline. The test is almost exfoliated in the holotype but well preserved in one of the paratypes (GK. H6556), the posterior part of which is broken off.

The present species is readily distinguishable from Pholadomya miyamotoi NAGAO, 1943, Pholadomya brevitesta NAGA0, 1943, and Pholadomya subpedelnalis NAGA0, 1934, from the same sedimentary area by the smaller number of radial ribs, less prominent umbo, more transversely elongated and oblong outline and more persistent concentric lamellae. Pholadomya ovula AGASSIZ, 1842 (MORRIS and LYCETT, 1853; MOESCH, 1875) from the Great Oolite of England resembles the present species in some respects, but differs from it in the less concave postero-dorsal margin and the less tuberculate surface. Pholadomya pedelnalis ROEMER, 1852 (MOESCH, 1875), from the Aptian of western Europe and Texas, and Pholadomya trigeriana CotTreau, 1855 (MoEsch, 1875), from the Neocomian of Swiss and France, show much larger dimensions and more prominent umbones, although the surface ornamentation and some other characters are similar. Pholadomya rogeri FreneIx, 1958, from the Senonian of New Caledonia has more densely spaced radial ribs and much larger dimensions. Pholadomya connectans ForBEs, 1840 from the Valudayur group of southern India (STOLICZKA, 1871) resembles the present species in the outline and ornamentation, but a 
conspicuous groove extends subvertically from the umbo to the ventral margin in that species.

Occurrence.-Lower Miyakoan (Aptian). Calcareous sandstone of the Hiraiga formation at loc. Hn. 0017, 0018, southern coast of Hiraiga, Tanohata village, Shimohei County, Iwate Prefecture.

\section{Pholadomya sp. aff. P. cornueliana (D'ORBIGNY)}

1957. Pholadomya aff. cornueliana (D'ORBIGNy), AmANo, Kumamoto Jour. Sci., Ser. B, Sec.1, Vol. 2, No. 2, p.92, pl. 2, fig. 9.

Remarks.-The present species is not represented in this collection. As compared by AmANo, it seems to be close to Pholadomya cornueliana (D'ORBIGNY, 1844) from the Aptian of France and the Lower Greensand of England (Woods, 1909) in view of the outline and ornamentation. It is likewise similar to Pholadomya miyamotoi NAGA0, 1943, from the Miyako group, but distinguishable from that species by the more persistent and non-sinuous concentric ribs.

Occurrence.-Lower Miyakoan (Aptian). Weathered sandstone of the Hagino formation at Hagino, Mirafu village, Kami County, Kochi Prefecture (according to AMANO, 1957a).

\section{Pholadomya sp. A indet.}

Plate 24, Figure 4

This species is represented at present by an internal mould of left valve (GK. H6781, 43.0 + mm. long, $40.0 \mathrm{~mm}$. high, $16.5 \mathrm{~mm}$. thick). The test is completely eroded away and the posterior part is broken. In the shell-size it is comparable with Pholadomya brevitesta NAGA0, 1943, from the Miyako group, but the radial ribs are subequidistantly spaced and the concentric ribs are, if present, very weak in the present species. It resembles more closely Pholadomya speetonensis WooDs, 1909, from the Speeton Clay of England, in the general outline and surface sculpture, but the shell is more obliquely elongated in the present species.

Occurrence.-Lower Miyakoan (Aptian). Weathered sandstone of the Hagino formation at loc. Hy. 6011, Hagino, Mirafu village, Kami County, Kochi Prefecture (OGAWA coll.).

\section{Pholadomya sp. B indet.}

Plate 24, Figures 5-6

This species is represented by two specimens: one is a closed internal mould and the other is a left internal mould (GK. H6791, $37.5 \mathrm{~mm}$. long, $22.5 \mathrm{~mm}$. high, $16.0 \mathrm{~mm}$. thick; GK. H6792, $24.5 \mathrm{~mm}$. long, $16.0 \mathrm{~mm}$. thick, $5.5 \mathrm{~mm}$ thick). It has similar concentric ribs to Pholadomya brevitesta NAGA0, 1943, from the Miyako group, but are distinguishable from that species by the more transversely elongated outline and weaker radial riblets. In the outline the present species is somewhat similar to Pholadomya martini Forbes, 1845, from the Lower 
Greensand of England (WooDs, 1909), but the radial ornament may be much weaker in the former than in the latter.

Occurrence.-Aritan to upper Miyakoan (upper Neocomian to Albian). Dark grey sandy shale of the Hanoura formation at loc. Hy. 5002 (boulder), Hiroyasu, Katsuura town, Katsuura County, Tokushima Prefecture (HAYAmI coll.), and fine grey sandstone of the Yatsushiro formation at loc. $\mathrm{Km}$. 1843, north of Shimofukami, Sakamoto town, Yatsushiro County, Kumamoto Prefecture (KANMERA coll.).

Genus Goniomya Agassiz, 1838

(=Lysianassa MÜNSTER in GoLdFuss, 1836, non

MILNE-EDWARD, 1830)

Type-species.-Mya angulifera SowERBY, 1819, Middle Jurassic, western Europe (designated by HERRMANNSEN, 1846).

Remarks.-Goniomya is a well characterized Mesozoic pelecypod genus having particular V- or U-shaped ornaments. Certain species of the Grammysiidae from the Carboniferous and Permian of U.S.S.R. have Goniomya-like V-shaped sculpture and have been grouped as Pentagrammysia Tschernyshew, 1950 (type-species: $P$. altaica Tschernyshew). However, it is open to question whether the resemblance of sculpture is only due to a homoeomorphism or actually indicates phylogenetical relationship. It is also noticeable that the ornamentation of Undulomya Fletcher, 1946 (type-species: U. pleiopleura Fletcher, 1946) resembles that of some species of Goniomya. The type-species is known from the Permian of Australia, and Dickins (1956) transferred the genus from the Pholadomyidae to Arcomyidae on the basis of the presence of radiating rows of minute granules. Radially arranged punctations exist also in many species of Goniomya, and I maintain that Goniomya is phylogenetically intimate to Undulomya.

The classification of Goniomya, although it may be somewhat artificial, can be to a certain extent based on the development of the horizontal ribs of median set. In many species of Goniomya, median ribs are confined to the umbonal area, and the anterior and posterior ribs scribe Vs in the ventral area. But in some species from the Jurassic and Cretaceous, horizontal ribs are persistent throughout the growth. If the latter group was actually originated from the former, as presumed from the stratigraphic occurrence, the evolution may constitute a case of "neoteny".

\section{Goniomya subarchiaci NAGAO}

Plate 25, Figures 1-13

1934. Goniomya subarchiaci NAGAo, Jour. Fac. Sci., Hokkaido Imp. Univ., Ser. 4, Vol. 2, No. 3, p. 215, pl. 29, figs. 2, 3.

Material.-The holotype is a bivalved specimen (GH. reg. no. 6786) illustrated by NAGAO (1934, pl. 29, fig. 3). It was collected from the Aketo formation at the northeast of Raga, Tanohata village, Shimohei County, Iwate Prefecture. 
Another specimen of NAGAO (1934, pl. 29, fig. 2) is also an example of this species. 16 more specimens (GK. H6559-GK. H6566, GK. H6716-GK. H6723) from the type area (HANAI and HAYAMI coll.) are concerned with the description below.

Description.-Shell small- or medium-sized for the genus, equivalve, fairly inequilateral, elongate-elliptical, transversely elongated, moderately inflated; length smaller than twice the height; test very thin, translucent; antero-dorsal margin obliquely truncated; postero-dorsal margin slightly concave behind the umbo, much longer than the antero-dorsal; siphonal margin well delimited, forming an obtuse angle with the postero-dorsal margin; ventral margin broadly arcuate; umbo fairly prominent, orthogyrous, incurved, a little rising above the dorsal margin, placed at about one-third of shell-length from the anterior end; a weak carina extending from the umbo to the postero-ventral corner, defining obscurely a slightly concave and somewhat flattened postero-dorsal area; a pair of prominent ridges run subparallel to the antero- and postero-dorsal margins, delimiting narrow crescentic areas corresponding to the lunule and escutcheon; surface ornamented with characteristic U-shaped ribs of Goniomya-type, which are distributed on a triangular area covering the umbonal and central surface; umbonal angle of the triangle about 100 degrees, divided into three parts of about 40, 25 and 35 degrees from the anterior side; ribs of the anterior part about 14-16 in number, prosocline, prominent; ribs of the median part similar in number but more or less weakened towards the venter, nearly horizontal, forming an obtuse angle of about 140 degrees with the anterior set just below the umbo; ribs of the posterior part broad, smaller in number, opisthocline, meeting median horizontal ribs with obtuse angles of about 115 degrees; three sets of ribs generally continuous but sometimes median set truncated by posterior set; ribs never scribe Vs even in the adult stage; anterior, posterior and ventral areas of the shell nearly smooth except for faint growth-lines and many fine radial threads composed of numerous microscopic serial punctures; hinge and musculature unknown.

Measurements in $\mathrm{mm}$.

Specimen
Left valve (GK. H6559)
Left valve (GK. H6560)
Left valve (GK. H6561)
Right valve (GK. H6562)
Left valve (GK. H6563)
Right valve (GK. H6564)
Left valve (GK. H6565)
Left valve (GK. H6566)
Left valve (GK. H6716)
Left valve (GK. H6717)
Right valve (GK. H6718)
Left valve (GK. H6719)
Left valve (GK. H6720)
Left valve (GK. H6721)
both valves (GK. H6722)
Right valve (GK. H6723)

$\begin{array}{cccl}\text { Length } & \text { Height } & \text { Thickness } & \text { L/H } \\ 32.0 & 17.5 & 5.5 & 1.83 \\ 35.0 & 18.5 & 6.0 & 1.89 \\ 31.0 & 16.5 & 5.0 & 1.88 \\ 38.5 & 22.0 & 7.0 & 1.75 \\ 16.0 & 10.5 & 3.0 & 1.52 \\ 29.0+ & 17.0 & 5.5 & 1.71+ \\ 29.0 & 17.0 & 5.5 & 1.71 \\ 26.5 & 15.5 & 4.5 & 1.64 \\ 33.0 & 18.5 & 6.0 & 1.78 \\ 22.0 & 13.0 & 4.0 & 1.69 \\ 34.5 & 19.0 & 6.5 & 1.82 \\ 26.0+ & 17.0 & 5.5 & 1.53+ \\ 29.0 & 18.0 & 5.5 & 1.61 \\ 25.5 & 15.0 & 5.0 & 1.70 \\ 38.5 & 19.0 & 11.5 & 2.03 \\ 36.5 & 22.5 & 7.0 & 1.62\end{array}$


Observations and comparisons.-This species is represented in the present collection by a large number of well preserved specimens. Closed valves are not rare at some localities but usually ill-preserved and suffered from secondary deformation. The fragile test is mostly exfoliated or eroded away in many specimens, but completely preserved in a left valve (GK. H6716), which shows numerous rows of microscopic puctations (Pl. 25, Figure 2b). The ornamented area in these specimens except for immature ones is comparatively narrow, and the ribs of the median set (horizontal ribs) are moderately long throughout the growth. Although the ratio of length/height is fairly variable and ranges from 1.60 to 1.90 , all the specimens including NaGA0's type specimens show invariably $\mathrm{U}$-shaped ornamentation.

Goniomya nonvscripta TAMURA, 1959, from the Upper Jurassic Soma group of Northeast Japan, has also well developed and persistent median horizontal ribs. The ornamented area is, however, distinctly narrower in the present species than in G. nonvscripta and also than in many other Jurassic species.

As noted by NAGAO (1934), the present species may be closely related to Goniomya archiaci (PICTET and RENEVIER, 1858), from the Aptian of France and the Lower Greensand of England (Woods, 1909), but the former is distinguishable from the latter by the more anteriorly placed umbo, more rounded posterior margin and better differentiated ribs into three sets. The present species is somewhat similar to Goniomya caudata AGASSIZ, 1842 (=Pholadomya agassizii D'ORBIGNY, 1846), from the Neocomian of France, in the oblong outline, but the ornamented area is probably much narrower than in the European species, unless the illustrated specimens of G. caudata in AGASSIZ (1842) and D'ORBIGNY (1846) are immature. Moreover, the ribs of three sets are more sharply geniculated at the junctions in the present species.

Occurrence.-Lower and upper Miyakoan (Aptian to Albian). Calcareous sandstone of the Hiraiga formation at loc. Hn. 0016, 0017, 0018, southern coast of Hiraiga, grey sandy shale of the Tanohata formation at loc. Hn. 0220, northern coast of Hiraiga, grey sandy shale of the upper part of the "Orbitolina sandstone" at loc. Hn. 6202 and Hn. 6203, northeast of Raga, and grey sandy shale of the Aketo formation at loc. Hn. 6201, northeast of Raga, all in Tanohata village, Shimohei County, Iwate Prefecture. NAGAo (1934) noted that a similar specimen had occurred from the "Kawarazawa formation" of the Sanchu area.

Goniomya sp. indet.

Plate 24, Figure 7

This species is represented by two poorly preserved specimens: one is a left internal mould (GK. H6573, $15.5 \mathrm{~mm}$. long, $9.0 \mathrm{~mm}$. high, $3.5 \mathrm{~mm}$. thick) and the other is a right internal mould (GK. H6572, 21.0 $\mathrm{mm}$. long, $18.5 \mathrm{~mm}$. high, $5.5 \mathrm{~mm}$. thick).

Shell inequilateral, comparatively short, subtrigonal with nearly straight antero-dorsal and postero-dorsal margins; siphonal margin clearly demarcated; umbo narrow, pointed, orthogyrous, placed slightly anteriorly from the mid-point 
of length; ornamentation composed of three sets of ribs on the umbonal area, although the middle set (horizontal ribs) is soon shortened and disappeared on the middle surface to form V-shaped sculpture in the adult stage; hinge and musculature unknown.

The present species is clearly distinguishable from Goniomya subarchiaci NAGA0, 1934, from the Miyako group by the shorter shell and less persistent horizontal ribs of the median set and more sharply pointed umbo.

Occurrence.-Aritan and upper Miyakoan (upper Neocomian to Albian). Dark grey sandy shale of the Ishido formation at loc. Hy. 4001, Ichinose-bashi, south of Kagahara, Tano County, Gumma Prefecture (ICHIKaWA and Hayami coll.), and dark grey sandy shale of the Yatsushiro formation at loc. Km. 3096, southwest of Kohara, Toyo village, Yatsushiro County, Kumamoto Prefecture (KANMERA coll.).

\author{
Superfamily Laternulacea \\ Family Laternulidae \\ Genus Cercomya AgAssiz, 1842
}

Type-species.-Cercomya pinguis AGASsIZ, 1842, Lower Jurassic, western Europe.

\title{
Cercomya gurgitis (PICTET and CAMPICHe)
}

Plate 24, Figures 8-10

1858. Anatina robinaldina, Picter and Renevier, Matér. Pal. Suisse, sér.1, p. 63, pl. 7, fig. 1 (non $A$. robinaldina D'ORBIGNY, 1845)

1865. Anatina gurgitis PICTet and CAMPICHe, Ibid., Sér.4, p.105, pl.107, figs. 6-8.

1909. Anatina (Cercomya) gurgitis, Woons, Monogr. Cret. Lamell. England, Vol. 2, p. 238, pl. 39, figs. 2-4.

1934. Anatina (Cercomya) sp., NAGA0, Jour. Fac. Sci., Hokkaido Imp. Univ., Ser. 4, Vol. 2, No. 3, p. 216, pl. 32, fig. 2.

? 1957. Anatina (Cercomya?) sp., Amano, Kumamoto Jour. Sci., Ser. B, Sec. 1. Vol. 2, No. 2, p. 93, pl. 2, figs. 10, 11.

1961. Cercomya gurgitis, CASEY, Palaeontology, Vol. 3, Pt.4, p. 607, listed.

Material.-Three specimens (GK. H6574-GK. H6576) from the Miyako area (HANAI and HAYAMI coll.) are concerned with the description below.

Description.--Shell medium-sized, equivalve or subequivalve, very inequilateral, transversely elongated, remarkably rostrated and gradually tapering posteriorly, roundly truncated at the extremity, moderately inflated; test very thin; length attaining about three times the height; antero-dorsal margin nearly horizontal, gradually bending down to the rounded anterior margin; posterodorsal margin much longer than the antero-dorsal, broadly concave to the caudal end; umbo not prominent, broad, opisthogyrous, placed almost centrally or a little anteriorly from the mid-point of length; two rounded carinae running from the umbonal area to the posterior extremity, delimiting a shallow sulcus and a somewhat steep postero-dorsal slope; a very inconspicuous depression passes 
from the umbo obliquely forwards across the valve; anterior surface in front of the depression ornamented with irregularly spaced concentric ribs which are much narrower than their interspaces; concentrics much weakened on the posterior area; fine growth-lines covering the whole surface; antero-median surface provided with numerous faint radial rows which are composed of mciroscopic granules; valve margin apparently closed except for slightly gaped caudal end; hinge and musculature unknown.

Measurement in $\mathrm{mm}$.

$\quad$ Specimen
Both valves (GK. H6574)
Right in. mould (GK. H6575)
Left ex. mould (GK. H6576)

$\begin{array}{cccl}\text { Length } & \text { Height } & \text { Thickness } & \text { L/H } \\ 39.5 & 13.0 & 6.0 & 3.04 \\ 56.5 & 17.5 & 5.5 & 3.23 \\ 64.5+ & 23.5 & 7.5 & 2.74+\end{array}$

Observations and comparisons.-Three specimens in the present collection are specifically identical with the specimen from the same area, which was described by NAGAO (1934) as Anatina (Cercomya) sp. Although NAGAo's specimen is very incomplete, the outline and ornamentation of the anterior part are quite similar to those of the present specimens. The characteristic microscopic granules are clearly observable in one specimen (GK. H6574), but not seen in two other specimens owing to the unfavourable preservation.

In every essential character the present specimens agree well with Anatina (Cercomya) gurgitis PicteT and CAMPICHE, 1865, from the Aptian of France and the Lower Greensand of England (Woods, 1909). The posterior rostrum, ornamentation and weak oblique sulcus are especially similar to those of the Lower Greensand specimens. Anatina robinaldina (D'ORBIGNY, 1845) from the Hauterivian of France differs from the present species in the shorter outline and deeper oblique sulcus. The present specimens are also similar in the outline to Cercomya spatulata AGAssiz, 1842, from the "Portlandian" of France, but the concentric lamellae are more persistent on the posterior surface in the latter than in the former. Anatina (Cercomya?) sp. described by Amano (1957) from the Hagino formation of southern Shikoku is probably conspecific with C. gurgitis, but its specific identity cannot be decided at present, because the posterior rostrum is lacked in that specimen.

Many authors have considered Cercomya to be a subgenus of Anatina (=Laternula), but, as suggested by CASEY (1961), it should be separated generically from Laternula by the rostrated posterior area.

Occurrence.-Lower and upper Miyakoan (Aptian and Albian). Calcareous sandstone of the Hiraiga formation at loc. Hn. 0018, southern coast of Hiraiga, and grey sandy shale of the "Orbitolina sandstone" at loc. Hn. 6202, northeast of Raga, Tanohata village, Shimohei County, Iwate Prefecture. NAGAo (1934) reported the present species also from the Hiraiga formation at Haipe and from the Aketo formation at Aketo in the same village. A similar specimen from the weathered sandstone of the Hagino formation at Hagino, Mirafu village, Kami County, Kochi Prefecture (according to Amano, 1957). 
Genus Plectomya DE LORIOL, 1868

Type-species.-Tellina rugosa RöMER, Jurassic, western Europe (monotypy).

Plectomya aritagawana sp. nov.

Plate 25, Figures 14-15; Plate 26, Figure 2

1954. Laternula aritagawana Matsumoto, Cretaceous System, Japan. Islands, pp. 76, 113, listed (nom. nud.).

? 1957. Laternula sp., Amano, Kumamoto Jour. Sci., Ser. B, Sec. 1, Vol. 2, No. 2, p. 105, pl. 1, fig. 19 .

Material.-The holotype is a bivalved specimen (GK. H6577) which is composed of internal and external moulds. It was collected from the Arita formation at loc. Ys. 53, north of the pass between Yuasa and Yoshikawa, Yuasa town, Arita County, Wakayama Prefecture (Matsumoto coll.). A paratype (GK. H6578) from the type locality, and two other paratypes (GK. H6579, GK. Hob50) from the Yatsushiro area (KANMERA coll.).

Description.-Shell small- or medium-sized, apparently equivalve, transversely oblong, about twice as long as high, moderately inflated; test thin; antero-dorsal margin slightly convex, passing gradually into the anterior margin; posterodorsal margin broadly concave; siphonal margin obliquely truncated, widely gaping; umbo a little opisthogyrous, placed subcentrally; a fairly sharp carina extending from the umbo to the postero-ventral area, delimiting a wide posterior area; central part of the flank weakly constricted; flank ornamented with widely spaced concentric plications in the anterior part, while it is entirely smooth except for growth-lines in the posterior part; posterior area behind the carina smooth; umbonal fissure not observed; hinge unknown but probably edentulous; musculature unknown.

Measurements in $\mathrm{mm}$.

\begin{tabular}{|c|c|c|c|}
\hline Specimen & Length & Height & Thickness \\
\hline Holotype (GK. H6577) both valves & 22.0 & 12.0 & 6.5 \\
\hline Paratype (GK. H6578) left in. mould & 33.5 & 17.0 & 5.0 \\
\hline Paratype (GK. H6579) right in. mould & 25.0 & 12.5 & 4.0 \\
\hline
\end{tabular}

Observations and comparisons.-Four specimens and several fragments are available for the present study. Each shows a weak subvertical construction in the central part and widely spaced concentric plications in front of the constriction. All the external characters are well exhibited in the holotype, although its posterior carina may be emphasized by certain secondary deformation.

The present species has been known to some stratigraphers as Laternula aritagawana MATSUMоTо (MS). The presence of a distinct central constriction and characteristic anterior plications suggest that it belongs to Plectomya, although the posterior carination is more conspicuous than in any known species of this genus.

The present species is somewhat similar to Anatina carteroni D'ORBIGNY, 1843, A. marullensis D'OrbignY, 1843 , and $A$. cornueliana D'OrBIGNY, 1843 , from 
the Lower Cretaceous of France, all of which are referable to Plectomya. The posterior carina is, however, almost absent or very weak in those European species.

Occurrence.-Aritan to upper Miyakoan (upper Neocomian to Albian). Dark grey sandy shale of the Arita formation at loc. Ys. 53, north of the pass between Yuasa and Yoshikawa, Yuasa town, Arita County, Wakayama Prefecture. Grey fine sandstone of the same formation at loc. Ys. 103, a rail-road cutting, west of Kumai, the same town. Grey sandstone of the Yatsushiro formation at loc. $\mathrm{Km} .3113(\div \mathrm{Km} .3096)$, southwest of Kohara, Toyo village, Yatsushiro County, Kumamoto Prefecture. In addition, a few fragmentary specimens, which may be conspecific with the present species, were collected from the black shale of the Hanoura formation at loc. Hy. 5003, Hiroyasu, Katsuura town, Katsuura County, Tokushima Prefecture (Hayami coll.).

Plectomya sp. aff. $P$. anglica WooDs

Compare.-

Plate 25, Figure 16

1909. Plectomya anglica Woods, Monogr. Cret. Lamell. England, Vol. 2, p. 238, pl. 39, fig. 1.

A specimen composed of internal and external moulds of closed valves resembles the preceding species Plectomya aritagawana sp. nov., but differs from this species in the weaker construction, weaker posterior carina, narrower and less clearly delimited posterior area and the reappearance of concentric folds on the posterior part of the flank.

The last mentioned character is very similar to that of Plectomya anglica Woods, 1909, from the Lower Greensand of England. The specific identification is, however, impossible at present, because the material is secondarily compressed. Specimen, internal mould of closed valves (GK. H6600), $31.0 \mathrm{~mm}$. long, $19.0 \mathrm{~mm}$. high, $6.0+$ mm. thick.

Occurrence.-Upper Miyakoan (Albian). Grey fine sandstone of the Yatsushiro formation at loc. Hy. 1016, west of Mt. Jôgûsan, Miyaji, Yatsushiro City, Kumamoto Prefecture (HAYAMI coll.).

Family Periplomatidae

Genus Offadesma IREDALE, 1930

Type-species.-Periploma angasi CROSSE and FISCHER, 1864 (original designation).

Offadesma altissimum sp. nov.

Plate 26, Figure 1

Material.-The holotype is a bivalved internal mould (GK. H6581) collected from the upper part of the "Orbitolina sandstone" of the Miyako group at loc. Hn. 6203, northeast of Raga, Tanohata village, Shimohei County, Iwate Prefecture. 
Description.-Shell medium-sized for the genus, inequivalve, inequilateral, roundly rhomboidal in outline, tapering posteriorly, rostrated, subvertically truncated at the posterior extremity; test thin (holotype, GK. H6581, closed internal mould, $45.5 \mathrm{~mm}$. long, $30.5 \mathrm{~mm}$. high, $12.5 \mathrm{~mm}$. thick) ; left valve weakly convex, while right valve is fairly strongly inflated; antero-dorsal margin nearly straight; postero-dorsal margin as long as the antero-dorsal, somewhat angularly concave behind the umbo; ventral margin forms an obtuse chevron, its curvature being strong in the middle part; posterior part of the ventral margin nearly straight or a little concave; siphonal margin well delimited, more or less gaping, forming obtuse angles with the postero-dorsal and postero-ventral margins; umbo slightly opisthogyrous, pointed, rising a little above the dorsal margin, placed near the mid-point of length; posterior rostrated part remarkably flattened; surface apparently smooth except for growth-lines; umbonal area of right valve provided with a trace of short subvertical fissure; musculature and other internal structures unknown.

Observations and comparisons.-The present species is represented at present by a well preserved specimen. It resembles closely some living species of Off $a$ desma in the inequivalveness, outline and presence of an umbonal fissure, although the internal characters and surface granulations are not observable owing to the inadequate preservation. Several species from the Cretaceous have been referred to Periploma and other genera of the Periplomatidae, but their posterior rostrum is generally not so well developed as in the present species.

Some genera of the Thraciidae such as Cyathodonta Conrad, 1849, show similarly inequivalve and rostrated shell, but the presence of an umbonal fissure prevents me from referring it to that family. So far as I am aware, there is no comparable species of the Periplomatidae in the Cretaceous, and the present species may be the earliest representative of Offadesma.

Occurrence.-Upper Miyakoan (Albian). Grey sandy shale of the upper part of the "Orbitolina sandstone" of the Miyako group at loc. Hn. 6203, northeast of Raga, Tanohata village, Shimohei County, Iwate Prefecture (HAYAMI coll.).

\section{Family Thraciidae}

Genus Thracia Blainville, 1824

Type-species.-Thracia corbuloidea BlAINviLle, 1824, Recent (designated by GrAY, 1847).

Thracia sp. indet.

Plate 26, Figure 3

This species is represented by a left valve. Shell small, inequilateral, subelliptical, not much elongated, weakly inflated (GK. H6583, $24.5 \mathrm{~mm}$. long, $\mathbf{1 7 . 5} \mathrm{mm}$. high, $3.5 \mathrm{~mm}$. thick) ; test very thin; anterior margin smoothly arcuate without any angulation; postero-dorsal margin slightly concave behind the umbo, slightly shorter than the antero-dorsal; posterior margin subvertically truncated, forming an obtuse angle with the postero-dorsal margin; posterior area not 
rostrated but remarkably flattened; umbo comparatively narrow, slightly opisthogyrous, rising a little above the dorsal margin; surface smooth except for weak growth-lines; internal characters unknown.

The test of the present specimen is almost entirely exfoliated, but partly preserved on the postero-dorsal area. In the outline the present species resembles some species of Periploma Schmacher, 1817, and Periplomya Conrad, 1870. It differs, however, from the former in the absence of umbonal fissure and chondrophore and from the latter in the absence of internal ridge. It is probably a member of Thracia. In many external characters the present specimen is similar to Thracia sp. of WooDs (1909, p. 243, pl. 40, figs. 7-9) from the Gault and Upper Greensand of England, although the dimensions of the present specimen are much smaller. Thracia robinaldina (D'ORBIGNY, 1845), from the Lower Greensand of England (WooDs, 1909), is also similar to the present species but shows more transversely elongated outline. CASEY (1961) referred the former species to Periplomya, but the latter, as noted above, is not a member of that genus.

Occurrence.-Lower Miyakoan (Aptian). Calcareous sandstone of the Hiraiga formation at loc. Hn. 0017, southern coast of Hiraiga, Tanohata village. Shimohei County, Iwate Prefecture (HAYAmi coll.).

Genus Corimya AGASsIz, 1842

Type-species.-Corimya pinguis AGASsiz, 1842, Jurassic, Western Europe (designated by SToLICZKA, 1871).

Corimya (?) tanohatensis sp. nov.

Plate 26, Figures 4, 5

Material.-The holotype is a bivalved internal mould (GK. H6724) from the Tanohata formation at the southern coast of Hiraiga, Tanohata village, Shimohei County, Iwate Prefecture (Hanai and Hayami coll.). Paratype (GK. H6725) from the type locality (HANAI and HAYAMI coll.).

Description.-Shell small, inequilateral, subequivalve, rounded in front and subquadrate backwards, moderately inflated; test thin; antero-dorsal margin rounded, passing gradually into the anterior; postero-dorsal margin longer than the antero-dorsal, nearly straight, obliquely truncated by the well delimited siphonal margin; a very sharp carina extending from the umbo to the posteroventral angle, delimiting clearly a posterior area, which is obtuse-triangular and remarkably flattened or even slightly concave; umbo rather broad, placed near the mid-point of length; surface of the main part ornamented with broadly plicated concentric ribs, which are weakened towards the anterior periphery and posterior carina; posterior area wholly marked with regular oblique riblets parallel to the posterior siphonal margin; internal characters unknown.

Measurements in $\mathrm{mm}$.

Specimen

Holotype (GK. H6724) both valves

Paratype (GK. H6725) both valves

$\begin{array}{cccc}\text { Length } & \text { Height } & \text { Thickness } & \text { L/H } \\ 21.5 & 16.0 & 5.0 & 1.34 \\ 20.0 & 13.5 & 8.0 & 1.47\end{array}$


Observations and comparisons.-The holotype is nearly complete but secondarily compressed. The paratype is incomplete but the original shell-convexity is better preserved. The test of the two specimens was replaced by carbonaceous substance, but the surface sculpture is well preserved. The posterior carina is similarly strong in the two valves of both specimens.

Posteriorly carinated species of the Thraciidae from the Jurassic and Cretaceous are generally referable to Corimya AGASSIz, 1842, but the present species possesses a still sharper posterior carina than any species of typical Corimya. It seems to be congeneric with Lutraria? carinifera SowERBY, 1826, from the Cenomanian-Turonian of England and France, in view of the similar sharp carina and surface sculpture. AGAssiz (1842) included that species in Corimya, although D'ORBIGNY (1845) and some others referred it to Lyonsia and Woops (1909) to Thracia. It is highly probable that $L$ ? carinifera and the present species belong to a certain unnamed genus of Eudesmodontida. But the systematic position of the two species cannot be decided at present, because their internal characters have not been clarified.

It is noteworthy that the present species is somewhat similar to the species of "Cuspidaria" from the Upper Triassic and Jurassic. As pointed out by Cox (1960, p. 73), those species may not be early representatives of typical Cuspidaria. They show Cuspidaria-like rostrated outline, but a more or less sharp posterior carina, which is absent in Recent species of the Cuspidariidae, is well developed and defines sharply a flattened posterior area. It is possible that those species of "Cuspidaria" were rather ancestral to these Cretaceous species in question.

Specifically, the present species is distinguishable from $L$ ? carinifera by the more conspicuous concentric ornamentation on the flank and the narrower posterior area. It is also similar to Lyonsia elegans D'OrBIGNY, 1845, from the Cenomanian of France but differs from that species in the less elongated outline and stronger concentric ribs. It may be also congeneric with Panopea rotundata SowERBY, 1836, from the Lower Greensand of England, which was referred to Thracia by WooDs (1909) and CASEY (1961, p. 607), but the latter has more globose shell and weaker concentric sculpture than the present species.

Occurrence.-Lower Miyakoan (Aptian). The present specimens were collected from a boulder of grey sandy shale at the southern coast of Hiraiga, Tanohata village, Shimohei County, Iwate Prefecture. Judging from the lithology, the boulder was certainly derived from the Tanohata formation exposed there.

\section{Superfamily Pholadacea \\ Family Teredinidae}

Genus Teredo LinnaEus, 1758

Type-species.-Teredo navalis LINNAEUs, 1758, Recent (by ICZN, Opinion 94).

"Teredo" matsushimaensis HATAI

Plate 26, Figures 6-9 
1951. Teredo matsushimaensis HataI, Inst. Geol. Palaeont. Sendai, Short Paper, No. 3, p. 30, pl. 5, figs. 1-5.

Remarks.-HATAI (1951) established Teredo matsushimaensis on the basis of several calcified tubes and five isolated valves from the "Hiraiga sandstone" of the Miyako group at Matsushima islet of the Moshi area*, Iwaizumi town, Iwate Prefecture. These specimens (IGPS reg. no. 73697) were collectively treated by him as "syntype". The illustrated bivalved specimen (HATAI, 1951, pl. 5, figs. 1, 3, 4), which was obtained from a certain tube in the petrified wood (pl. 5, fig. 5), is designated as the lectotype.

Numerous tubes were found in several pieces of drift wood at the type locality, and some of them are illustrated here. An ill preserved left valve (GK. H6777, 11.0+ mm. long, $12.0 \mathrm{~mm}$. high, $4.5 \mathrm{~mm}$. thick) was obtained from the termianl part of a tube. This specimen shows a similar median constriction and other essential characters to the lectotype. A narrow tube (GK. H6776) was collected from a shell bed of Hiraiga. It is probably of the same species.

The up-to-date classification of the Teredinidae should be based mainly on the morphology of pallets, which are formed at the posterior end of the tube. Because the character is not observable in the specimens from the Miyako group, the taxonomic position of this species is difficult to be determined at present.

Occurrence.-Lower Miyakoan (Aptian). Drift woods in the calcareous sandstone of the 2nd cycle sediments of the Miyako group at loc. Hn.4154, Matsushima, off the coast of Moshi, Iwaizumi town, Shimohei County, Iwate Prefecture (HANAI coll.). Calcareous sandstone of the Hiraiga formation at loc. Hn. 0017, southern coast of Hiraiga, Tanohata village, the same county (HAYAMI coll.).

\section{Stratigraphic occurrence of Lower Cretaceous marine pelecypods in Japan}

\section{1) Kochian pelecyod faunas}

The Kochian (approximately lower Neocomian) series of Japan is generally represented by widely distributed embayment, estuarine or deltaic sediments. It is probably due to an extensive emergence of this age, and the facies is in many respects comparable with that of the Wealden in Northwestern Europe. The series, however, forms commonly one sedimentary cycle in many areas of Southwest Japan. Pelecypods in this series are mostly brackish-water species. Bakevellia, Ostrea, Protocardia, Protocyprina, Eomiodon, Neomiodon, Isodomella and Tetoria are very common in the Kochian sediments, forming frequently striking cyrenoid banks. Some of these genera are found also in certain purely marine sediments of other series, but the absence of cephalopods, corals, echinoids,

* In the original description the locality was said to be "Matsushima, Taro-mura", but it is probably erroneous, because the Miyako group is distributed at Matsushima of Moshi and not at Matsushima of Taro. 
crinoids and any other marine organisms suggests that these pelecypod faunas prospered under some conditions of unstable salinity such as a profound embayment and an estuary. The palaeontological study on these brackish-water faunas has been undertaken by many authors (NAUMANN and NEUMAYR, 1890; YABE, NaGaO and Shimizu, 1926; Kobayashi and SuzUki, 1939; OTA, 1964; HaYAMi and NAKAI, 1965, etc.), and is still now in progress.

The Kawaguchi formation of the Kuma area, the Ryoseki formation of the Kochi, Monobegawa and Sakawa area, the Tatsukawa formation of the Katsuuragawa area, the Yuasa formation of the Yuasa-Aritagawa area, the Shiroi formation of the Sanchu area and the Yoshimo formation of the Shimonoseki area have been regarded as the member of the Kochian series in view of their stratigraphic position. Bakevellia shinanoensis, Ostrea ryosekiana, Protocyprina naumanni, Eomiodon sakawanus, Neomiodon otsukai, Isodomella shiroiensis and Tetoria (Paracorbicula) sanchuensis are widely distributed and predominant pelecypods in the cyrenoid beds of these formations. They have been collectively called "Ryoseki fauna", but similar specific assemblages are known also in Aritan and Miyakoan brackish-water faunas. Only Protocyprina naumanni (NEUMAYR) is apparently confined in occurrence to this series. In Northeast Japan, some of these species including $P$. naumanni are known to occur from the Ayukawa formation of the Ojika area and also (?) from the Omoto formation of the Miyako area. As described before (HAYAMI, 1960), the brackish-water fauna of the Jusanhama formation of the Hashiura area of South Kitakami mountains may be Lower Cretaceous in age, but lacks any element of the "Ryoseki fauna".

On the other hand, marine pelecypods are rather rare in the Lower Neocomian of Japan. Only small marine pelecypod faunas of a Berriasian age are known to occur in the Kesennuma area of the south Kitakami mountains and in the Soma area of the north Abukuma mountains. They are accompanied by Thurmanniceras, Berriasella, Spiticeras, "Olcostephanus", Kilianella and some other ammonites in the former area and by Thurmanniceras, Berriasella and Parakilianella in the latter area (SATo, 1958, 1961).

From the Isokusa formation at Isokusa and Nagasaki of the Kesennuma area the following pelecypods have been described (KoBAYASHI and TAMURA, 1955; HaYami, Sugita and Nagumo, 1960):

Parallelodon (Torinosucatella) kobayashii (TAMURA)

Grammatodon takiensis KIMURA

Grammatodon sp.

Variamussium sp. cf. V. habunokawense (KIMURA)

Limatula akiyamae HAYAMI

Myophorella (Promyophorella) obsoleta KoBAYASHI and TAMURA

Astarte (Astarte) sp. cf. A. (A.) spitiensis STOLICZKA

Astarte (Astarte) sp.

Pleuromya sp.

Some of these species are common with the fauna of the upper part of the Kogoshio formation, which bears Substeueroceras and a few other ammonites of an 
upper Tithonian age.

The Koyamada formation of the Soma area, which covers conformably the Tithonian strata of the main part of the Soma group, bears the following pelecypods (KoBayashi and TAMURA, 1955; TAMURA, 1959-1960):

Parallelodon sp. aff. $P$. inflatus TAMURA

Grammatodon takiensis KIMURA

Entolium kimurai TAMURA

Myophorella (Promyophorella) orientalis KoBAYASHI and TAMURA

Astarte kambarensis KimURA

Eriphyla (Miyakoella) subdepressa (BLAKE and HUdLESToN)

Protocardia tosensis KIMURA

Corbula (?) globosa TAMURA

All the species of the Koyamada formation are the elements of the Torinosu fauna, which are widely distributed in the Upper Jurassic of the Outer Zone of Southwest Japan and Northeast Japan.

A trigoniid faunule found in the Yamanokami sandstone of the Sakawa area of Shikoku has been considered to be Kochian by many geologists. At Yamanokami, i.e. the southern slope of Mt. Ohira of the Sakawa area, the sandstone apparently covers the Upper Jurassic Torinosu group, but their stratigraphic relationship cannot be determined owing to the poor exposure. The faunule is composed of Nipponitrigonia kikuchiana, N. naumanni, Rutitrigonia yeharai, Pterotrigonia pocilliformis "var. yamanokamiensis" and some other undescribed pelecypods (KoBAYASHI, 1957; KoBAYASHI and NAKano, 1958). The specific assemblage is similar to that of the Aritan fauna and not to the Upper Jurassic and Berriasian ones, and the age of this faunule is presumed to be Valanginian or later. Some marine pelecypod beds exist in the Ryoseki group of the Kaisekiyama belt of the Sakawa area (KoBAYAsHI, 1939). Although the fauna is not yet observed, the assemblage has been said to be similar to that of the Aritan fauna.

The Uminoura formation in the Kuma area of Kyushu, which passes gradually from the Aulacosphinctes- and Himalayaites-bearing Tithonian strata of the Sakamoto formation (TAmURA, 1961; TAKAI et al., 1963 ed.), bears some marine pelecypods. It may be a marine representative of the Kochian series, as TAMURA compared it with the Yamanokami sandstone of the Sakawa area. However, no determinable pelecypod has been described.

\section{2) Aritan pelecypod faunas}

The Aritan (approximately upper Neocomian) series constitutes as a whole the second sedimentary cycle of the Japanese Cretaceous. It is mainly composed of marine sediments, although some brackish-water shells are found in the lower part of the sequence in some areas. It is probably because of an extensive transgression and a continuing inundation of this age. Marine pelecypods are fairly common in various areas of Northeast Japan and the Outer Zone of Southwest Japan. 
Table 1. Stratigraphic position of Lower Cretaceous marine pelecypod-bearing formations in Japan (Hayami, 1966)

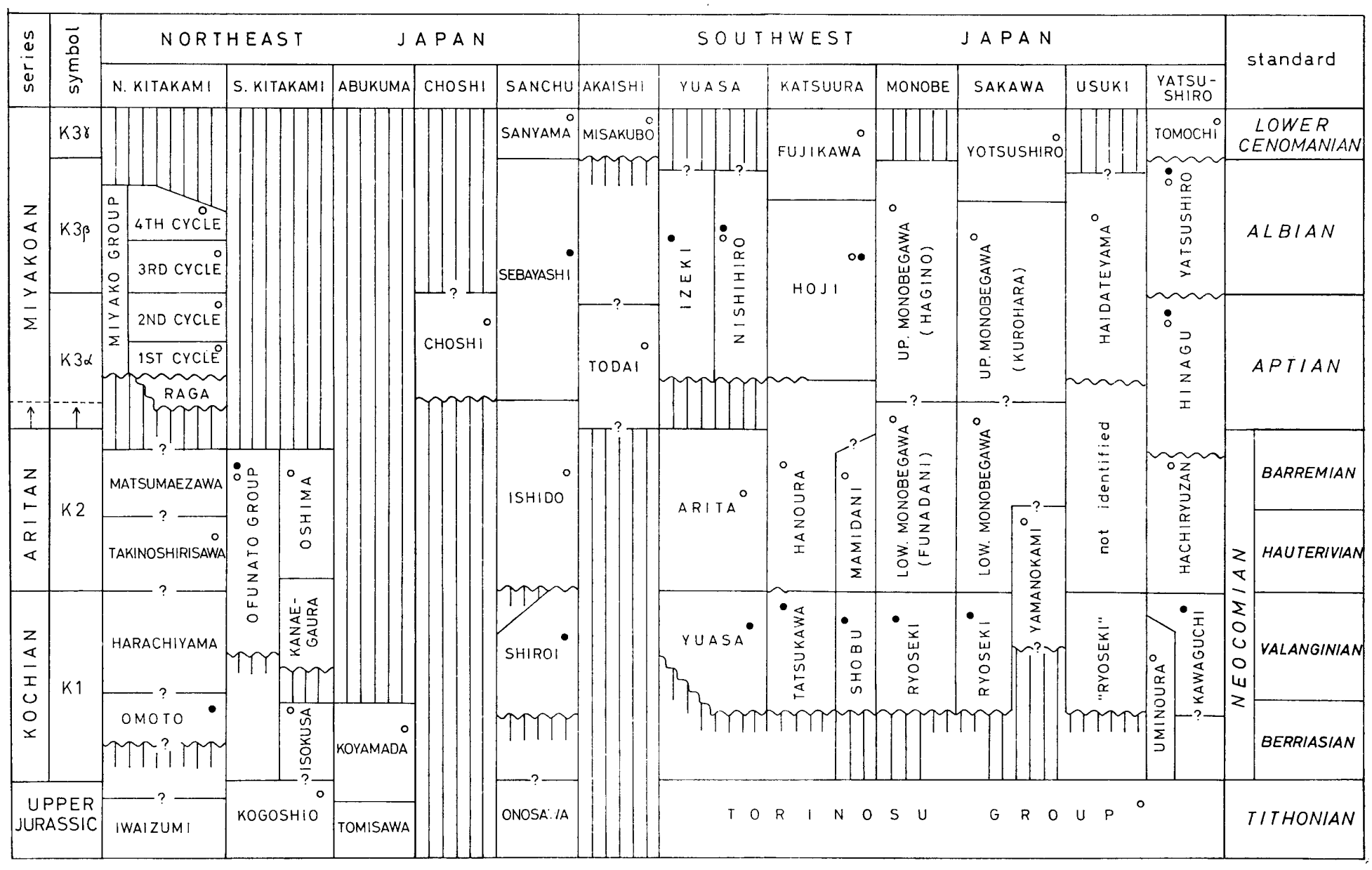

The correlation is tentative.

- marine pelecypod-bearing formation

- brackish-or fresh-water pelecypod-bearing formation 
Aritan pelecypods are well represented by the fauna of the Ishido formation of the Sanchu area in the frontier region of Nagano, Gumma and Saitama Prefectures. YokoYama (1890) and YABe, NAGAO and ShImizu (1926) described 16 pelecypods from this formation at Ishido, south of Kagahara and some other localities. Pulchellia ishidoensis, Leptoceras asiaticum, Crioceratites yagii and a few other ammonites occur at Ishido in the western part of this area (YABE, NAGAO and SHIMIZU, 1926), indicating an upper Neocomian age at least for a part of this formation. The Ishido formation is widely distributed also in the eastern part of the Sanchu area, and bears many marine pelecypods at the south of Kagahara, the southern slope of Mt. Kanozan and some other localities. As recently pointed out by TAKEI (1963), the fossil localities of the "Kawarazawa formation" in YABE, NAGAO and SHIMIZU's index map (1926) belong at least in part to the Ishido formation of the present usage. The following species have been already described from the Ishido formation or are distinguishable in the present collection (locality number in brackets) :

Nuculopsis (Palaeonucula) ishidoensis (YABE and NAGAO)*

Nuculana (s. l.) sanchuensis YABE and NAGAO [Hy. 4001, 4002]

Nanonavis (Nanonavis) yokoyamai (YABE and NAGAO) [Hy. 4001, 4002, 4003, 4011, 4013]

Trigonarca obsoleta YABE and NAGAO*

Amygdalum ishidoense (YABE and NAGAO) [Hy. 4011]

Gervillaria haradae (YoKoYAMA) [Hy. 4001, 4008, 4011]

Gervillia (Gervillia) forbesiana D'ORBIGNY [Hy. 4001, 4011]

Isognomon (Melina) ichikawai sp. nov. [Hy. 4011]

Pinna sp. cf. $P$. robinaldina D'ORBIGNY [Hy. 4011]

Neithea (Neithea) kanmerai sp. nov. [Hy. 4011]

Neithea (Neithea) sp.

Neithea (Neithella) sp. cf. N. (N.) atava (RöMER) [Hy. 4011]

Entolium sanchuense sp. nov. [Hy. 4001]

Limatula ishidoensis (YABE and NAGAO) [Hy. 4011]

Lopha (Arctostrea) carinata (LAMARCK) [Hy. 4001, 4011]

Nipponitrigonia plicata KOBAYASHI and NAKANO (?=Nipponitrigonia sanchuensis MAEDA) [Hy. 4011]

Nipponitrigonia kikuchiana (YoKоYAMA)*

Pterotrigonia yokoyamai (YEHARA) [Hy. 4011]

Pterotrigonia pocilliformis (YoKoYAMA) [Hy. 4001, 4002, 4003, 4008, 4011, 4013]

Rutitrigonia sanchuensis (NAKANO) [Hy. 4011]

Rutitrigonia yeharai KoBAYASH*

Astarte (Astarte) subsenecta YABE and NAGAO [Hy. 4001, 4002, 4003, 4008, 4011]

Astarte (Astarte) costata YABE and NAGAO [Hy. 4003]

Astarte (Yabea) shinanoensis YABE and NAGAO [Hy. 4003]

\footnotetext{
* Species not represented in the present collection.
} 
Eriphyla (Eriphyla) minima sp. nov. [Hy. 4003]

Pachythaerus kagaharensis (YoKoYAMA) [Hy. 4001]

Anthonya sp. aff. A. subcantiana NAGAo [Hy. 4001]

Laevicardium (?) ishidoense (YABE and NAGAO)*

Ptychomya densicostata NAGAo [Hy. 4001]

Panopea (Myopsis) plicata (SowERBY) [Hy. 4002]

Pholadomya brevitesta NAGAo [Hy. 4001]

Goniomya sp. [Hy. 4001]

The Arita formation in the Yuasa-Aritagawa area of Wakayama Prefecture contains also marine pelecypods and ammonites of an upper Neocomian age. Phyllopachyceras sp. cf. $P$. infundibulum, Australiceras asiaticum, Shasticrioceras nipponicum, Hamulina sp. cf. H. subcylindrica and a few other ammonites have been reported (MATsumoto, 1947). The following pelecypods are here identified:

Nuculopsis (Palaeonucula) ishidoensis (YABE and NAGA0) [Ys. 105]

Nuculana (s. l.) sanchuensis YABE and NAGAo [Ys. 3, 8]

Nanonavis (Nanonavis) yokoyamai (YABE and NAGA0) [Ys. 8, 53, 105]

Modiolus falcatus Amano [Ys. 103]

Modiolus sp. aff. M. subsimplex D'ORBIGNY [Ys. 103]

Pterinella shinoharai sp. nov. [Ys. 329a]

Gervillia (Gervillia) forbesiana D'ORBIGNY [Ys. 329a]

Neithea (Neithea) kanmerai sp. nov. [Ys. 103]

Variamussium kimurai sp. nov. [Ys. 8]

Plicatula kiiensis sp. nov. [Ys. 103]

Lopha (Arctostrea) carinata (LAMARCK)*

Nipponitrigonia kikuchiana (YoKoYAMA)*

Nipponitrigonia naumanni (YEHARA)*

Pterotrigonia pocilliformis (YoKоYамA) [Ys. 8, 103]

Astarte (Astarte) subsenecta YABE and NAGAo [Ys. 103]

Lucinoma (?) sp. [Ys. 8]

Ptychomya densicostata NAGA0 [Ys. 103]

Panopea (Myopsis) nagaoi sp. nov. [Ys. 103]

Plectomya aritagawana sp. nov. [Ys. 53, 103]

In the Katsuuragawa basin of Tokushima Prefecture, the Aritan series seems to be represented by the Hanoura formation, although its upper part may be referable to lower Aptian**. Phyllopachyceras infundibulum, Barremites pseudodifficilis, Silesites sp. cf. S. seranonis, Hamulina sp. cf. H. subcylindrica, Pseudothurmannia hanourensis and Pulchellia sp. cf. $P$. ishidoensis have been reported from this formation (YABE, 1927; YABE and SHIMIZU, 1931; etc.), although this fauna has not been fully described. The following pelecypods have been known or collected mainly from the middle and upper parts of this formation:

** The ammonites of the Hanoura formation need a further careful study, because their identifications will serve fundamentals for the international correlation of the Aritan series. The biostratigraphy of the Katsuuragawa basin is now studied by Mr. I. NAKaI. See also the postscript II of this paper. 
Nuculopsis (Palaeonucula) ishidoensis (YABE and NAGAO) [Hy. 5002, 5011]

Nuculana (s. l.) sanchuensis YABE and NAGAO [Hy. 5010]

Nanonavis (Nanonavis) yokoyamai (YABE and NAGAO) [Hy. 5002]

Pterinella shinoharai sp. nov. [Hy. 5002, 5004]

? Gervillia (Gervillia) forbesiana D’ORBIGNY [Hy. 5002]

Neithea (Neithea) kanmerai sp. nov. [Hy. 5004]

Neithea (Neithella) sp. cf. N. (N.) atava (RöMER) [Hy. 5002]

Lopha (Arctostrea) carinata (LAMARCK)*

Pterotrigonia pocilliformis (YoKOYAMA) [Hy. 5001]

Pterotrigonia sp. cf. P. yokoyamai (YEHARA) [Hy. 5002]

Astarte (Astarte) subsenecta YABE and NAGAO [Hy. 5004, 5012, 5015]

Scittila japonica sp. nov. [Hy. 5003]

Scittila sp. [Hy. 5001]

Astarte (Yabea) sp. aff. A. (Y.) shinanoensis YABE and NAGAo [Hy. 5002]

? Panopea (Myopsis) plicata (SoWERBY) [Hy. 5004]

Plectomya aritagawana sp. nov. [Hy. 5003]

Furthermore, Hirayama et al. (1956) listed Cucullaea aff. acuticarinata, Spondylus cf. decoratus, Gervillaria cf. haradae, Laevicardium (?) ishidoense and Ptychomya aff. densicostata from the Hanoura formation.

The Mamidani formation, which is distributed in a narrow area to the south of the Katsuuragawa basin, is probably also a representative of the Aritan series. Hirayama et al. (1956) listed "Propeamussium cowperi var. yubarensis", Limatula ishidoensis, Gervillia aff. forbesiana, Pterotrigonia pocilliformis, Astarte (Astarte) subsenecta, Anthonya sp. and some other marine pelecypods, although I have not as yet observed the fauna of this formation.

In the Monobegawa basin of Kochi Prefecture the Aritan series is represented by the Lower Monobegawa subgroup called Funadani or Yunoki formation, although the biostratigraphic data are still insufficient to yield definite evidence as to the chronology. Lopha (Arctostrea) carinata, Nipponitrigonia kikuchiana and Pterotrigonia pocilliformis have been reported to occur in this part (KATTO et al., 1961, etc.). In addition, the following species occur in this subgroup at the mouth of a valley, Okunominotani, northwest of this basin:

Barbatia sp. [Hy. 6002]

Chlamys shikokuensis AmaNo [Hy. 6002]

Variamussium kimurai sp. nov. [Hy. 6002]

Astarte (Astarte) sp. [Hy. 6002]

Pelecypods are also comparatively rare in the Lower Monobegawa subgroup of the Sakawa-Ochi area of Kochi Prefecture. Only Pterotrigonia pocilliformis and Astarte (Astarte) subsenecta have been reported from the environs of Ochi (HUKUTI, 1941).

The Hachiryuzan formation in the Yatsushiro (or Kuma) area of Kumamoto Prefecture is generally regarded as a representative of the Aritan series. It bears Nipponitrigonia plicata and Pterotrigonia hokkaidoana in addition to Toxoceras sp., Leptoceras sp. and Crioceratites sp. ex gr. C. duvali (Матsuмото, 
1954 ; KoBaYASHI and NAKano, 1959).

In the Kitakami mountains, Aritan marine pelecypods are found in the middle-upper part of the Oshima formation (=Yokonuma formation) at Oshima island, Kesennuma City, Miyagi Prefecture, and in the middle-upper part of the Ofunato group in the environs of Ofunato City, Iwate Prefecture.

The Oshima formation, which is probably Hauterivian-Barremian as indicated by the occurrence of Paracrioceras ishiwarai from the upper part, contains the following pelecypods :

Nanonavis (Nanonavis) yokoyamai (YABE and NAGAO) [Hy. 0004, 0009]

Gervillaria haradae (YокоYамA) [Hy. 0002]

Gervillia (Gervillia) forbesiana (D'ORBIGNY)*

Lopha (Arctostrea) carinata (LAMARCK) [Hy. 0003]

Gryphaea (s. l.) oshimensis sp. nov. [Hy. 0009]

Pterotrigonia pocilliformis (YокоYАMA) [Hy. 0002, 0003]

Astarte (Astarte) sp. cf. A. (A.) subsenecta YABE and NAGAO [Hy. 0012] Astarte (Astarte) sp. [Hy. 0012]

The Ofunato group including the Massaki group probably ranges from Kochian to Aritan, although index fossils have been scarcely found. According to Seki and IMAIZumi (1941) and ONUKI and MoRI (1961), many marine and brackish-water pelecypods occur in the Funagawara, Hijiochi and Takonoura formations of this group. Although my survey on the fauna is not yet completed, the following species have been identified in the collections of the University of Tokyo and the Tohoku University or are represented in the present collection:

[Funagawara formation]

Nanonavis (Nanonavis) yokoyamai (YABE and NAGAO)*

Eonavicula shinanoensis (YABE and NAGAO)*

Gervillia (Gervillia) forbesiana (D'ORBIGNY)*

Pterotrigonia pocilliformis (YoKoYama) *

Astarte (Astarte) subsenecta YABE and NAGA0*

Pachythaerus sp. cf. P. kagaharensis (YoKoYAMA)*

Costocyrena radiatostriata (YABE and NAGAO) [Hy. 0051]

Eomiodon sakawanus (KoBAYASHI and SUZUKI) [Hy. 0054]

Neomiodon sp. ef. N. otsukai (YABE and NAGA0) [Hy. 0054]

Paracorbicula sanchuensis (YABE and NAGAO) [Hy. 0054]

Panopea (Myopsis) plicata (SOWERBY)*

[Hijiochi formation]

Nanonavis (Nanonavis) yokoyamai (YABE and NAGA0)*

Plicatula sp.*

Lopha (Arctostrea) carinata (LAMARCK)*

Pterotrigonia pocilliformis (YoKoYAMA)*

Nipponitrigonia kikuchiana (YoKoYAMA)*

Ptychomya densicostata NaGAO [Hy. 0053]

Veniella sp.* [Hy. 0053]

In the northern Kitakami mountains the Kochian and Aritan series seem to 
be represented by the thick strata of the Rikuchu group, i.e. the Omoto, Harachiyama, Takinoshirisawa and Matsumaezawa formations in ascending order (ONUKI, HASE and SUZUKI, 1960). The brackish-water pelecypods of the Omoto formation recall me to the Kochian fauna, as noted before. A marine faunule including Pterotrigonia hokkaidoana was reported to occur from the Takinoshirisawa formation near Omoto of the Miyako area. The age of this faunule must be Aritan or thereabout in view of the stratigraphic position, though I have had no chance to observe the specimens.

Recently NAKAZAWA (1965) reported preliminarily the occurrence of a characteristic molluscan fauna including Bakevellia, Isognomon, Protocardia, Costocyrena and Filosina from the folded complex near the Ominé mine, northwest of Kamaishi, Iwate Prefecture. The age, as was suggested by him, is presumably Aritan if not Kochian**.

\section{3) Miyakoan pelecypod faunas}

Miyakoan pelecypod fossils are generally better preserved and more abundant as regards both numbers of species and individuals than Aritan ones. The Aritan deposits are mostly marine, while the Miyakoan (especially Upper Miyakoan) faunas comprise a considerable number of brackish-water species which occur commonly in some members of many sedimentary areas of Southwest Japan. The lower Miyakoan (K3a) roughly corresponds to the European Aptian, the upper Miyakoan $(\mathrm{K} 3 \beta)$ to the Albian, and the uppermost Miyakoan (K3 $\gamma$ ) or Infra-Gyliakian to the lowest Cenomanian (MAтsumoto, 1954, 1959, 1963). By the reason stated before (Part I, p. 228), the pelecypod faunas of the uppermost Miyakoan are not discussed here.

The "Kawarazawa formation" of the Sanchu area in the Kwanto mountains was generally regarded as Miyakoan. As suggested by ARAI et al. (1958) and TAKEI (1963), however, this formation, especially the fossiliferous part, seems to be correlative to the Aritan Ishido formation. In fact, all the pelecypods hitherto known from the "Kawarazawa formation" are identical with the species from the Ishido formation.

On the other hand the brackish-water molluscan beds of the "Shiroi formation" at Hachimanzawa and some other localities, which were formerly assigned to the Kochian series, are evidently younger than the marine fossil beds of the Ishido formation. The stratigraphy of the eastern part of this area was recently clarified to some extent by TAKEI (1963), who named the brackish-water beds the Sebayashi formation. Although at present there is no definite palaeontological evidence concerning the age, I provisionally regard the Sebayashi formation as a representative of the Miyakoan series, because similar brackish-water beds with the species of Costocyrena are also common in the Miyakoan series of the Outer Zone of Southwest Japan. The following pelecypods were collected from the brackish-water beds at Hachimanzawa, south of Kagahara, Nakazato village,

\footnotetext{
** See also Postscript IV.
} 
Gumma Prefecture. The same formation exposes also at the southeast of Koya in the western part of the Sanchu area, Nagano Prefecture.

Isognomon (Isognomon) sanchuensis (YABE and NAGAO) [Hy. 4005]

Liostrea sp. [Hy. 4006]

Nippononaia ryosekiana (SUzUKI) [Hy. 4006]**

Protocyprina sp. [Hy. 4006]

Costocyrena radiatostriata (YABE and NAGAO) [Hy. 4005]

The overlying Sanyama formation bears some marine pelecypods and cephalopods. Although TAKEI (1963) regarded it as a representative of the Gyliakian series, the fauna from the lower part of this formation recalls me to the Miyakoan one. As to the palaeontology and biostratigraphy of the Sanyama formation, much should be done in future.

In the Outer Zone of Southwest Japan, Miyakoan deposits are widely distributed in many sedimentary areas generally in close connection with the Aritan ones.

The Todai formation of the Akaishi mountains is considered to be Aritan or Miyakoan in age, since it bears Nipponitrigonia naumanni (YEHARA), Pterotrigonia pocilliformis (YoKOYAMA) and some other marine pelecypods (WAKIMIZU, 1899; YEHARA, 1923; MAEDA, 1962, 1964). A pachyodont pelecypod, Pachytraga japonica OKUBo was reported from the Shirane belt of the mountains (OKubo and Matsushima, 1959), but its age cannot be determined with precision.

The Nishihiro and Izeki formations of the Yuasa-Aritagawa area of Wakayama Prefecture are approximately Miyakoan, as recognized from the stratigraphic sequence. It is noteworthy that the Nishihiro formation contains some brackish-water pelecypods which appear at first sight similar to those of the Kochian fauna, as pointed out by MATSUMOTO (1947).

Bakevellia shinanoensis (YABE and NAGAO)

Liostrea sp. cf. L. ryosekiana (KoBAYASHI and SUZUKI)

Isodomella sp. cf. I. shiroiensis (YABE and NAGA0)

Besides the brackish-water species mentioned above, Nipponitrigonia kikuchiana, Pterotrigonia pocilliformis and Pterotrigonia hokkaidoana were reported from different beds of the same formation.

The Izeki formation, which probably passes laterally into the Nishihiro formation, bears the following pelecypods:

Bakevellia shinanoensis (YABE and NAGAO) [Ys. 1020]

Gervillia (Gervillia) forbesiana D'ORBIGNY*

Costocyrena sp. aff. C. radiatostriata (YABE and NAGAO) [Ys. 1020, Hy. 9006]

Tetoria (Paracorbicula) sp. [Hy. 9006]

** SUzuki (1941) described Unio (Nippononaia) ryosekiana from the "Ryoseki series of the Sanchu area or the Katsuuragawa basin". The new discovery of specifically identical specimens in a large float of black carbonaceous shale at loc. Hy. 4006, Hachimanzawa, suggests that Suzuki's original specimens were possibly collected also from the Sebayashi formation. These specimens were recently described in a separate paper (Hayami and Ichikawa, 1965, Trans. Proc. Pal. Soc. Japan, N. S., No. 60, 145-155, pl. 17). 
In the Katsuuragawa basin of Tokushima Prefecture, the Miyakoan is represented by the Hoji $(=$ Boji) formation and probably also by the main part of the Fujikawa formation. The Hoji formation is said to contain Cheloniceras sp. and Ancyloceras giganteum, but unfortunately these ammonites have not been allocated in the stratigraphic columns. Marine pelecypods, especially trigoniids, occur abundantly in the lower and upper parts of this formation at various localities such as Hoji, south of Fujikawa, south of Sakamoto and Mt. Kaseyama, and some cyrenoids are common in a brackish-water member at Hiura and Ochiai, which is embedded in the middle part of this formation together with some coal seems and plant-beds.

Nuculopsis (Palaeonucula) ishidoensis (YABE and NAGAO) [Hy. 5017]

Gervillia (Gervillia) forbesiana D'ORBIGNY [Hy. 5017]

Liostrea spp. [Hy. 5037]

Nipponitrigonia kikuchiana (YoKoYAMA) [Hy. 5019]

Nipponitrigonia plicata KoBAYASHI and NAKANO [Hy. 5019]

Nipponitrigonia naumanni (YEHARA) ${ }^{*}[?=$ Nipponitrigonia sakamotoensis (YEHARA) ]

Pterotrigonia pocilliformis (YокоYамA) [Hy. 5017, 5021, 5022, 5023]

Eomiodon sakawanus (KoBAYASHI and SUZUKI) [Hy. 5027, 5031]

Tetoria (Paracorbicula) sp. [Hy. 5027, 5031]

Isocyprina aliquantula (AMANo) [Hy. 5019]

Pelecypods are very rare in the overlying Fujikawa formation except for the basal part where Pterotrigonia pocilliformis forms a fossil bank. Although some species of Inoceramus have been reported from the "Fujikawa formation" in the eastern part of this basin (HIRAYAMA et al., 1956), it is questionable whether the fossil bed is correlative to the Fujikawa formation proper or belong to a certain younger sedimentary cycle. "Beudanticeras" shikokuense, which was reported from the main part of this formation by YABE (1927), and "Desmoceras kossmati", which was listed by NAKANO (1960), closely resemble Desmoceras (Pseudouhligella) dawsoni and may indicate an Upper Albian age instead of a Cenomanian age.***

Amano (1957a) described many marine pelecypods from the upper part of the Monobegawa group or the Hagino formation at Hagino in the Monobegawa area of Kochi Prefecture, which is at least in part referable to the lower Miyakoan.*** The fauna is composed of the following species (specific names revised on the basis of AMANo's and the present specimens) :

Eonavicula prolata (AMANO) [Hy. 6011]

Nemodon (?) sp. [Hy. 6011]

** According to Mr. I. NAKaI's oral communication and presentation at the 91st Meeting of the Palaeontological Society of Japan at Nagasaki, 25th of September, 1965.

*** The ammonites of the Hagino formatin are not yet described, but some specimens, which were collected by Mr. OGAWA and are preserved in the Kyushu University, indicate an Aptian age (Prof. T. MAtsumoto's oral communication). 
Cucullaea fujii sp. nov. [Hy. 6011]

Trigonarca obliquata AMANo [Hy. 6011]

Modiolus falcatus AmaNo [Hy. 6011]

Gervillaria sp. cf. G. haradae (Yокочама) [Ну. 6011]

Neithea (Neithea) amanoi sp. nov. [Hy. 6011]

Chlamys shikokuensis AmaNo [Hy. 6011]

Acanthotrigonia moriana (YEHARA) [Hy. 6011]

Nipponitrigonia naumanni (YEHARA)*

Pseudocardia amanoi sp. nov. [Hy. 6011]

Eriphyla (Miyakoella) sp. cf. E. (M.) miyakoensis (NAGAO) [Hy. 6011]

Opis (Opis) haginoensis Amano [Hy. 6011]

Pachythaerus sp. cf. P. kagaharensis (YoKoYAma) [Hy. 6011]

Protocardia sp. [Hy. 6011]

Laevicardium (?) corpulentum (AMANO) [Hy. 6011]

Scittila sp. cf. S. japonica HAYAMI [Hy. 6011]

Isocyprina aliquantula (AMANo) [Hy. 6011]

Panopea (Myopsis) sp. cf. P. (M.) plicata (Sowerby) [Hy.6011]

Pholadomya sp. aff. P. cornueliana D'ORBIGNY [Hy. 6011]

Pholadomya sp. [Hy. 6011]

Plectomya sp. [Hy. 6011]

In addition, the following species were reported to occur from the Upper Monobegawa subgroup of this area, although I have not yet ascertain the specific identification: Glycymeris sp., Bakevellia pseudorostrata (NAGAo), Gervillia (Gervillia) forbesiana D'ORBIGNY, Spondylus sp. aff. S. decoratus NAGAo, Lopha (Arctostrea) carinata (LAMARCK), "Exogyra" sp., Nipponitrigonia kikuchiana (YokоYамa) and Pterotrigonia pocilliformis (Yokoyama).

The Upper Monobegawa subgroup of the Sakawa basin of Kochi Prefecture contains Pterotrigonia pocilliformis (YoKoYama) and some other pelecypods, but reliable analysis of the fauna has not been achieved.

The Kikunotani formation in the Kurosegawa area of Ehime Prefecture contains Nipponitrigonia kikuchiana (YoKOYAMA), Nipponitrigonia naumanni (Yehara) and Pterotrigonia pocilliformis (Yokoyama), but I have not yet been able to observe the associated pelecypods.

As listed by NagaI and NaKano (1961), the Nigyu formation in the Mikame area of the same prefecture bears Glycymeris densilineata NAGA0, Nipponitrigonia kikuchiana (Yokoyama), Pterotrigonia hokkaidoana (Yehara), Astarte (Astarte) sp. cf. $A$. (A.) subsenecta YABE and NAGAo and some other pelecypods, although the material is too poorly preserved to be described. The age of these formations cannot be determined in detail, but is certainly Miyakoan if not Aritan.

As reported by FUJII (1954), the Haidateyama formation and its comparable strata in the western area of Usuki, Oita Prefecture, contains some marine pelecypods as listed below:

Parallelodon nipponicus (NAGAo) [U. 1005] 
Nanonavis (Nanonavis) yokoyamai (YABE and NAGAO) [U. 1005]

Cucullaea fujii sp. nov. [U. 1005]

Pinna sp. [U. 1005]

Neithea (Neithea) matsumotoi sp. nov. [U. 1005]

Pterotrigonia pocilliformis (YoKOYAMA) [U. 1005, Hy. 3003]

Pterotrigonia datemasamunei (YEHARA)*

Astarte (Astarte) subsenecta YABE and NAGAO [U. 3095]

Veniella (?) sp.

There is no known index fossil in the Haidateyama formation, but the age is at least in part upper Miyakoan, because this formation closely resembles the Yatsushiro formation in the general aspect of the lithology and fauna.

In the Kuma mountains of Kumamoto Prefecture, the lower part of the Miyakoan series is well represented by the Hinagu formation and the upper part by the Yatsushiro formation. Pelecypods are common in the two formations and have been listed by Matsumoto and Kanmera (1952) and Matsumoto (1954). Some species of Parahoplites, Acanthoplites, Colombiceras and Deshayesites were reported to occur in the lower part of the Hinagu formation, and Engonoceras sp. aff. E. stolleyi, Hoplites sp. cf. H. dentatus and Hamiticeras sp. aff. $H$. aequicostatum are said to occur in the Yatsushiro formation. The assemblages seem to indicate an Aptian age for the former and an Albian age for the latter. In the lowest part of the Hinagu formation a brackish-water member with some pelecypods occurs, and the middle part bears many marine pelecypods, as listed below:

Nuculana (s. l.) sacnhuensis YABE and NAGAO [Km. 1832]

Parallelodon sp. cf. P. nipponicus (NAGAo) [Km. 3134]

Pinna sp. cf. P. robinaldina D'ORBIGNY [Km. 1832]

Neithea (Neithea) kanmerai sp. nov. [Km. 3085c]

Plicatula kiiensis sp. nov. [Km. 3085c]

Nipponitrigonia kikuchiana (YoKoYAMA) [Km. 3134]

Pterotrigonia hokkaidoana (YEHARA) [Km. 3085a, 3134]

Pterotrigonia (Rinetrigonia) sp. [Km. 3134]

Astarte (Astarte) subsenecta YABE and NAGAO [Km. 3085c]

Costocyrena sp. cf. C. matsumotoi HAYAMI [Km. 1639b]

"Nakamuranaia chingshanensis" (GRABAU) [Km. 1639b]

The Yatsushiro formation is distributed along two belts in the Kuma mountains. It is mostly marine, but some brackish-water sediments are inserted in the middle part. The following pelecypods were collected from various horizons at Miyaji, south of Kohara, north of Shimofukami, south of Bisho and north of Nekodani :

Mesosaccella sp. [Km. 3096]

Malletia (Neilo?) higoensis sp. nov. [Km. 3096]

Nuculana (s. l.) sanchuensis YABE and NAGAo [Km. 3096]

Parallelodon nipponicus (NAGAO) [Km. 1843]

Nanonavis (Nanonavis) yokoyamai (YABE and NAGAo) [Km.3096, 3037, 
Hy. 1016]

Nanonavis (Nanonavis) sp. cf. $N$. (N.) yokoyamai (YABE and NAGA0)

[Hy. 1007]

Trigonarca sp. cf. T. obliquata AMANo

Pterinella shinoharai sp. nov. [Km. 3037, 1843, Hy. 1012]

Gervillaria haradae (YokoYama) [Hy. 1021, At. 828A]

Bakevellia pseudorostrata (NAGAO) [Km. 1843]

Gervillia (Gervillia) forbesiana D'ORBIGNY [Km. 3096, 3097, At. 828A]

Neithea (Neithea) matsumotoi sp. nov. [Km. 3037, Hy. 1001]

Entolium (?) yatsushiroense sp. nov. [Km. 1843]

Limatula sp. cf. L. nagaoi HAYAMI [Km. 1843]

Lopha (Arctostrea) carinata (LAMARCK) [Km. 1843, Hy. 1012]

Monia sp. cf. M. pseudotruncata (YABE and NAGAO) [Km. 3035]

Nipponitrigonia plicata KoBAYASHI and NAKANo [Km. 1843]

Rutitrigonia sanchuensis (NAKANO) [Km. 1843]

Pterotrigonia pocilliformis (YoKoYama) [Km. 1843, 3036, 3037, 3096, 3097,

Hy. 1007, 1012, 1021]

Acanthotrigonia sp. cf. A. dilapsa (YehaRA) [Km. 1843, 3096, 3097]

Pseudocardia sp.

Astarte (Astarte) subsenecta YABE and NAGAO [Km. 3037, At. 328]

Astarte (Freiastarte) sp. cf. A. (F.) subomalioides NAGAO [Km. 3037]

Astarte (Yabea) akatsui sp. nov. [At. 328]

Eriphyla (Eriphyla) minima sp. nov. [At. 328]

Anthonya sp. [Km. 1843]

Fimbria sp. [Km. 1843]

Nemocardium yatsushiroense sp. nov. [Km. 3037, Hy. 1012]

Laevicardium (?) ishidoense (YABE and NAGAO) [Km. 1843, At. 828A]

Veniella sp. aff. V. japonica NAGAO [Km. 3151]

Costocyrena matsumotoi sp. nov. [Km. 3035, Hy. 1017]

Tetoria (Paracorbicula) sp. [Hy. 1017]

Ptychomya densicostata NAGAO [Km. 1843]

Panopea (Myopsis) nagaoi sp. nov. [Km. 1843, 3097]

Pulsidis higoensis (Matsumoto)*

Pholadomya sp. indet. [Km. 1843]

Goniomya sp. indet. [Km. 3096]

Plectomya aritagawana sp. nov. [Km. 3113]

Plectomya sp. aff. P. anglica WooDs [Hy. 1016]

In the north Kitakami mountains the Miyakoan series is typified by the Miyako group. It is distributed at several narrow places bordering the coast between Miyako and Tanohata, Iwate Prefecture. Severe diastrophisms of the "Oshima phase", which were accompanied by folding and granitic intrusions, took place in upper Neocomian and/or lower Aptian times, and the Apto-Albian Miyako group abuts against the Aritan and earlier rocks of the Rikuchu group and also granitic rocks with a conspicuous unconformity. The Miyako group is 
mainly composed of calcareous sandstone and sandy shale, containing abundant and well-preserved neritic pelecypods at numerous localities and horizons (Yehara, 1915; YABE and NAGAO, 1926; NAGAO, 1932, 1934, 1943; HATAI, 1951). A detailed study on the sediments and fossils of this group is now being undertaken by HANAI, and the rich ammonites contained are also being investigated by OBATA**.

In the type section at Hiraiga of the Tanohata area and its northern coast, the Miyako group is composed of the following four sedimentary cycles:

4th cycle Aketo formation (=Akito sandstone)

3rd cycle unnamed formation (="Orbitolina sandstone")

2nd cycle Hiraiga formation (=Hiraiga sandstone)

1st cycle Tanohata formation (=Moshi sandstone + Tanohata shale)

$$
\text { disconformity }
$$

Raga conglomerate formation

$$
\text { - unconformity }
$$

Basement complex

The 1st and 2nd cycles carry the following ammonites (Shimizu, 1931; specific names revised by Matsumoto, 1954, 1959): Holcophylloceras caucasicum (SAYN), Melchiorites (?) matsushimensis (SHImız), Melchiorites yabei (SHIMIZU), Pseudohaploceras nipponicum SHIMIZU, Diadococeras nodosocostatiforme SHIMIZU, Cheloniceras subcornuerianum (SHIMIZU) and Parahoplites yaegashii SHIMIZu. These ammonites indicate an Aptian (probably upper Lower and lower Upper Aptian) age for the fossiliferous part of the two formations. In the Moshi and Miyako (Sakiyama) areas ammonites show also an Aptian age, and numerous fossil localities belonging to the "Moshi sandstone" and the "Hideshima sandstone" are correlative with the 1st and 2nd cycles of the type area.

The Tanohata and Hiraiga formations (and their equivalents) in the Tanohata, Moshi and Miyako areas, which are regarded as lower Miyakoan, contain the following pelecypods:

Mesosaccella insignis (NAGAO) [Hn. 4053, 4151]

Parallelodon nipponicus (NAGAO) [Hn. 0017]

Nanonavis (Nanonavis) yokoyamai (YABE and NAGAO) [Hn. 0012]

Cucullaea acuticarinata NAGAO [Hn. 0017, 0018, 0912, 0914, 0916]

Cucullaea transversa NAGAO [Hn. 0017, 0018]

Glycymeris (Hanaia) densilineata NAGAO [Hn. 0010, 0017, 0018, 0914, 0916, $1903,2065,4053$, etc.]

Glycymeris (Glycymerita?) haipensis sp. nov. [Hn. 0914, 4051]

Modiolus falcatus AMANo [Hn. 0220]

** I have been entrusted with the study of the Miyako pelecypods by Dr. T. HanaI, who kindly put his collection at my disposal. In this paper some of his unpublished results of his field survey are cited through his courtesy. The locality numbers and formation names cited are in agreement with those which will be used in his forthcoming publication. I have been informed by Dr. I. OBATA about the chronological relations of the Miyako group. My sincere thanks are due to these two persons for their kindness. 
Amygdalum ishidoense (YABE and NAGAO) [Hn. 0017, 0018]

Lecompteus sp. cf. L. guerangeri (D'ORBIGNY) [Hn. 4053]

Mytilus (?) sp.

Gervillaria haradae (YОКОҮАМА) [Hn. 0017]

Gervillaria miyakoensis (NAGAO) [Hn. 0017, 0920]

Bakevellia pseudorostrata (NAGA0) [Hn. 0017, 0018]

Gervillia (Gervillia) forbesiana D'ORBIGNY [Hn. 0017, 0018]

Isognomon (Mytiloperna) sp. [Hn. 0017, 0803]

Pinna sp. [Hn. 0018]

Atrina heiensis sp. nov. [Hn. 0018, 0220, etc.]

Neithea (Neithea) ficalhoi (CHOFFAT) [Hn. 0017, 0018, 0220, 0299, 0914, etc.]

Neithea (Neithella) sp. cf. N. (N.) atava (RöMER) [Hn. 0013, 0299]

Chlamys robinaldina (D'ORBIGNY) [Hn. 0017, 0103]

Prohinnites sp. cf. P. favrinus (PICTET and Roux)

Pectinella miyakoensis (NAGA0) [Hn. 0017, 0018]

Plicatula hanaii sp. nov. [Hn. 0017, 0803]

Spondylus decoratus NAGAO [Hn. 2065, etc.]

Plagiostoma (Plagiostoma) sanrikuense sp. nov. [Hn. 0017]

Plagiostoma (Acesta) goliathiforme sp. nov. [Hn. 0017, etc.]

Antiquilima ultima sp. nov. [Hn. 4053]

Ctenoides subrapa (NAGAO)

Limatula nagaoi sp. nov. [Hn. 0017, 0018, 0220]

Monia aptiana sp. nov. [Hn. 0017]

Liostrea sp. ex gr. L. cunabula (SEELEY) [Hn. 0803, ?4051]

Lopha (Lopha) nagaoi sp. nov. [Hn. 0017, 0802, 0803, 4024, etc.]

Lopha (Arctostrea) carinata (LAMARCK) [Hn. 0017, 0480, etc.]

Amphidonte (Amphidonte) subhaliotoidea (NAGAO) [Hn. 0017, 0023, 0310, 0802, 2058]

Amphidonte (Ceratostreon) yabei (NAGAO) [Hn. 0017, 0018, 0802, 0803, 0920, etc.]

Gryphaeostrea sp. ex gr. G. vesicularis (LAMARCK) [Hn. 0017]

Nipponitrigonia kikuchiana (YokoYama) [Hn. 0802, 0803, 0905, 4051, 4053, etc.]

Pterotrigonia hokkaidoana (YeHARA) [Hn. 0010, 0017, 0018, 0220, 0299, 0802, 0803, 0914, 0916, 0920, 1903, etc.]

Pterotrigonia yokoyamai (YEHARA) [Hn. 0017, 0018, etc.]

Pterotrigonia datemasamunei (YEHARA)*

Pterotrigonia kotoi (YeHARA)*

Myoconcha modesta sp. nov. [Hn. 0803]

Pseudocardia sp. cf. P. tenuicosta (SowerBy) [Hn. 2058]

"Cardita" (?) sp. [Hn. 2058]

Astarte (Astarte) semicostata NAGAO [Hn. 0017, 0018, 0914, 0916, 0920, etc.]

Astarte (Freiastarte) subomalioides NAGA0 [Hn. 0017, 0018, 0916, 4101, 
4051 , etc.]

Astarte (Nicaniella) minor NAGAO [Hn. 0017, 0018, 0914, 0916]

Eriphyla (Miyakoella) miyakoensis (NAGA0) [Hn. 0010, 0017, 0018, 0802, 0803, 0911, 0914, 4051, etc.]

Opis (Opis) nakanoi sp. nov.

Anthonya subcantiana NAGAO [Hn. 0017, 0018, 0220, etc.]

Lucinoma (?) kotoi (NAGA0) [Hn. 0017, 0018]

Protocardia (Globocardium) sphaeroidea (FoRBES) [Hn. 0001, 0017, 0220]

Protocardia hiraigensis sp. nov. [Hn. 0017]

Agapella (?) koikorobensis sp. nov. [Hn. 0803]

Nagaoella corrugata (NAGAO) [Hn. 0017, 0018, 1904, 2065, 4051, 0914, 0916]

Nagaoella sp. aff. N. corrugata (NAGAO) [Hn. 0914, 0916]

Panopea (Myopsis) plicata (SowerBy) [Hn. 0017, 0018, 0155, etc.]

Pholadomya miyamotoi NAGAO [Hn. 0017, 0018]

Pholadomya brevitesta NAGAO [Hn. 0006]

Pholadomya subpedelnalis NAGAO*

Pholadomya tuberculata sp. nov. [Hn. 0017, 0018]

Goniomya subarchiaci NAGA0 [Hn. 0016, 0017, 0018, 0220, 1903, etc.]

Cercomya gurgitis (PICTET and CAMPICHE) [Hn. 0018]

Thracia sp. [Hn. 0017]

Corimya (?) tanohatensis sp. nov.

"Teredo" matsushimaensis HATAI [Hn. 4154, 0017]

Praecaprotina yaegashii (YEHARA) [Hn. 0802, 0803, 4101, etc.]

The sediments belonging to the 3rd and 4th cycles of the Miyako group expose only in the type area. Hoplites sp. aff. H. dentatus, Desmoceras sp. and a few other ammonites occur from the upper part of the "Orbitolina sandstone" and the lower part of the Aketo formation, indicating a middle Albian age for the beds. The 3rd and 4 th cycles are therefore treated as the upper Miyakoan. The following pelecypods were collected or have been reported from the "Orbitolina sandstone" and the Aketo formation at the northeast of Raga, Tanohata village:

Nanonavis (Nanonavis) yokoyamai (YABE and NAGAO) [Hn.6203]

Cucullaea acuticarinata $\mathrm{NAGAO}^{*}$

Cucullaea transversa NAGAO*

Glycymeris (Hanaix) densilineata NAGAO [Hn. 6201, 6203]

Amygdalum ishidoense (YABE and NAGAO)*

Gervillaria miyakoensis (NAGAO) [Hn. 6203]

Gervillia (Gervillia) forbesiana D'ORBIGNY [Hn. 6203]

Pinna sp.*

Atrina heiensis sp. nov. [Hn. 6203]

Neithea (Neithea) nipponica sp. nov. [Hn. 0671, 6201, 6203]

Neithea (Neithea) ficalhoi (CHOFFAT) [Hn.6203]

Neithea (s. l.) aketoensis sp. nov. [Hn. 6201]

Chlamys sp. cf. C. subacuta (LAMARCK) [Hn. 6201] 


\author{
Pectinella miyakoensis (NAGAO)* \\ Ctenoides subrapa (NAGAO) [Hn. 6201] \\ Limatula nagaoi sp. nov.* \\ Lopha (Arctostrea) carinata (LAMARCK) [Hn. 6203] \\ Amphidonte (Ceratostreon) yabei (NAGAO) * \\ Amphidonte (Amphidonte) subhaliotoidea (NAGAo)* \\ Pterotrigonia pocilliformis (YoKoYAMA) [Hn. 6203] \\ Pterotrigonia datemasamunei (YEHARA)* \\ Astarte (Freiastarte) subomalioides NaGAo \\ Astarte (Nicaniella) minor NAGAO*
}

Eriphyla (Eriphyla) pulchella sp. nov. [Hn.6201, 6202, 6203]

Eriphyla (Miyakoella) miyakoensis (NAGA0) [Hn. 0671, 6201]

Anthonya subcantiana NAGAo [Hn. 6203]

Lucinoma (?) kotoi (NAGA0) [Hn. 6203]

Ptychomya densicostata NAGA0*

Nagaoella corrugata (NAGAo) [Hn.6201, 6203]

Panopea (Myopsis) plicata (SOWERBY) [Hn. 6203]

Pholadomya subpedelnalis NAGAo [Hn. 6203]

Goniomya subarchiaci NAGAo [Hn. 6201, 6202, 6203]

Cercomya gurgitis (PICTET and CAMPICHE) [Hn.6202]

Offadesma altissimum sp. nov. [Hn. 6203]

The Choshi formation in the Choshi area of Chiba Prefecture is referable to the Miyakoan series, since it bears Hypophylloceras aff. H. onoense, Ancyloceras choshiense and some other cephalopods. The following pelecypods have been reported previously or newly collected at Ashikajima and some other localities in this area:

Cucullaea sp. cf. C. acuticarinata NAGAO [Hy. 2003]

Isognomon (Isognomon) choshiensis sp. nov. [Hy. 2003]

Nipponitrigonia choshiensis MAEDA*

Pterotrigonia pocilliformis (Yокочама)*

Astarte (Astarte) costata YABE and NAGAo [Hy. 2001]

Panopea (Myopsis) sp. cf. P. (M.) plicata (SowERBY)*

In addition, the "Orbitolina sandstone" of the Lower Yezo group of Hokkaido contains two pachyodonts, Toucasia carinata orientalis and Praecaprotina yaegashii (YeHARA). It may be also Miyakoan in age, but no other pelecypod has been reported to occur in the group.

As reported by MATsumoto and HaRADA (1964), some pelecypods are known from the lower part of the Middle Yezo group in the Yubari area of Hokkaido. Desmoceras sp. cf. D. (Pseudouhligella) dawsoni, Mortoniceras (Cantabrigites) imaii (YABE and SHImizU), Anagaudryceras sacya (FoRBes) and some other ammonites indicate an Albian age for this part as well as Inoceramus anglicus WooDs and Inoceramus concentricus subsulcatus WILTSHIRE. The associated pelecypods, as listed by MATSUMOTO and HARADA (1964), are apparently more closely related to the uppermost Miyakoan and Gyliakian faunas than to the 
lower and upper Miyakoan faunas of Honshu. More precise study on the pelecypod fauna will be carried out on another occasion.

In the southern subzone of the Outer Zone of Southwest Japan, the Shimantogawa group is extensively distributed. In Shikoku it ranges actually from the Miyakoan to the Hetonaian. The Doganaro formation or the lowest part of this group is regarded as Miyakoan, as was interpreted by KATTO (1961). Although KOBAYASHI (1956) reported the occurrence of an Upper Jurassic trigoniid and KATTO (1961) listed some pelecypods of Gyliakian type, a marine faunule including Neithea spp., which was recently collected by Mr. K. Kawasawa and others from this formation at Kakureyashiki of Susaki City, indicates undoubtedly a Miyakoan age.

\section{Some remarks on the faunal characters}

\section{1) Faunal changes in the Lower Cretaceous of Japan}

About 50 species of pelecypods are distinguishable in the Aritan and about 130 species in the Lower and Upper Miyakoan formations of Japan, as listed in Table 2. About 30 species of the Aritan pelecypods range up into Miyakoan. Moreover, some of the Kochian brackish-water species are actually found in certain Miyakoan deposits such as the Nishihiro, Hoji, Yatsushiro and Sebayashi formations. This fact indicates that the life range of some "elements of the Ryoseki fauna" are much longer than formerly supposed. The stratigraphic distribution of those brackish-water pelecypods was probably much influenced by sedimentary conditions.

Berriasian marine pelecypods are not rare in Northeast Japan, and most of them range up from the Tithonian or earlier. No striking extinction took place at the end of the Upper Jurassic. The Aritan pelecypods of Japan are, however, quite different from the Berriasian and Upper Jurassic ones as regards the specific assemblage. Grammatodon and Myophorella became extinct, and Nanonavis, Trigonarca, Amygdalum, Pterinella, Gervillaria, Neithea, Rutitrigonia, Pterotrigonia, Pachythaerus, Anthonya, Costocyrena, Ptychomya, Scittila, Panopea and some other important genera seem to have appeared suddenly after the Kochian. No Valanginian index fossil has been found in Japan. The formations corresponding to this stage are mainly composed of brackish-water deposits of the Kochian series, probably because of an extensive regression of the sea. In Argentina and western Europe the extinction of pelecypod fauna was also not significant at the end of Jurassic, and a certain post-Berriasian extinction is expected in some areas, although it is not very clear whether the extinction was world-wide or not.

No marked difference is observed between the specific assemblages of the Aritan and Miyakoan (proper) pelecypod faunas. A great number of species appear to have started since the Lower Miyakoan, but they do not indicate the presence of a post-Neocomian extinction, because the Aritan fauna is much poorer than the Miyakoan one. In western Europe the Aptian pelecypod faunas are 
also closely related to the upper Neocomian ones.

On the other hand, the uppermost Miyakoan ( $\doteqdot$ lowest Cenomanian) pelecypods appear almost entirely different from those of the Miyakoan proper. The uppermost Miyakoan (or Infra-Gyliakian) is defined by the zone of Desmoceras kossmati and also by the occurrence of Graysonites lozoi (MATSUMoTo, 1959). The pelecypods from the lower part of the Gosyonoura group in west Kyushu and from the Middle Yezo group of Hokkaido differ almost completely from the upper Miyakoan species. Only a few species allied to Infra-Gyliakian and Gyliakian pelecypods are found in the Yatsushiro formation. As noted before, the pelecypod fauna of the lower part of the Middle Yezo group in the Yubari area is regarded as upper Albian (MATsumoto and HARAdA, 1964). The fauna bearing some species of Inoceramus is apparently more similar to the InfraGyliakian faunas than to the upper Miyakoan faunas of Honshu. Therefore, an extinction is expected during the upper Albian, although the migration and geographic separation of the faunas should be further examined.

One of the most striking phenomena in the faunal change of this stage was the sudden reappearance of Inoceramus. In Japan, the Inoceramidae were already flourishing in the Jurassic (HAYAMI, 1960a), but in the Lower Cretaceous they seem very rare. The apparent extinction of Parallelodon, Pterinella, Neithea, Costocyrena, Ptychomya and Goniomya is also noticeable. Astarte (s. l.) also declined after this stage. Upper Albian or post-Albian extinction presumably occurred also in western Europe, Gulf Coast and many other regions. The faunal changes, however, must have been much influenced also by the change of geographic and local sedimentary conditions, and it should be further investigated how closely they were connected with the evolution of pelecypods on a world-wide scale.

\section{2) Foreign elements in the Lower Cretaceous pelecypods of Japan}

As reflected in the specific identifications of Japanese Lower Cretaceous pelecypods made by many authors and myself, there are a number of elements in common with foreign countries, especially those of western Europe. In Jurassic times the pelecypods, which were surveyed by HAYAMI (1961), include many European and Tethyan affinities in addition to western Pacific endemic species. Cosmopolitan species are known mainly in the neritic facies of the Outer Zone of Southwest Japan and Abukuma and Kitakami mountains. A similar tendency is known as to the Lower Cretaceous pelecypod fauna.

DIETRICH (1936, p. 400) pointed out the presence of cosmopolitan species among the Miyakoan pelecypods described by NAGAO (1934), if the following emendations of specific identifications were accepted (emended names by DIETRICH in parentheses): Exogyra yabei NAGAO (=E. minos CoQUAND), Gervillia miyakoensis NAGAO (=Gervilleia aliformis SowERBY var.), Neithea morrisi (PICTET and RENEVIER), Protocardia sp. in NAGAO (=Cardium (Tendagurium) sphaeroideum Forbes), Ptychomya densicostata NAGAO (=P. robinaldina D'ORBIGNY), Panopea cf. gurgitis (BRONGNIART). Although I cannot always accept his emendation, 
the Aritan and Miyakoan pelecypods of Japan contain still many species which are identical with or hardly indistinguishable from typical forms of Europe, west Africa and some other countries.

So far as I can see, after comparing Japanese specimens with the illustrations of European specimens published by many authors and also with the collections of foreign fossils preserved in the Geological Institute, University of Tokyo and in the Department of Geology, Kyushu University, no marked difference is recognized as to the following species.

Nanonavis (Nanonavis) yokoyamai (YABE and NAGAO) is similar to Nanonavis securis (LEYMERIE) from the Neocomian of France, England and (?) Argentina, and also to Nanonavis (Nanonavis) carinata (SoWERBY) from the Lower Greensand of England and the Aptian of France.

Modiolus sp. aff. M. subsimplex D'ORBIGNY resembles the typical form from the upper Neocomian of France.

Lecompteus sp. cf. L. guerangeri D'ORBIGNY is almost identical with the typical form from the Upper Greensand of England and the Albian and Cenomanian of France.

Amygdalum ishidoense (YABE and NAGAO) is probably related to Modiolus rectior WOLLEMANN, from the Neocomian of Germany.

Pectinella shinoharai sp. nov. is probably intimate to Pterinella petersi ToulA from the Neocomian of Balkan, though specifically distinct.

Gervillaria haradae (YoKOYAMA) is somewhat similar to Gervillaria alaeformis (SowERBY) from the Lower Greensand of England and the Aptian of France. Similar species occur also from the Lower Cretaceous of Argentina, Mexico, Colombia S. A. and Nigeria.

Bakevellia pseudorostrata (NAGAO) resembles Bakevellia rostrata (SoWERBY) from the Upper Greensand of England and the Cenomanian of France.

Gervillia (Gervillia) forbesiana D'ORBIGNY is identical with the specimens from the Lower Greensand of England and the Aptian of France.

Pinna sp. cf. $P$. robinaldina D'ORBIGNY is almost indistinguishable from the typical form from the upper Neocomian and Aptian of France and the Lower Greensand of England.

Neithea (Neithea) nipponica sp. nov. resembles Neithea (Neithea) quinquecostata (SowERBY) from the Lower Greensand and Upper Greensand of England, the Albian of France and some other areas of western Europe, north Africa, the Near East and (?) Peru, although it is specifically separable.

Neithea (Neithea) amanoi sp. nov. resembles Neithea (Neithea) morrisi (Pictet and Renevier) from the Lower Greensand of England and the Aptian of France and also Neithea (Neithea) syriaca (CoNRAD) from the Aptian of the Near East.

Neithea (Neithea) ficalhoi (CHoFfat) is indistinguishable from the specimens from the Albian of Angola.

Neithea (Neithella) sp. cf. N. (N.) atava (RömER) is very close to the 
specimens of $N$. atava from the Lower Greensand of England, although there are some different opinions as to the concept of this species.

Chlamys robinaldina (D'ORBIGNY) is indistinguishable from the specimens from the Lower Greensand of England and the Aptian of France.

Chlamys sp. cf. C. subacuta (LAMARCK) is similar to the typical specimens from the Upper Greensand of England.

Prohinnites sp. cf. $P$. favrinus (PICTET and Roux) resembles the typical specimens from the Aptian of France and the Lower Greensand of England.

Liostrea sp. ex gr. L. cunabula (SEELEY) resembles the typical specimens from the Lower Greensand of England.

Lopha (Arctostrea) carinata (LAMARCK) seems to be a cosmopolitan species. It occurs also from the Lower Cretaceous of western Europe, north Africa, Gulf Coast, Mexico, Trinidad and Argentina.

Amphidonte subhaliotoidea (NAGA0) is similar to "Exogyra" haliotoidea, especially to the specimens from the Ootatoor group of southern India. Amphidonte (Ceratostreon) yabei (NAGAO) is probably related to "Exogyra minos" from the Lower Cretaceous of western Europe and South America.

Gryphaeostrea sp. ex gr. G. vesicularis (LAMARCK) is probably related to the typical form from the Aptian to Senonian of western Europe.

Pseudocardia sp. cf. P. tenuicosta (SOWERBY) resembles the typical specimens from the Lower Greensand of England.

Astarte (Astarte) semicostata NAGAO is closely related to Astarte cantabridgiensis WooDs, 1906, from the Lower Greensand of England.

Astarte (Yabea) shinanoensis YABE and NAGAO is fairly similar to Astarte bodei WollemanN from the Upper Neocomian of Germany.

Eriphyla (Miyakoella) miyakoensis (NAGAo) is probably intimate to Eriphyla (Miyakoella) upwarensis (WooDs) from the Lower Greensand of England.

Opis (Opis) nakanoi sp. nov. is somewhat similar to Opis haldonensis WooDs from the Upper Greensand and Opis neocomiensis D'ORBIGNY from the Lower Greensand of England.

Anthonya subcantiana NAGAo is similar to Anthonya cantiana WooDs from the Lower Greensand of England.

Protocardia sphaeroidea (FORBES) is in every way identical with the specimens from the Lower Greensand of England and the Aptian of France. Scittila japonica sp. nov. and Scittila sp. in the present paper are probably allied to Scittila nasuta CASEY (=Tellina carteroni in WooDs) from the Lower Greensand of England.

Panopea (Myopsis) plicata (Sowerby) is identical with the typical specimens from the Lower Greensand of England (=Panopea gurgitis in WooDs). Similar species are known from the Lower Cretaceous of Argentina, Trinidad and Gulf Coast region. 
Pholadomya miyamotoi NAGAo and Pholadomya sp. aff. P. cornueliana (D'ORBIGNY) are closely allied to Pholadomya cornueliana D'ORBIGNY from the Aptian of France and the Lower Greensand of England.

Cercomya gurgitis (PICTET and CAMPICHE) is identical with the typical specimens from the Aptian of France and the Lower Greensand of England.

Plectomya sp. aff. $P$. anglica Woons is fairly similar to the typical specimen of $P$. anglica from the Lower Greensand of England.

It is noticeable that the Aritan and Lower Miyakoan pelecypods of Japan include a considerable number of species identical with or closely allied to those of the upper Neocomian and Aptian faunas of western Europe. The Aptian pelecypods of the Miyako group are especially similar to the Lower Greensand fauna of England. The stratigraphic occurrence of the Lower Greensand fossils has recently been clarified by CASEY (1961) and further precise comparison will be possible zone by zone, when the stratigraphy and the index fossils of the Miyako group are described in detail.

It has been said that the biotope of the Lower Miyakoan including pachyodont pelecypods, nerinean gastropods, hermatypic corals, larger foraminifera, calcareous algae, etc., resembles that of the Urgonian, which represents the marginal facies of the ancient Mediterranean, but the similarity is mainly due to the similar physico-chemical conditions of sedimentary environment and not to synchronism. The specific assemblage of the lower Miyakoan pelecypods and gastropods is, in fact, more similar to that of the Lower Greensand than of the Urgonian.

Some Miyakoan pelecypods are closely related to those from the contemporary strata of Angola, Morocco, east Africa, Crimea, Caucasus, Syria, Lebanon, Attock and South India, if not identical with them. In order to justify the assumption of faunal communication between Japan and Europe (or between Japan and Indo-African province), it is necessary to investigate further the assemblages constituting the contemporaneous faunas in southeastern Asia. Our knowledge of this subject is, however, very insufficient at present.

Another faunal relation can be expected to have existed between Japan and the Pacific coast of Mexico and U.S. A. in Aptian-Albian times. As described by Allison (1955), the gastropods of the Alisitos formation of Baja California include many species in common with or allied to those of the Miyako group, which were described by NAGAO (1934). Similar resemblance can be expected among the associated pelecypods of that formation*.

There are a large number of contributions on the Lower Cretaceous pelecypods of the Gulf Coast region and South American cordillera. Although more precise comparison will depend upon the further integration of descriptions, the faunas of those regions are seemingly almost unrelated to those of the Japanese

* The pelecypods of the Alisitos formation remain undescribed, but the presence of some common or allied species was suggested in a list, which was kindly sent me by Prof. Edwin C. Allison of the San Diego State College. 
Table 2. List of Lower Cretaceous marine pelecypods from Japan

\begin{tabular}{|c|c|c|c|c|c|c|c|c|c|c|c|c|c|c|c|c|c|c|c|}
\hline \multirow{3}{*}{\multicolumn{3}{|c|}{$\begin{array}{l}\text { K1: Kochian }(\doteqdot \text { Berriasian }+ \text { Valanginian }) \\
\text { K2: Aritan }(\doteqdot \text { Hauterivian }+ \text { Barremian }+ \text { ? Lower Aptian }) \\
\text { K3: Miyakoan }(\doteqdot \text { Aptian }+ \text { Albian }+ \text { Lowest Cenomanian })\end{array}$}} & \multicolumn{6}{|c|}{ Northeast Japan } & \multicolumn{10}{|c|}{ Southwest Japan } & \multirow[t]{2}{*}{ Range } \\
\hline & & & \multicolumn{3}{|c|}{$\begin{array}{l}\text { Kita- } \\
\text { kami }\end{array}$} & \multicolumn{3}{|c|}{ 要 $\begin{array}{c}\text { Kwan } \\
\text { to }\end{array}$} & & \multirow[b]{2}{*}{ 蛋 } & \multicolumn{5}{|c|}{ Shikoku } & \multicolumn{3}{|c|}{ Kyushu } & \\
\hline & & & 尊 & $\mid \begin{array}{c}0 \\
\mathbf{3} \\
\mathfrak{z} \\
\vdots \\
\dot{t} \\
0 \\
0\end{array}$ & & & & & & & & & 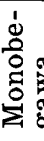 & & 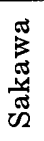 & $\begin{array}{l}\mathbf{z} \\
\mathbf{Z} \\
\mathbf{z}\end{array}$ & & & \\
\hline \multicolumn{2}{|c|}{ 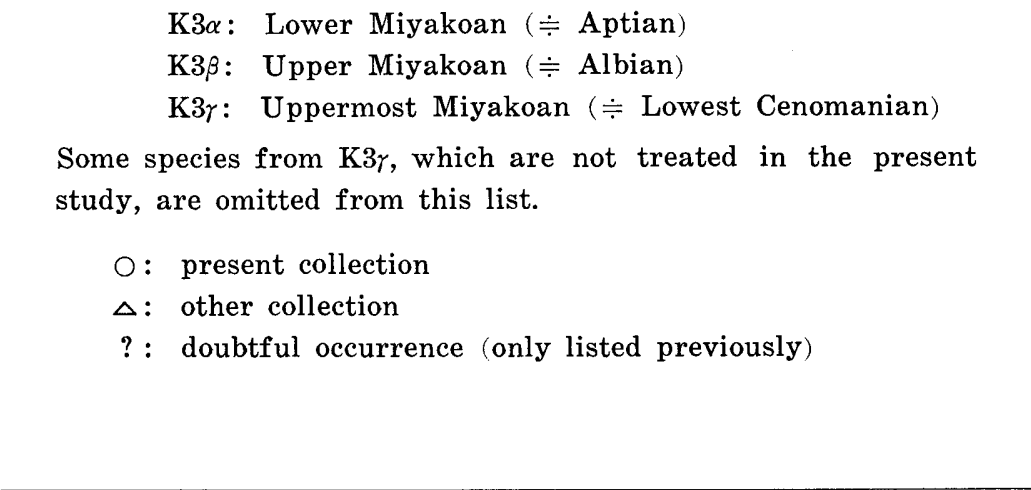 } & 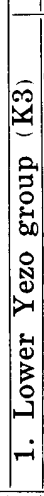 & 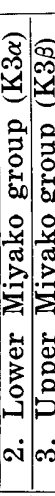 & 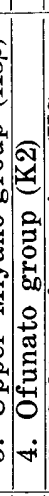 & 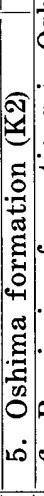 & & 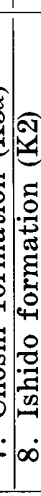 & 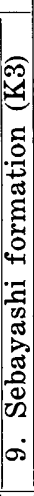 & 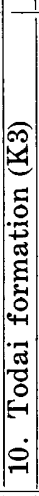 & 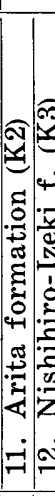 & 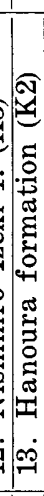 & 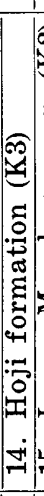 & 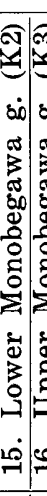 & \begin{tabular}{l|l} 
\\
3 \\
3
\end{tabular} & 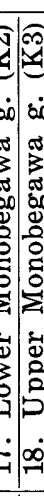 & 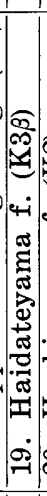 & 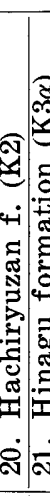 & 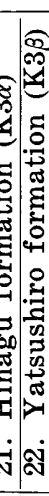 & \\
\hline \multirow{3}{*}{ Malletiidae } & 1. Mesosaccella insignis (NAGAo) & & $0 \Delta$ & & & & & & & & & & & & & & & & $\mathrm{K} 3 \alpha-\mathrm{K} 3 \beta$ \\
\hline & 2. Mesosaccella sp. & & & & & & & & & & & & & & & & & 0 & $\mathbf{K} 3 \beta$ \\
\hline & 3. Malletia (Neilo?) higoensis sp. nov. & & & & & & & & & & & & & & & & & 0 & $\mathrm{~K} 3 \beta$ \\
\hline Nuculidae & $\begin{array}{l}\text { 4. Nuculopsis (Palaeonucula) ishidoensis (YABE and } \\
\text { NAGAO) }\end{array}$ & & & & & & 0 & & & & 0 & $\Delta$ & & & & & & & $\mathrm{K} 2-\mathrm{K} 3$ \\
\hline Nuculanidae & 5. Nuculana (s. l.) sanchuensis YABE and NAGAO & & & & & & O & & & $?$ & 0 & & & & & & & 0 & $\mathrm{~K} 2-\mathrm{K} 3 \beta$ \\
\hline \multirow{2}{*}{$\begin{array}{l}\text { Parallelo- } \\
\text { dontidae }\end{array}$} & 6. Parallelodon nipponicus (NAGA0) & & 0 & & & & & & & 0 & & & & & & 0 & & 0 & $\mathrm{~K} 2-\mathrm{K} 3 \beta$ \\
\hline & 7. Parallelodon (Torinosucatella) kobayash?i (TAMURA) & & & & & $\Delta$ & & & & & & . & & & & & & & K1 \\
\hline
\end{tabular}




\begin{tabular}{|c|c|c|c|c|c|c|c|c|c|c|c|c|c|}
\hline & & $1|2| 3 \mid$ & $|4| 5 \mid$ & 6 & $7|8|$ & $9|10|$ & $111 \mid 12$ & $|13| 1$ & $4|15| 1$ & $16|17|$ & $18|19| 20$ & $21 \mid 22$ & range \\
\hline \multirow{4}{*}{$\begin{array}{l}\text { Parallelo- } \\
\text { dontidae }\end{array}$} & 8. Grammatodon takiensis KIMURA & & & $\Delta$ & & & & & & & & & K1 \\
\hline & 9. Grammatodon sp. & & & $\Delta \mid$ & & & & & & & & & K1 \\
\hline & 10. Nanonavis (Nanonavis) yokoyamai (YABE and NAGAO & Olo & $\Delta|O|$ & & 0 & & | & $\mid$ & & & & 0 & $\mathrm{~K} 2-\mathrm{K} 3 \beta$ \\
\hline & $\begin{array}{l}\text { 11. Nanonavis (Nanonavis) sp. cf. } N .(N .) \text { yokoyamai } \\
\text { (YABE and NAGAO) }\end{array}$ & & & & & & & & & & & 0 & $\mathrm{~K} 3 \beta$ \\
\hline \multirow{6}{*}{ Cucullaeidae } & 12. Cucullaea acuticarinafa NAGAO & $|\Delta| \Delta$ & & & $?$ & & & & & & & & $\mathrm{~K} 3 \alpha-\mathrm{K} 3 \beta$ \\
\hline & 13. Cucullaea transversa NAGAO & $|0| \Delta \mid$ & & & & & & & & & & & $\mathrm{K} 3 \alpha-\mathrm{K} 3 \beta$ \\
\hline & 14. Cucullaea fujii sp. nov. & & & & & & & & & $\Delta$ & $|0|$ & & $\mathrm{K} 3 \alpha-\mathrm{K} 3 \beta$ \\
\hline & 15. Trigonarca obsoleta YABE and NAGAO & & & & $|\Delta|$ & & & & & & & & $\mathrm{K} 2$ \\
\hline & 16. Trigonarca obliquata Amano & & & & & & & & & $\Delta$ & & & $\mathrm{K} 3 \alpha$ \\
\hline & 17. Trigonarca sp. cf. T. obliquata AMANo & & & & & & & & & & & 10 & $\mathrm{~K} 3 \beta$ \\
\hline \multirow{2}{*}{ Arcidae } & 18. Eonavicula prolata AMANo & & & & & & & & & $\Delta$ & & & $\mathrm{K} 3 \alpha$ \\
\hline & 19. Barbatia sp. & & & & & & & & $|0|$ & & & & $\mathrm{K} 2$ \\
\hline \multirow{2}{*}{$\begin{array}{l}\text { Glycymerid- } \\
\text { idae }\end{array}$} & 20. Glycymeris (Hanaia) densilineata NAGAO & 10 & & & & & & & & & & & $\mathrm{~K} 3 \alpha-\mathrm{K} 3 \beta$ \\
\hline & 21. Glycymeris (Glycymerita) haipensis sp. nov. & $|0|$ & & & & & & & & & & & $\mathrm{K} 3 \alpha$ \\
\hline \multirow{5}{*}{ Mytilidae } & 22. Modiolus falcatus AMANo & 0 & & & & & 0 & & & 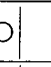 & & & $\mathrm{K} 2-\mathrm{K} 3 \alpha$ \\
\hline & 23. Modiolus sp. aff. M. subsimplex D'ORBIGNY & & & & & & $0 \mid$ & & & & & & $\mathrm{K} 2$ \\
\hline & 24. Amygdalum ishidoense (YABE and NAGAO) & $0 \mid ?$ & & & $\Delta$ & & & & & & & & $\mathrm{K} 2-\mathrm{K} 3 \alpha$ \\
\hline & 25. Lecompteus sp. cf. L. guerangeri (D'ORBIGNY) & $|0|$ & & & & & & & & & & & $\mathrm{K} 3 \alpha$ \\
\hline & 26. Mytilus sp. & 0 & & & & & & & & & & & $\mathrm{~K} 3 \alpha$ \\
\hline
\end{tabular}




\begin{tabular}{|c|c|c|c|c|c|c|c|c|c|c|c|c|c|}
\hline & & \begin{tabular}{l|l|l|l|l|l|l|}
1 & 2 & 3
\end{tabular} & \begin{tabular}{|l|l|l}
4 & 5
\end{tabular} & \begin{tabular}{|l|l|l}
5 & 6 & 7
\end{tabular} & 78 & $9|10| 11$ & $11 \mid 121$ & $13 \mid 14$ & $15 \mid 1$ & 617 & $18 \mid 192$ & $20|21| 22$ & range \\
\hline Pteriidae & 27. Pterinella shinoharai sp. nov. & & & & & lo & To & 0) & & & & & \begin{tabular}{l|l}
$\mathrm{K} 2-\mathrm{K} 3 \beta$ \\
$\mathrm{O}$
\end{tabular} \\
\hline \multirow{6}{*}{$\begin{array}{l}\text { Bakevelli- } \\
\text { idae }\end{array}$} & 28. Gervillaria haradae (YoKoYAMA) & 0 & $?$ & ? & 0 & & & & $?$ & $?$ & & & $\mathrm{~K} 2-\mathrm{K} 3 \beta$ \\
\hline & 29. Gervillaria miyakoensis (NAGAO) & lolo & & & & & & & & & & & $\mathrm{K} 3 \alpha-\mathrm{K} 3 \beta$ \\
\hline & 30. Bakevellia shinanoensis (YABE and NAGAO) & & & & & & 0 & & & & & & $\mathrm{~K} 1-\mathrm{K} 3$ \\
\hline & 31. Bakevellia pseudorostrata (NAGAO) & $|0|$ & & & & & & & & & & lo & $\mathrm{K} 3 \alpha-\mathrm{K} 3 \beta$ \\
\hline & 32. Bakevellia iwatensis sp. nov. & 0 & & & & & & & & & & & $\mathrm{~K} 3 \alpha$ \\
\hline & 33. Gervillia (Gervillia) forbesiana D'ORBIGNY & 10 & $?$ & & 10 & To & o & 0 & & & & Fo & $\mathrm{K} 2-\mathrm{K} 3 \gamma$ \\
\hline \multirow{4}{*}{$\begin{array}{l}\text { Isognomon- } \\
\text { idae }\end{array}$} & 34. Isognomon (Isognomon) choshiensis sp. nov. & & & o & & & & & & & & & $\mathrm{K} 3 \alpha$ \\
\hline & $\begin{array}{l}\text { 35. Isognomon (Isognomon) sanchuensis (YABE and } \\
\text { NAGAO) }\end{array}$ & & & & & $|0|$ & & & & & & & K3 \\
\hline & 36. Isognomon (Mytiloperna) sp. & $|0|$ & & & & & & & & & & & $\mathrm{K} 3 \alpha$ \\
\hline & 37. Isognomon (Melina) ichikawai sp. nov. & & & & $0 \mid$ & & & & & & & & $\mathrm{K} 2$ \\
\hline \multirow{3}{*}{ Pinnidae } & 38. Pinna sp. cf. P. robinaldina D'ORBIGNY & & & & $|0|$ & & & & $?$ & ? & & $|0|$ & $\mathrm{K} 2-\mathrm{K} 3 \alpha$ \\
\hline & 39. Pinna sp. & $0 \Delta$ & & & & & & & & & & & $\mathrm{K} 3 \alpha-\mathrm{K} 3 \beta$ \\
\hline & 40. Atrina heiensis sp. nov. & 10/0 & & & & & & & & & & & $\mathrm{K} 3 \alpha-\mathrm{K} 3 \beta$ \\
\hline \multirow{5}{*}{ Pectinidae } & 41. Neithea (Neithea) nipponica sp. nov. & 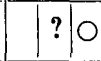 & & & & & & & & & & & ? K3 $\alpha-\mathrm{K} 3 \beta$ \\
\hline & 42. Neithea (Neithea) matsumotoi sp. nov. & & & & & & & & & & $|0|$ & To & $\mathrm{K} 3 \beta$ \\
\hline & 43. Neithea (Neithea) amanoi sp. nov. & & & & & & & & o & & & & $\mathrm{K} 3 \alpha$ \\
\hline & 44. Neithea (Neithea) ficalhoi (CHOFFAT) & olo & & & & & & & & & & & $\mathrm{K} 3 \alpha-\mathrm{K} 3 \beta$ \\
\hline & 45. Neithea (Neithea) kanmerai sp. nov. & & & & & O & & & & & & $|0|$ & $\mathrm{K} 2-\mathrm{K} 3 \alpha$ \\
\hline
\end{tabular}




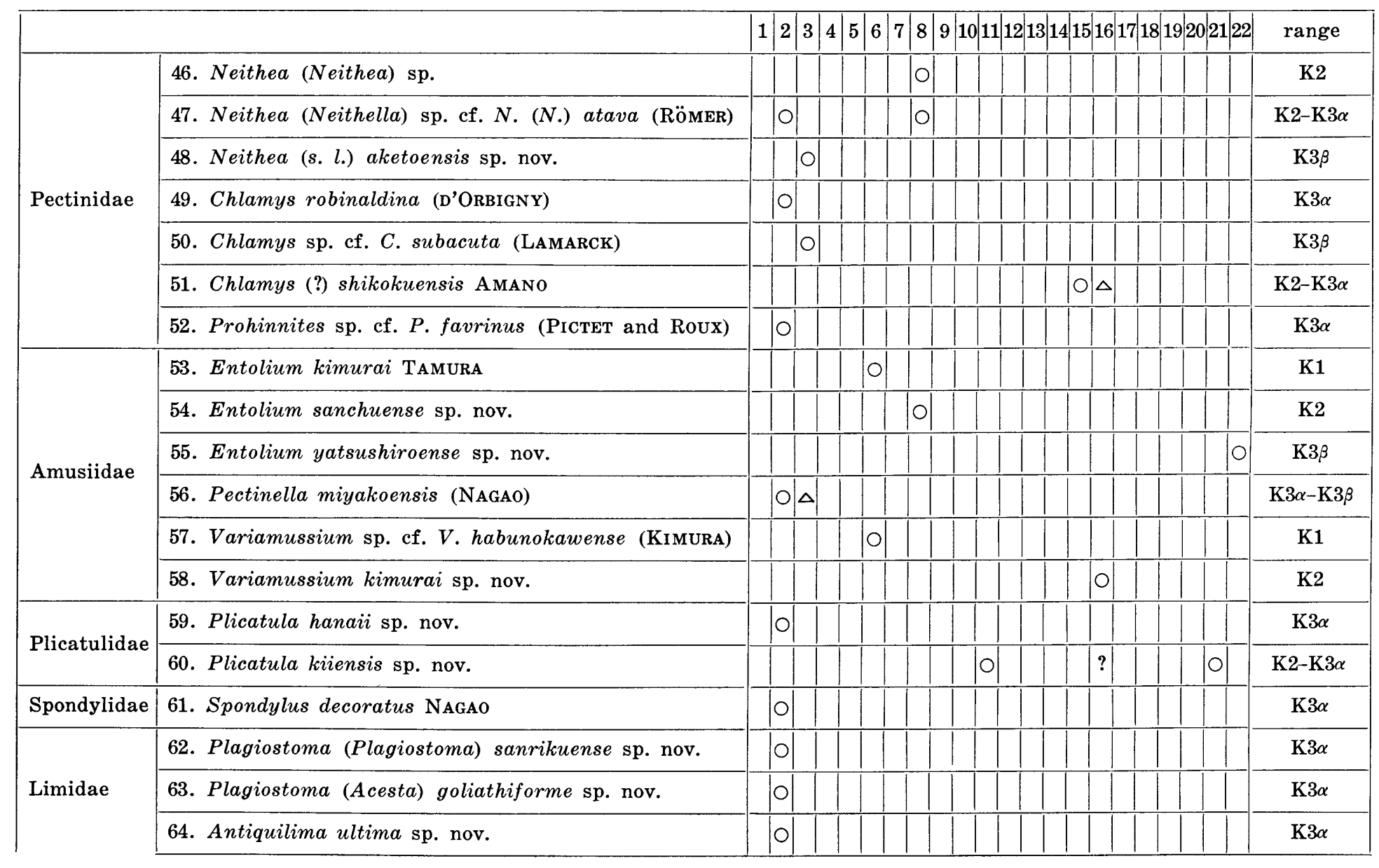




\begin{tabular}{|c|c|c|c|c|c|c|c|c|c|c|c|c|c|c|c|c|}
\hline & & & $2|3|$ & \begin{tabular}{|l|l|l}
4 & 5 \\
\end{tabular} & $|6|$ & & & 1011 & 1213 & 14 & $15 \mid 16$ & $6|17| 18$ & $18 \mid 19$ & 20 & 2122 & range \\
\hline \multirow{5}{*}{ Limidae } & 65. Ctenoides subrapa (NAGAO) & & $|0|$ & & & & & & & & & & & & & $\mathrm{K} 3 \alpha-\mathrm{K} 3 \beta$ \\
\hline & 66. Limatula akiyamae HAYAMI & & & & |o & & & & & & & & & & & K1 \\
\hline & 67. Limatula ishidoensis (YABE and NAGAO) & & & & & $|0|$ & & & & & & & & & & $\mathrm{K} 2$ \\
\hline & 68. Limatula nagaoi sp. nov. & o & $|\Delta|$ & & & & & & & & & & & & lo & $\mathbf{K} 3 \alpha-\mathbf{K} 3 \beta$ \\
\hline & 69. Limatula sp. cf. L. tombeckiana (D'ORBIGNY) & o & $\mid$ & & & & & & & & & & & & & $\mathbf{K} 3 \alpha$ \\
\hline \multirow{3}{*}{ Anomiidae } & 70. Monia pseudotruncata (YABE and NAGAO) & & & & & & & & & & & & & & & $\mathrm{K} 1$ \\
\hline & 71. Monia sp. cf. M. pseudotruncata (YABE and NAGAo) & & & & & & & & & & & & & & lo & $\mathbf{K} 3 \beta$ \\
\hline & 72. Monia aptiana sp. nov. & c & $\mid$ & & & & & & & & & & & & & $\mathbf{K} 3 \alpha$ \\
\hline \multirow{7}{*}{ Ostreidae } & 73. Liostrea sp. ex gr. L. cunabula (SEELEY) & 0 & 0 & & & & & & & & & & & & & $\mathrm{~K} 3 \alpha$ \\
\hline & 74. "Ostrea" ryosekiana KoBAYASHI and SUzUKI & & & & & & & & $|0|$ & & & & & & & $\mathrm{K} 1-\mathrm{K} 3$ \\
\hline & 75. Lopha (Lopha) nagaoi sp. nov. & O & | & & & & & & & & & & & & & $\mathrm{K} 3 \alpha$ \\
\hline & 76. Lopha (Arctostrea) carinata (LAMARCK) & & $0 \mid 0$ & o & & o & & & lo & & $\Delta$ & & o & & lo & $\mathrm{K} 2-\mathrm{K} 3 \beta$ \\
\hline & 77. Amphidonte (Amphidonte) subhaliotoidea (NAGAo) & & $0|\Delta|$ & & & & & & & & & & & & & $\mathrm{K} 3 \alpha-\mathrm{K} 3 \beta$ \\
\hline & 78. Amphidonte (Ceratostreon) yabei (NAGAO) & c & 0 & & & & & & & & & & & & & $\mathrm{~K} 3 \alpha$ \\
\hline & 79. Gryphaea (s. l.) oshimensis sp. nov. & & & o & ) & & & & & & & & & & & K2 \\
\hline \multirow{4}{*}{ Trigoniidae } & 80. Nipponitrigonia kikuchiana (YокоҮАмA) & & $\mid ?$ & $|?|$ & & $\Delta$ & & $|\Delta|$ & & $|0|$ & & & $?$ & & $?$ ? & $\mathrm{K} 2-\mathrm{K} 3 r$ \\
\hline & 81. Nipponitrigonia plicata KOBAYASHI and NAKANO & & & & & O & & & & $|\Delta|$ & & & & $|\Delta|$ & $\Delta$ & $\mathrm{K} 2-\mathrm{K} 3 \beta$ \\
\hline & 82. Nipponitrigonia naumanni (YEHARA) & & & & & & & $\Delta$ & & $|0|$ & & $\Delta|\Delta|$ & & & & $\mathrm{K} 2-\mathrm{K} 3$ \\
\hline & 83. Nipponitrigonia choshiensis MAEDA & & & & & $\Delta \mid$ & & & & & & & & & & $\mathbf{K} 3 \alpha$ \\
\hline
\end{tabular}




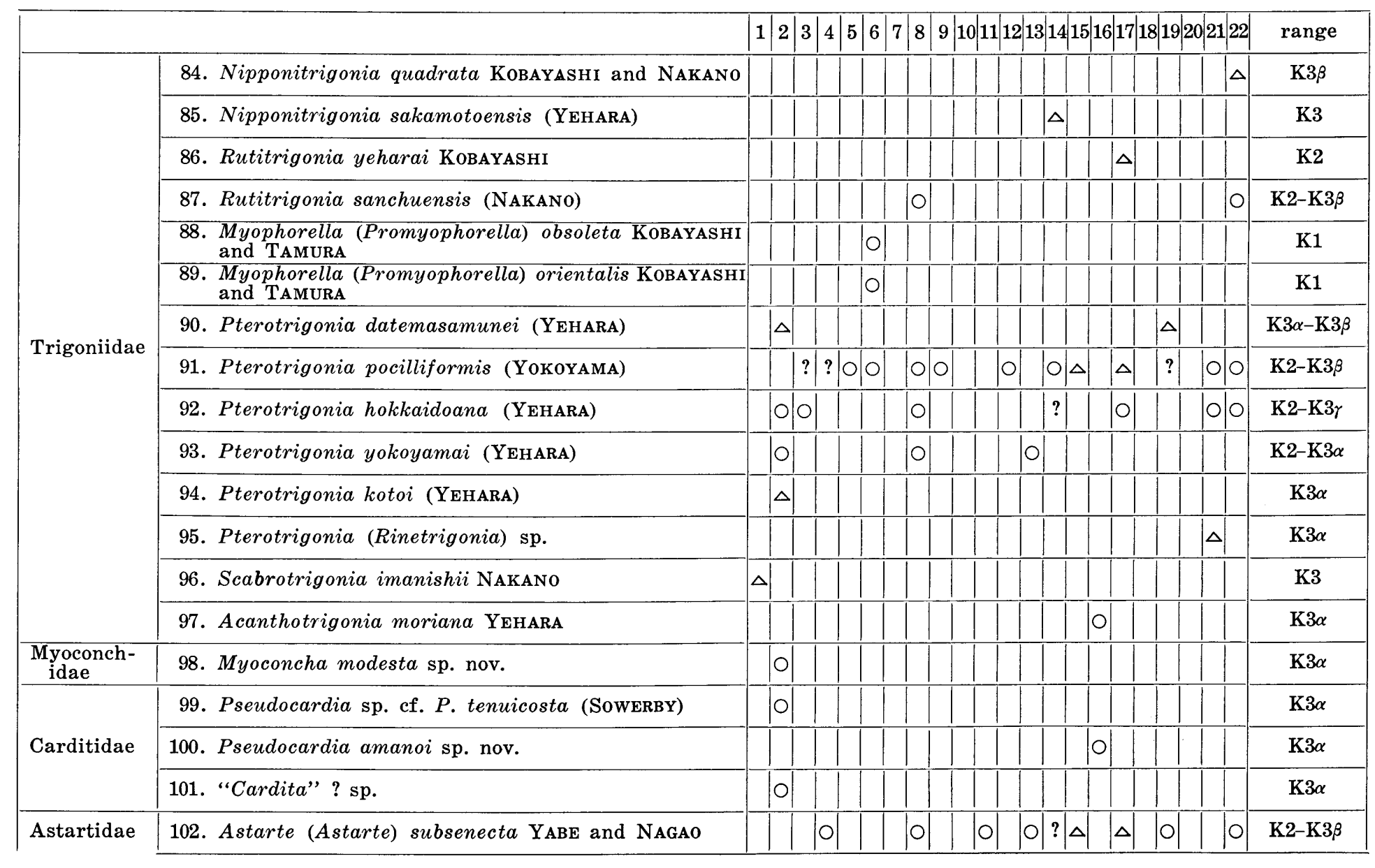




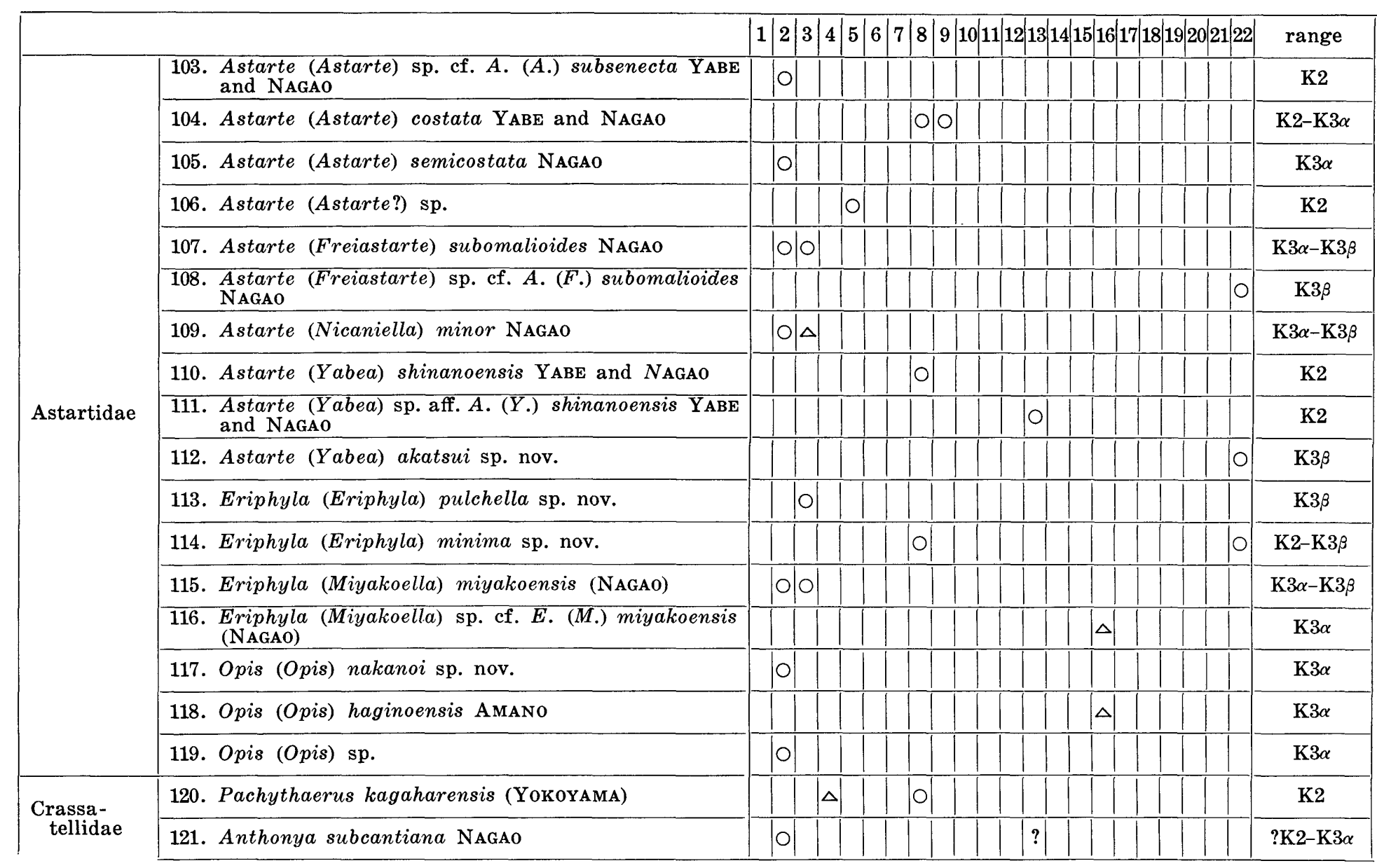




\begin{tabular}{|c|c|c|c|c|c|c|c|c|c|c|c|c|c|}
\hline \multirow{2}{*}{$\begin{array}{l}\text { Crassa- } \\
\text { tellidae }\end{array}$} & \multirow{2}{*}{ 122. Anthonya sp. aff. A. subcantiana NAGAO } & \multirow{2}{*}{\multicolumn{2}{|c|}{ 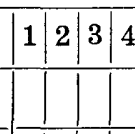 }} & \multirow{2}{*}{\begin{tabular}{|l|l|}
4 & 5 \\
1 & 1 \\
\end{tabular}} & \multirow{2}{*}{\begin{tabular}{|l|l|}
6 & 7 \\
1 & 1 \\
\end{tabular}} & \multicolumn{7}{|c|}{$8|9| 10|11| 12|13| 14|15| 16|17| 18|19| 20|21| 22$} & \multirow{2}{*}{\begin{tabular}{|c|} 
range \\
$\mathrm{K} 2$ \\
\end{tabular}} \\
\hline & & & & & & 10 & & & & & & & \\
\hline \multirow{2}{*}{ Lucinidae } & 123. Lucinoma (?) kotoi (NAGAO) & $|0| c$ & & & & & & & & & & & $\mathrm{~K} 3 \alpha-\mathrm{K} 3 \beta$ \\
\hline & 124. Lucinoma (?) sp. & & & & & & 0 & & & & & & $\mathrm{~K} 2$ \\
\hline Fimbriidae & 125. Fimbria sp. & & & & & & & & & & & 0 & K3 $\beta$ \\
\hline \multirow{5}{*}{ Cardiidae } & 126. Protocardia (Globocardia) sphaeroidea (FoRBES) & 0 & & & & & & & & & & & $\mathrm{~K} 3 \alpha$ \\
\hline & 127. Protocardia hiraigensis sp. nov. & $|0|$ & & & & & & & & & & & $\mathrm{K} 3 \alpha$ \\
\hline & 128. Nemocardium yatsushiroense sp. nov. & & & & & & & & & & & 10 & $\mathrm{~K} 3 \beta$ \\
\hline & 129. Laevicardium (?) ishidoense (YABE and NAGAO) & & & & & $\Delta$ & & & & & & 10 & K2-K3 $\beta$ \\
\hline & 130. Laevicardium (?) corpulentum (AMANo) & & & & & & & & & $|0|$ & & & $\mathrm{K} 3 \alpha$ \\
\hline \multirow{2}{*}{ lcanotiidae } & 131. Scittila japonica sp. nov. & & & & & & & $|0|$ & & $|\Delta|$ & & & $\mathrm{K} 2-\mathrm{K} 3 \alpha$ \\
\hline & 132. Scittila sp. & & & & & & & 0 & & & & & $\mathrm{~K} 2$ \\
\hline \multirow{7}{*}{$\underset{\text { idae }}{\text { Neomiodont- }}$} & 133. Costocyrena matsumotoi $\mathrm{sp}$. nov. & & & & & & & & & & & $? \mid 0$ & ? $\mathrm{K} 3 \alpha-\mathrm{K} 3 \beta$ \\
\hline & 134. Costocyrena radiatostriata (YABE and NAGAO) & & 0 & & & & 0 & & & & & & K2-K3 \\
\hline & $\begin{array}{l}\text { 135. Costocyrena sp. aff. C. radiatostriata (YABE and } \\
\text { NAGAO) }\end{array}$ & & & & & & & 0 & & & & & K3 \\
\hline & 136. Eomiodon sakawanus (KoBAYASHI and SUZUKI) & & 0 & & & & & & 0 & & & & $\mathrm{~K} 1-\mathrm{K} 3$ \\
\hline & 137. Protocyprina naumanni (NEUMAYR) & & & & & & & $?$ & & $|0|$ & & & $\mathrm{K} 1-$ ? K2 \\
\hline & 138. Protocyprina sp. & & & & & O & 0) & & & & & & K3 \\
\hline & 139. Neomiodon otsukai (YABE and NAGAO) & & $|0|$ & & & & & & & & & & $\mathrm{K} 1-\mathrm{K} 2$ \\
\hline Arcticidae & 140. Isocyprina aliquantula (AMANo) & & & & & ? & & $?$ & & 0 & & & $\mathrm{~K} 3 \alpha$ \\
\hline
\end{tabular}




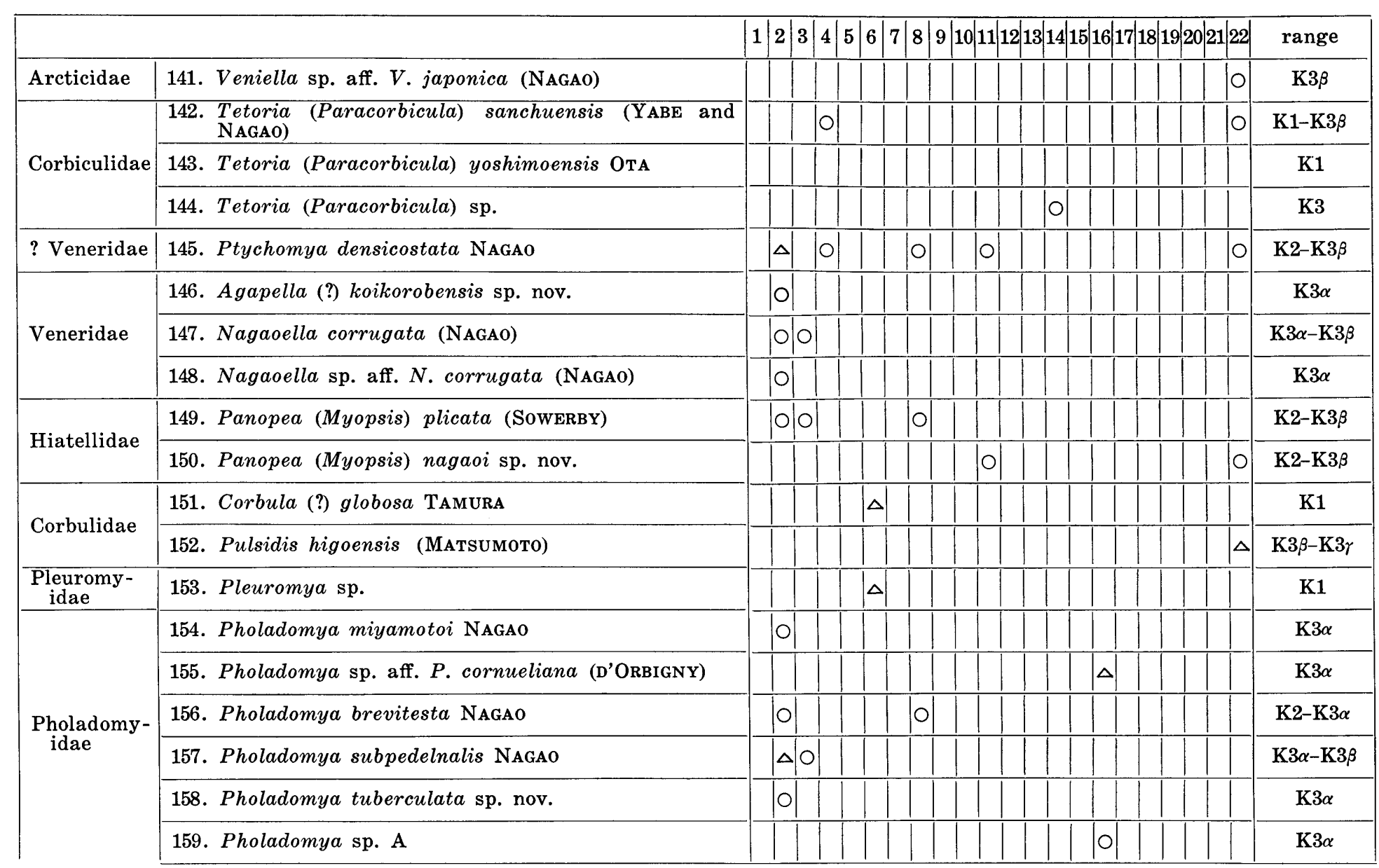




\begin{tabular}{|c|c|c|c|c|c|c|c|c|c|c|c|c|c|c|}
\hline & & 1 & $2 \mid 3$ & 4 & 5 & 6 & $7 \longdiv { 8 }$ & \begin{tabular}{|l|l|l|l|}
9 & 10 & 11 \\
\end{tabular} & $12|13|$ & $3|14| 15|16|$ & \begin{tabular}{|c|c|c|}
6 & 18 \\
17 & 0
\end{tabular} & $8|19| 20$ & $0|21| 22$ & range \\
\hline \multirow{3}{*}{$\begin{array}{l}\text { Pholadomy - } \\
\text { idae }\end{array}$} & 160. Pholadomya sp. B & & & & & & & & $|0|$ & & & & 0 & $\mathrm{~K} 2-\mathrm{K} 3 \beta$ \\
\hline & 161. Goniomya subarchiaci NAGAo & & 0 & & & & & & & & & & & $\mathrm{~K} 3 \alpha-\mathrm{K} 3 \beta$ \\
\hline & 162. Goniomya sp. & & & & & & 0 & & & & & & 0 & $\mathrm{~K} 2-\mathrm{K} 3 \beta$ \\
\hline \multirow{3}{*}{ Laternulidae } & 163. Cercomya gurgitis (Pictet and CAMPICHe) & & 0 & & & & & & & $?$ & & & & $\mathrm{~K} 3 \alpha-\mathrm{K} 3 \beta$ \\
\hline & 164. Plectomya aritagawana sp. nov. & & & & & & & $|0|$ & $|0|$ & & & & 0 & $\mathrm{~K} 2-\mathrm{K} 3 \beta$ \\
\hline & 165. Plectomya sp. aff. $P$. anglica Woods & & & & & & & & & & & & 0 & $\mathrm{~K} 3 \beta$ \\
\hline $\begin{array}{l}\text { Periplomat- } \\
\text { idae }\end{array}$ & 166. Offadesma altissimum sp. nov. & & 10 & & & & & & & & & & & $\mathbf{K} 3 \beta$ \\
\hline \multirow{2}{*}{ Thraciidae } & 167. Thracia sp. & & O & & & & & & & & & & & $\mathrm{K} 3 \alpha$ \\
\hline & 168. Corimya (?) tanohatensis sp. nov. & & $\mathrm{O}$ & & & & & & & & & & & $\mathrm{K} 3 \alpha$ \\
\hline Teredinidae & 169. "Teredo" matsushimaensis HATAI & & ) & & & & & & & & & & & $\mathrm{K} 3 \alpha$ \\
\hline \multirow{3}{*}{ Hippuritidae } & 170. Praecaprotina yaegashii (YEHARA) & & 0 & & & & & & & & & & & $\mathrm{~K} 3 \alpha$ \\
\hline & 171. Toucasia carinata orientalis NAGAo & 0 & & & & & & & & & & & & K3 \\
\hline & 172. Pachytraga japonica ОкUво & & & & & & & & & & & & & ? K3 \\
\hline
\end{tabular}


Aritan and Miyakoan except for a few cosmopolitan species.

In Alaska and British Columbia and along the Pacific coast of United States, Buchia- (=Aucella-) and Aucellina-bearing faunas prospered in early Cretaceous times and suggested an intimate connection with the Arctic province. Arctic elements cannot be found in the Aritan and Miyakoan pelecypods here discussed, but "Aucella" spp., recently discovered by TeraokA et al. (1962) from the Saroma group of a Late Jurassic or early Cretaceous age in northeast Hokkaido may be an exception.

\section{Locality Guide}

In this article main registered localities of Lower Cretaceous pelecypods concerning the present study are listed. The geographic and stratigraphic positions, age, lithology, fossil assemblage and collector(s) are briefly mentioned.

1. Tanohata area, Shimohei County, Iwate Prefecture (岩手県下閉伊郡田野畑村) $141^{\circ} 57^{\prime} \mathrm{E}, 39^{\circ} 56^{\prime} \mathrm{N}$ (Fig. 1)

Hn. 0001

Location: Tokuzo (トクソウ), southern coast of Hiraiga (平井賀) inlet

Str. position: middle part of the Hiraiga formation (lower Miyakoan)

Lithology: fine grey calcareous sandstone

Fossils: Protocardia (Globocardium) sphaeroidea (FORBES)

Collector: HANAI

Hn. 0006

Location: west of Tokuzo, southern coast of Hiraiga inlet

Str. position: upper part of the Tanohata formation (lower Miyakoan)

Lithology: grey sandy shale

Fossils: Pholadomya brevitesta NAGAo, Corimya (?) tanohatensis sp. nov. [boulder]

Collectors: HANAI and HAYAMI

Hn. 0010

Location: Tokuzo, southern coast of Hiraiga inlet

Str. position: lower part of the Hiraiga formation (lower Miyakoan)

Lithology: fine grey calcareous sandstone

Fossils: Glycymeris (Hanaia) densilineata NAGAO, Pterotrigonia hokkaidoana (YeHARA), Eriphyla (Miyakoella) miyakoensis (NAGAO)

Collectors: HaNaI and Hayami

Hn. 0012

Location: Tokuzo, southern coast of Hiraiga inlet

Str. position: lower part of the Hiraiga formation (lower Miyakoan)

Lithology: grey sandy shale

Fossils: Nanonavis (Nanonavis) yokoyamai (YABE and NAGAo)

Collector: HAYAMI

Hn. 0013

Location: Tokuzo, southern coast of Hiraiga inlet

Str. position: lower part of the Hiraiga formation (lower Miyakoan)

Lithology: fine dirty calcareous sandstone

Fossils: Neithea (Neithella) sp. cf. $N$. (N.) atava (RöMER)

Collector: HAYAMI

Hn. 0016

Location: Tokuzo, southern coast of Hiraiga inlet

Str. position: lower part of the Hiraiga formation (lower Miyakoan) 


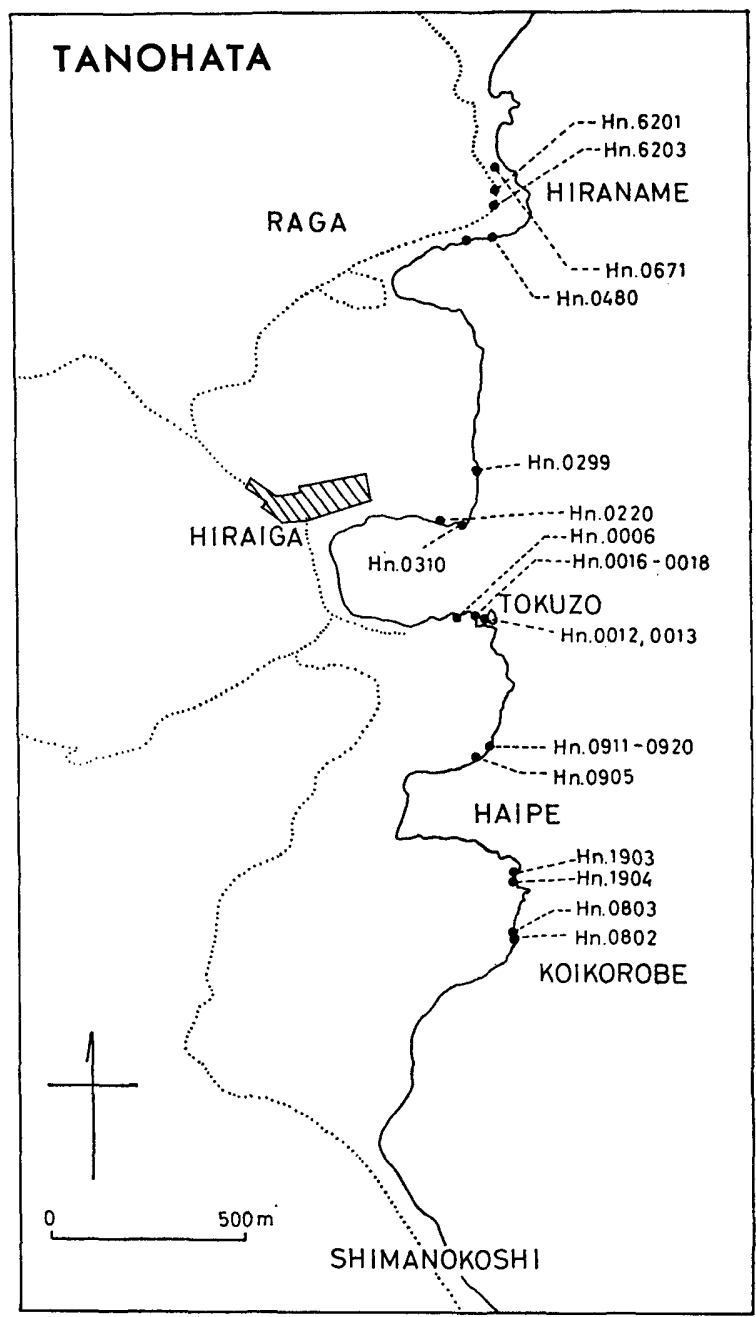

Fig. 1. Map showing the fossil localities in the Tanohata area.

Lithology: grey sandy shale

Fossils: Pectinella miyakoensis (NAGAo), Limatula nagaoi sp. nov.

Collector: HAYAMI

Hn. 0017

Location: Tokuzo, southern coast of Hiraiga inlet

Str. position: lower part of the Hiraiga formation (lower Miyakoan)

Lithology: fine grey calcareous sandstone

Fossils: Parallelodon nipponicus (NAGAo), Cucullaea acuticarinata NaGAo, Cucullaea transversa NAGAO, Glycymeris (Hanaia) densilineata NAGAO, Amygdalum ishidoense (YABE and NAGAO), Gervillaria haradae (YoKoYAMA), Gervillaria miyakoensis (NAGAO), Bakevellia pseudorostrata (NAGAO), Bakevellia iwatensis sp. nov., Gervillia (Gervillia) forbesiana D'ORBIGNY, Isognomon (Mytiloperna) sp., Neithea (Neithea) ficalhoi (Choffat), Chlamys robinaldina (D'ORBIGNY), Pectinella miyakoensis (NAGAo), Plicatula hanaii sp. nov., Plagiostoma (Plagio- 
stoma) sanrikuense sp. nov., Plagiostoma (Acesta) goliathiforme sp. nov., Limatula nagaoi sp. nov., Monia aptiana sp. nov., Lopha (Lopha) nagaoi sp. nov., Lopha (Arctostrea) carinata (LAMARCK), Amphidonte (Amphidonte) subhaliotoidea (NAGAO), Amphidonte (Ceratostreon) yabei (NAGAo), Gryphaeostrea sp. ex gr. G. vesicularis (LAMARCK), Pterotrigonia hokkaidoana (YEHARA), Pterotrigonia yokoyamai (YEHARE), Astarte (Astarte) semicostata NAGA0, Astarte (Freiastarte) subomalioides NaGAO, Eriphyla (Miyakoella) miyakoensis (NAGA0), Astarte (Nicaniella) minor NAGA0, Anthonya subcantiana NAGA0, Lucinoma (?) kotoi (NAGAo), Protocardia hiraigensis sp. nov., Protocardia (Globocardium) sphaeroidea (FoRBES), Nagaoella corrugata (NAGAo), Panopea (Myopsis) plicata (Sowerby), Pholadomya miyamotoi NAGAo, Pholadomya tuberculata sp. nov.,Goniomya subarchiaci NAGAo, Theracia sp., "Teredo" matsushimaensis HATAI, Opis (Opis) sp.

Collectors: Hanai, Obata, Nakano and Hayami

Hn. 0018

Location: Tokuzo, southern coast of Hiraiga inlet

Str. position: lower part of the Hiraiga formation (lower Miyakoan)

Lithology: fine grey calcareous sandstone

Fossils: Cucullaea acuticarinata NAGA0, Cucullaea transversa NAGA0, Glycymeris (Hanaia) densilineata Nagao, Amygdalum ishidoense (YABE and NAGAo), Bakevellia pseudorostrata (NAGAo), Bakevellia iwatensis sp. nov., Gervillia (Gervillia) forbesiana D'OrbignY, Atrina heiensis sp. nov., Pinna sp., Neithea (Neithea) ficalhoi (Choffat), Pectinella miyakoensis (NAGAO), Limatula nagaoi sp. nov., Amphidonte (Ceratostreon) yabei (NAGAO), Pterotrigonia hokkaidoana (YAhara), Pterotrigonia yokoyamai (YetARA), Astarte (Astarte) semicostata NagAo, Astarte (Freiastarte) subomalioides NAGAO, Astarte (Nicaniella?) minor NAGAO, Eriphyla (Miyakoella) miyakoensis (NAGA0), Anthonya subcantiana NAGA0, Lucinoma (?) kotoi (NAGA0), Nagaoella corrugata (NAGAo), Panopea (Myopsis) plicata (Sowerby), Pholadomya miyamotoi NagAo, Pholadomya tuberculata sp. nov., Goniomya subarchiaci NaGA0, Cercomya gurgitis (Pictet and CAMPiche)

Collectors: HaNaI, Obata and Hayami

Hn. 0023

Location: Tokuzo, southern coast of Hiraiga inlet

Str. position: upper part of the Hiraiga formation (lower Miyakoan)

Lithology: grey sandy shale

Fossils: Amphidonte (Amphidonte) subhaliotoidea (NAGAo)

Collector: HANAI

Hn. 0103

Location: northern coast of Hiraiga

Str. position: Hiraiga formation (lower Miyakoan)

Lithology: medium grey calcareous sandstone

Fossils: Chlamys robinaldina (D'ORBIGNY)

Collector: HANAI

Hn. 0220

Location: northern coast of Hiraiga inlet

Str. position: upper part of the Tanohata formation (lower Miyakoan)

Lithology: dark grey sandy shale

Fossils: Modiolus falcatus AmaNo, Atrina heiensis sp. nov. Neithea (Neithea) ficalhoi (Choffat), Limatula nagaoi sp. nov., Pterotrigonia hokkaidoana (Yehara), Pterotrigonia sp. cf. P. pocilliformis (Yokoyama), Anthonya subcantiana NAGAo, Pterotrigonia (Globocardium) sphaeroidea (FoRBES), Protocardia sp., Goniomya subarchiaci NAGAO 
Collectors: hanai, OBata and HaYami

Hn. 0299

Location: coast between Hiraiga and Raga (羅賀)

Str. position: upper part of the Hiraiga formation (Lower Miyakoan)

Lithology: fine grey calcareous sandstone

Fossils: Glycymeris (Hanaia) densilineata NAGAo, Neithea (Neithea) ficalhoi (Choffat), Neithea (Neithella) sp. cf. N. (N.) atava (RöMER), Pterotrigonia hokkaidoana (YEHARA)

Collectors: HaNaI, Obata and Hayami

Hn. 0310

Location: northern coast of Hiraiga inlet

Str. position: upper part of the Hiraiga formation (lower Miyakoan)

Lithology: grey sandy shale

Fossils: Amphidonte (Amphidonte) subhaliotoidea (NAGAo)

Collector: HaNaI

Hn. 0480*

Location: northern coast of Raga inlet

Str. position: "Orbitolina sandstone" (exactly indeterminable) (upper Miyakoan)

Lithology: fine grey calcareous sandstone

Fossils: Lopha (Arctostrea) carinata (LAMARCK)

Collector: HANAI

Hn. 0671

Location: coast of Hiraname (平波目), northeast of Raga

Str. position: upper part of the "Orbitolina sandstone" of the Miyako group (upper Miyakoan)

Lithology: fine grey calcareous sandstone

Fossils: Glycymeris (Hanaia) densilineata NAGAO, Neithea (Neithea) nipponica sp. nov., Pterotrigonia hokkaidoana (Yehara), Pterotrigonia sp. cf. P. datemasamunei (YEHARA), Eriphyla (Miyakoella) miyakoensis (NAGAO), Nagaoella corrugata (NAGAO)

Collector: HaYami

Hn. 0802

Location: coast of Koikorobe (コイコロべ), north of Shimanokoshi (島越)

Str. position: basal part of the Tanohata formation (lower Miyakoan)

Lithology: fine to medium grey sandstone

Fossils: Lopha (Lopha) nagaoi sp. nov., Amphidonte (Amphidonte) subhaliotoidea (Nagao), Nipponitrigonia kikuchiana (Yokoyama), Pterotrigonia hokkaidoana (Yehara), Eriphyla (Miyakoella) miyakoensis (NAGAO), Praecaprotina yaegashii (YEHARA)

Collectors: hanai, Obata and Hayami

Hn. 0803

Location: coast of Koikorobe, north of Shimanokoshi

Str. position: basal part of the Tanohata formation (lower Miyakoan)

Lithology: medium grey conglomeratic sandstone

Fossils: Isognomon (Mytiloperna) sp., Plicatula hanaii sp. nov., Liostrea sp. cf. L. cunabula (SEELEY), Lopha (Lopha) nagaoi sp. nov., Amphidonte (Ceratostreon) yabei (NAGAO), Nipponitrigonia kikuchiana (YoKoYAMA), Myoconcha modesta sp. nov., Eriphyla (Miyakoella) miyakoensis (NAGAO), Agapella (?) koikorobensis sp. nov., Praecaprotina yaegashii (YeHARA)

* This locality was erroneously recorded as "Hiraiga formation at the southern coast of Raga" in the Part I of this study (Mem. Fac. Sci., Kyushu Univ., Ser. D, Vol. 15, No. 2, p. 341, explanation of Plate 49). 
Collectors: Hanai, Obata and Hayami

Hn. 0905

Location: northern coast of Haipe (ハイペ) inlet, between Hiraiga and Shimanokoshi

Str. position: lower part of the Tanohata formation (lower Miyakoan)

Lithology: fine to medium grey sandstone

Fossils: Nipponitrigonia kikuchiana (YoкоYAMA), Praecaprotina yaegashii (YeHARA)

Collector: HaNaI and Hayami

Hn. $0911(\doteqdot \mathrm{Hn}$. 0912)

Location: northern coast of Haipe inlet, between Hiraiga and Shimanokoshi

Str. position: lower part of the Hiraiga formation (lower Miyakoan)

Lithology: fine grey calcareous sandstone

Fossils: Cucullaea acuticarinata NAGA0, Glycymeris (Hanaia) densilineata NAGA0, Eriphyla (Miyakoella) miyakoensis (NAGAO)

Collectors: hanai, Obata and Hayami

Hn. 0914

Location: northern coast of Haipe inlet, between Hiraiga and Shimanokoshi

Str. position: lower part of the Hiraiga formation (lower Miyakoan)

Lithology: fine grey calcareous sandstone

Fossils: Cucullaea acuticarinata NAGA0, Glycymeris (Hanaia) densilineata NAGA0, Pterotrigonia hokkaidoana (YEHARA), Astarte (Astarte) semicostata NAGA0, Astarte (Freiastarte) subomalioides NAGAO, Astarte (Nicaniella) minor NaGA0, Nagaoella corrugata (NAGAO), Nagaoella sp. cf. N. corrugata (NAGAO), Glycymeris (Glycymerita?) haipensis sp. nov.

Collector: HanaI, Obata and Hayami

Hn. 0916

Location: northern coast of Haipe inlet, between Hiraiga and Shimanokoshi

Str. position: lower part of the Hiraiga formation (lower Miyakoan)

Lithology: fine grey calcareous sandstone

Fossils: Cucullaea acuticarinata NAGAo, Glycymeris (Hanaia) densilineata NaGAo, Pterotrigonia hokkaidoana (YeHARA), Astarte (Astarte) semicostata NAGA0, Astarte (Astarte) semicostata NAGA0, Astarte (Freiastarte) subomalioides NAGA0, Astarte (Nicaniella?) minor NAGAO, Nagaoella corrugata (NAGAo), Nagaoella sp. cf. N. corrugata (NAGAO)

Collectors: HaNaI, OBata and Hayami

Hn. 0920

Location: northern coast of Haipe inlet, between Hiraiga and Shimanokoshi

Str. position: lower part of the Hiraiga formation (lower Miyakoan)

Lithology: fine grey calcareous sandstone

Fossils: Gervillaria miyakoensis (NAGAO)

Collector: HANAI and HAYAMI

Hn. $1903(\fallingdotseq$ Hn. 1904)

Location: southern coast of Haipe inlet, between Hiraiga and Shimanokoshi

Str. position: lower part of the Hiraiga formation (lower Miyakoan)

Lithology: fine grey calcareous sandstone

Fossils: Glycymeris (Hanaia) densilineata NAGAo, Nagaoella corrugata (NAGAo), Pterotrigonia hokkaidoana (YeHARA), Anthonya subcantiana NAGA0, Goniomya subarchiaci NAGAO, etc.

Collectors: Hanai, Obata and Hayami

Hn. 6201

Location: coast (road-cut) of Hiraname, northeast of Raga

Str. position: lower part of the Aketo formation (upper Miyakoan) 
Lithology: grey sandy shale

Fossils: Glycymeris (Hanaia) densilineata NAGAO, Neithea (Neithea) nipponica sp. nov., Neithea (s. l.) aketoensis sp. nov., Chlamys sp. cf. C. subacuta (LAMARCK), Ctenoides subrapa (NAGAO), Eriphyla (Eriphyla) pulchella sp. nov., Nagaoella corrugata (NAGAO), Goniomya subarchiaci NAGAO

Collectors: HaNaI, OBata and Hayami

Hn. $6203(\fallingdotseq \mathrm{Hn} .6202)$

Location: southern coast of Hiraname (road-cut), northeast of Raga

Str. position: uppermost part of the "Orbitolina sandstone" of the Miyako group (upper Miyakoan)

Lithology: grey sandy shale

Fossils: Nanonavis (Nanonavis) yokoyamai (YABE and NAGAO), Glycymeris (Hanaia) densilineata NAGAO, Gervillaria miyakoensis (NAGAO), Gervillia (Gervillia) forbesiana D'ORBIGNY, Atrina heiensis sp. nov., Neithea (Neithea) ficalhoi (Сhoffat), Lopha (Arctostrea) carinata (LAMARCK), Pterotrigonia pocilliformis (YокоYама), Pterotrigonia hokkaidoana (YehaRa), Pterotrigonia sp. $\mathrm{cf}$. $P$. datemasamunei (Yehara), Eriphyla (Eriphyla) pulchella sp. nov., Anthonya subcantiana NAGAO, Lucinoma (?) kotoi (NAGA0), Nagaoella corrugata (NAGAO), Panopea (Myopsis) plicata (SoWerBY), Pholadomya subpedelnalis NAGAO,

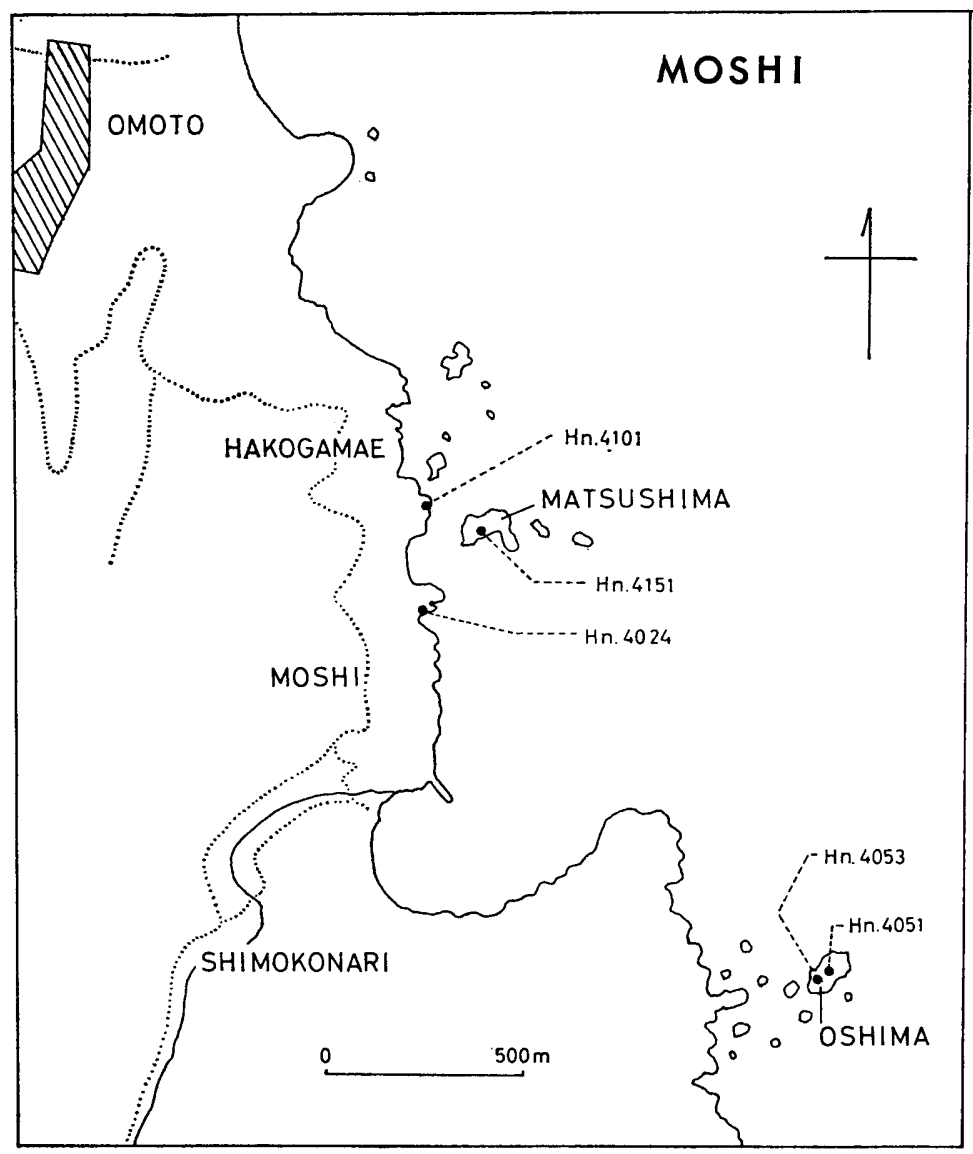

Fig. 2. Map showing the fossil localities in the Moshi area. 
Goniomya subarchiaci NAGA0, Cercomya gurgitis (PICTET and CAMPICHE), Offadesma altissimum sp. nov.

Collectors: HaNAI, OBATA and Hayami

2. Moshi area, Iwaizumi town, Shimohei County, Iwate Prefecture (岩手県下閉伊郡岩 泉町茂師) $141^{\circ} 58^{\prime} \mathrm{E}, 39^{\circ} 50^{\prime} \mathrm{N}$ (Fig. 2)

Hn. $4024(\fallingdotseq \mathrm{Hn} .4026)$

Location: coast of Mannenmon, northeast of Moshi

Str. position: upper part of the 1st cycle sediments of the Miyako group (lower Miyakoan)

Lithology: medium grey calcareous sandstone

Fossils: Nipponitrigonia kikuchiana (YoKoYAMA), Praecaprotina yaegashii (YeHARA)

Collectors: HaNaI and HaYami

Hn. 4051

Location: Oshima islet (大島), off the southeastern coast of Moshi

Str. position: 2nd cycle sediments of the Miyako group (lower Miyakoan)

Lithology: medium to fine grey sandstone

Fossils: Glycymeris (Glycymerita?) haipensis sp. nov., Liostrea sp. ex. gr. L. cunabula (SEeley), Nipponitrigonia kikuchiana (YoKoyama), Astarte (Freiastarte) subomalioides NAGAO, Eriphyla (Miyakoella) miyakoensis (NAGAO), Nagaoella corrugata (NAGAO)

Collectors: HaNAI, OBATA and HaYami

Hn. 4053

Location: Oshima islet, off the southeastern coast of Moshi

Str. position: 2nd cycle sediments of the Miyako group (lower Miyakoan)

Lithology: medium grey calcareous sandstone

Fossils: Mesosaccella insignis (NAGAO), Glycymeris (Hanaia) densilineata NAGAO, Lecompteus sp. cf. L. guerangeri (D'ORBIGNY), Mytilus sp., Antiquilima ultima sp. nov., Nipponitrigonia kikuchiana (YoKoYaMa)

Collectors: HANAI, OBATA and HaYami

Hn. 4101

Location: coast of Hakogamae, northeast of Moshi

Str. position: 1st cycle sediments of the Miyako group (lower Miyakoan)

Lithology: medium to fine grey sandstone

Fossils: Nipponitrigonia kikuchiana (Yoxoyama), Astarte (Freiastarte) subomalioides NAGAO, Praecaprotina yaegashii (YeHARA)

Collectors: HANAI and HAYAMI

Hn. 4151

Location: Matsushima islet (松島) of Hakogamae, northeast of Moshi

Str. position: 2nd cycle sediments of the Miyako group (lower Miyakoan)

Lithology: fine grey noduliferous sandstone

Fossils: Mesosaccella insignis (NAGAO), Astarte (Astarte) semicostata NAGAO, Astarte (Freiastarte) subomalioides NAGAO, Nagaoella corrugata (NAGAO)

Collectors: Hanar, Obata and Hayami

Hn. 4154

Location: Matsushima islet of Hakogamae, northeast of Moshi

Str. position: 2nd cycle sediments of the Miyako group (lower Miyakoan)

Lithology: fine grey calcareous sandstone

Fossils: Teredo matsushimaensis HataI

Collector: HANAI

3. Sakiyama area, Miyako City, Iwate Prefecture (岩手県宮古市䗁山地方) $141^{\circ} 58^{\prime} \mathrm{E}$, 


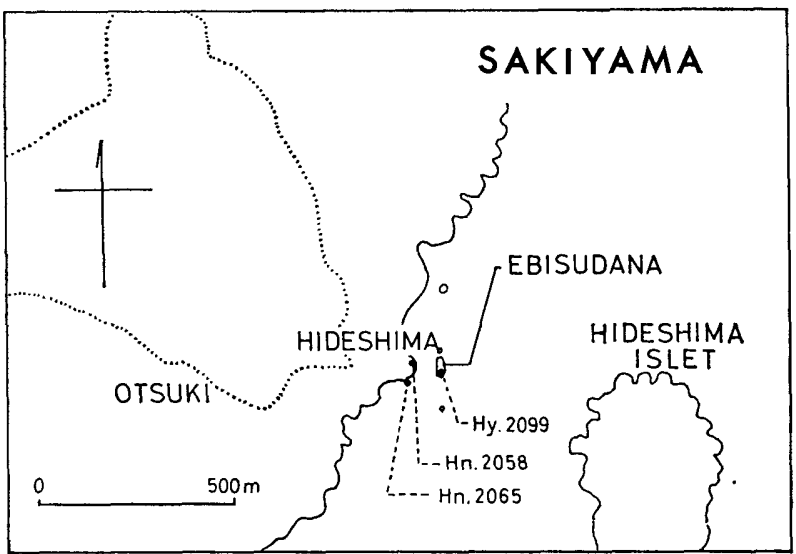

Fig. 3. Map showing the fossil localities in the Sakiyama area.

$39^{\circ} 40^{\prime} \mathrm{N}$ (Fig. 3)

Hn. 2058

Location: coast of Hideshima (日出島), Sakiyama

Str. position: upper part of the 1st cycle sediments of the Miyako group (lower Miyakoan)

Lithology: dark grey mudstone

Fossils: Amphidonte (Amphidonte) subhaliotoidea (NAGAo), Glycymeris (Hanaia) densilineata Nagao, Pseudocardia sp. cf. P. tenuicosta (Sowerby), Opis (Opis) nakanoi

Collectors: HANAI, NAKANo and HAYAMI

\section{Hn. 2065}

Location: coast of Hideshima, Sakiyama

Str. position: upper part of the 1st cycle sediments of the Miyako group (lower Miyakoan)

Lithology: dark grey mudstone

Fossils: Spondylus decoratus NaGaO

Collectors: HANAI and HAYAMI

Hy. 2099 ( $\fallingdotseq$ Hn. 2051)

Location: Ebisudana (戎棚), off the coast of Hideshima, Sakiyama

Str. position: lower part of the 2nd cycle sediments of the Miyako group (lower Miyakoan)

Lithology: fine grey calcareous sandstone

Fossils: Glycymeris (Hanaia) densilineata NAGAO, Neithea (Neithea) ficalhoi (CHoffat), Pterotrigonia hokkaidoana (YeHARA)

Collector: HAYAMI

4. Ofunato area, Ofunato City, Iwate Prefecture (岩手県大船渡地方) $141^{\circ} 41^{\prime} \mathrm{E}, 39^{\circ} 02^{\prime} \mathrm{N}$ Hy. 0054

Location: road-cut near Umagoé (馬越), west of the central part of Ofunato City

Str. position: Funagawara formation (? Aritan)

Lithology: black carbonaceous shale

Fossils: Liostrea sp., Eomiodon sakawanus (KовAYAshi and SUzuki), Neomiodon sp. cf. N. otsukai (YABE and NAGAO), Tetoria (Paracorbicula) sanchuensis (YABE and NAGAO)

Collector: HAYAMI 
5. Massaki area, Ofunato City, Iwate Prefecture (岩手県大船渡市末崎地方) $141^{\circ} 45^{\prime} \mathrm{E}$, $38^{\circ} 59^{\prime} \mathrm{N}$

Hy. 0051

Location: western coast of Goishi (碁石), Massaki

Str. position: Funagawara formation (? Aritan)

Lithology: fine grey sandstone

Fossils: Costocyrena radiatostriata (YABE and NAGAO), Tetoria (Paracorbicula) sanchuensis (YABE and NAGAO)

Collectors: OBata, TokUyama and Hayami

Hy. 0053

Location: coast facing Kinchakuiwa (巾着岩), north of Goishi, Massaki

Str. position: Hijiochi formation (? Aritan)

Lithology: black sandy shale and fine grey sandstone

Fossils: Pterotrigonia pocilliformis (Yokoyama), Veniella sp., Ptychomya densicostata NAGA0

Collectors: Obata, Tokuyama and Hayami

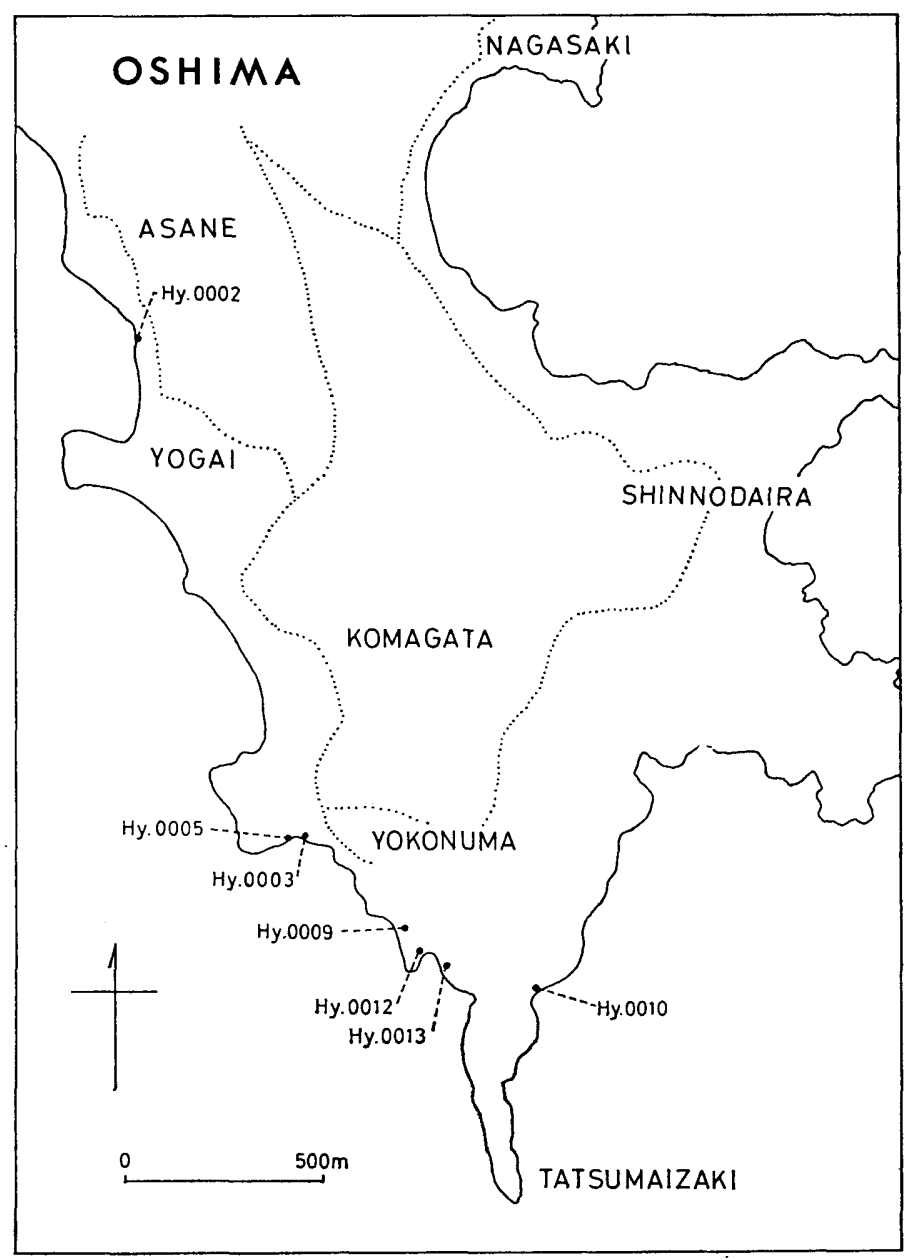

Fig. 4. Map showing the fossil localities in the Oshima area. 
6. Oshima area, Kesennuma City, Miyagi Prefecture (宮城県気仙沼市大島地方) $141^{\circ} 37^{\prime} \mathrm{E}$, $38^{\circ} 50^{\prime} \mathrm{N}$ (Fig. 4)

Hy. 0002

Location: southern coast of Asane (浅根), Oshima island

Str. position: middle part of the Oshima formation (Aritan)

Lithology: fine grey calcareous sandstone

Fossils: Gervillaria haradae (YokoYama), Pterotrigonia pocilliformis (YokoYama)

Collectors: Sugita, Nagumo and HaYami

Hy. 0003

Location: northern coast of Yokonuma ( 横沼), Oshima island

Str. position: upper part of the Oshima formation (Aritan)

Lithology: dark grey shale

Fossils: Lopha (Arctostrea) carinata (LAMARCK), Pterotrigonia pocilliformis (YOKOYAMA)

Collectors: OBATA and HaYami

Hy. 0009

Location: coast of Yokonuma, Oshima island

Str. position: upper part of the Oshima formation (Aritan)

Lithology: black shale

Fossils: Gryphaea (s. l.) oshimensis sp. nov., Astarte sp.

Collectors: OBATA and HAYAMI

Hy. 0010

Location: coast of Shiraito-hama (白系兵), southeast of Yokonuma, Oshima island

Str. position: upper part of the Oshima formation (Aritan)

Lithology: black sandy shale

Fossils: Nanonavis (Nanonavis) yokoyamai (YABE and NAGA0), ?Gervillaria haradae (YOKOYAMA), Gervillia (Gervillia) forbesiana D'ORBIGNY, Lopha (Arctostrea) carinata (LAMARCK), Pterotrigonia pocilliformis (YokoYama), Astarte (Astarte) sp.

Collectors: Sugita, Nagumo and Hayami

Hy. 0012

Location: southern coast of Yokonuma, Oshima island

Str. position: upper part of the Oshima formation (Aritan)

Lithology: black sandy shale

Fossils: Astarte (Astarte) sp. cf. A. (A.) subsenecta (YABE and NAGAo), Astarte (Astarte) sp.

Collectors: OBATA and HAYAMI

7. Choshi area, Chiba Prefecture (千葉県銚子地方) $140^{\circ} 52^{\prime} \mathrm{E}, 35^{\circ} 43^{\prime} \mathrm{N}$

Hy. 2001

Location: coast of Ashikajima (海鹿島), east of the central part of Choshi City

Str. position: Choshi formation (lower Miyakoan)

Lithology: fine grey sandstone

Fossils: Astarte (Astarte) costata YABE and NagAo

Collector: HAYAMI

Hy. 2003

Location: quarry near Ashikajima, east of the central part of Choshi City

Str. position: Choshi formation (lower Miyakoan)

Lithology: fine grey sandstone

Fossils: Cucullaea sp. cf. C. acuticarinata NAGAo, Isognomon (Isognomon) choshiensis sp. nov., Pterotrigonia sp. cf. P. pocilliformis (YokoYama), Panopea sp.

Collectors: HANAI and HAYAMI

8. Nakazato area, Tano County, Gumma Prefecture (群馬県多野郡中里村) $1^{3} 38^{\circ} 55^{\prime} \mathbf{E}$, 


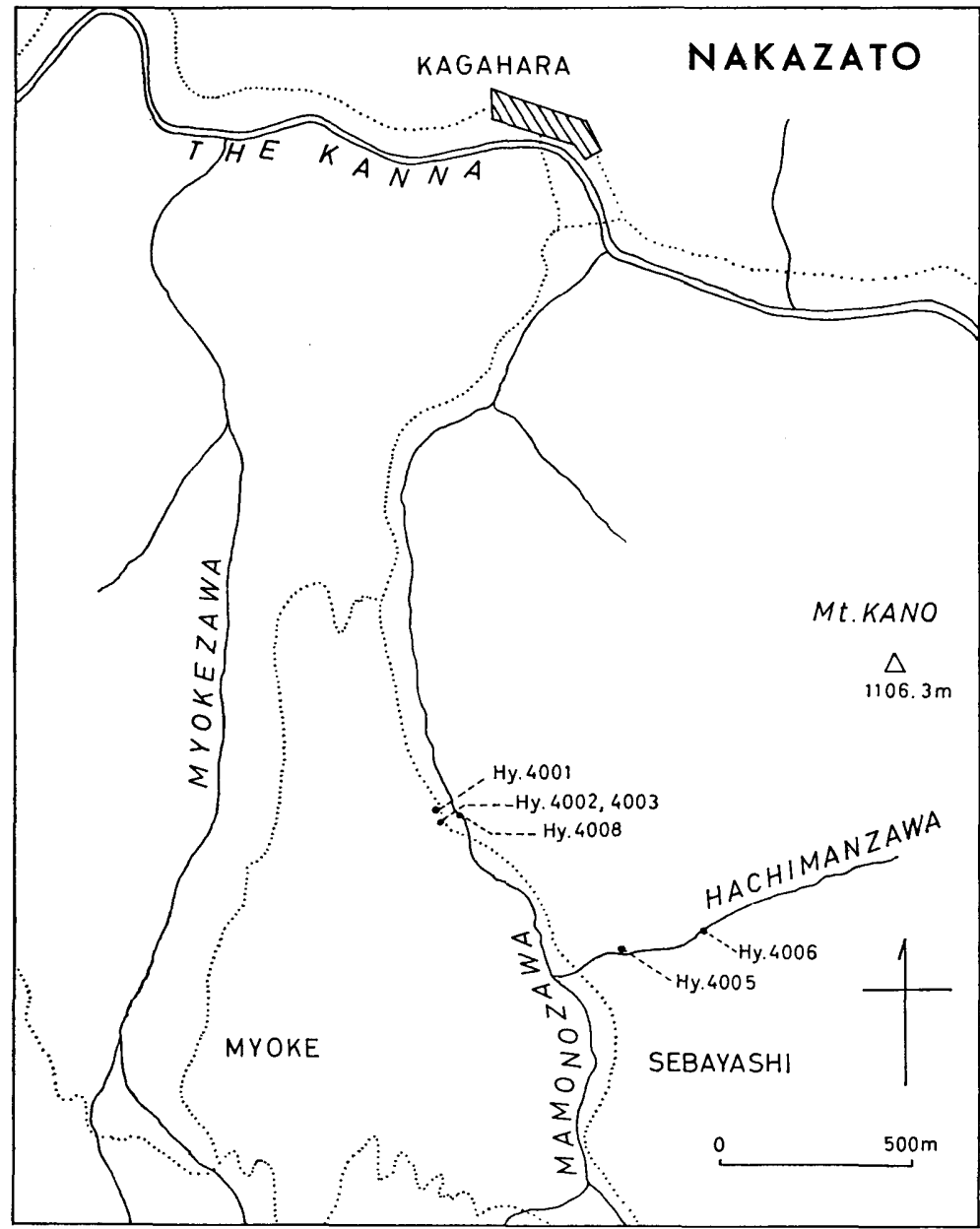

Fig. 5. Map showing the fossil localities in the Nakazato area.

\section{Hy. 4001}

\section{$36^{\circ} 00^{\prime} \mathrm{N}$ (Fig. 5)}

Location: Ichinose-bashi (一ノ瀬橋) of Sebayashi, south of Kagahara (神ケ原)

Str. position: middle part of the Ishido formation (Aritan)

Lithology: fine grey sandstone

Fossils: Nuculana (s. l.) sanchuensis YABE and NAGAO, Nanonavis (Nanonavis) yokoyamai (YABE and NAGAo), Gervillaria haradae (Yokoyama), Gervillia (Gervillia) forbesiana D'ORBIGNY, Neithea (Neithea) kanmerai sp. nov., Neithea (Neithea) sp., Entolium sanchuense sp. nov., Lopha (Arctostrea) carinata (LAmarck), Pterotrigonia pocilliformis (Yokoyama), Astarte (Astarte) subsenecta YABE and Nagao, Pachythaerus kagaharensis (Yokoyama), Anthonya sp., Ptychomya densicostata NAGAo, Pholadomya brevitesta NAGAo, Goniomya sp., Thracia sp.

Collectors: ICHIKAWA, SUgITA and HAYAMI

Hy. $4002(\doteqdot \mathrm{Hy} .4003)$

Location: Ichinose-bashi of Sebayashi (瀬林), south of Kagahara 
Str. position: middle part of the Ishido formation

Lithology: dark grey sandy shale

Fossils: Nuculana (s. l.) sanchuensis YABE and NAGAo, Nanonavis (Nanonavis) yokoyamai (YABE and NAGAO) Pterotrigonia pocilliformis (YokoYama), Astarte (Astarte) subsenecta YABE and NAGAo, Astarte (Astarte) costata Y $\mathrm{ABE}$ and NAGAo, Astarte (Yabea) shinanoensis YABE and NAGAo, Eriphyla (Eriphyla) minima sp. nov., Panopea (Myopsis) plicata (SOWERBY)

Collectors: Ichikawa, Sugita and HaYami

Hy. 4005

Location: lower valley of Hachimanzawa (八幡沢), near Sebayashi, south of Kagahara

Str. position: lower part of the Sebayashi formation (Miyakoan)

Lithology: black carbonaceous mudstone

Fossils: Isognomon (Isognomon) sanchuensis (YABE and NAGAO), Costocyrena radiatostriata (YABE and NAGAO)

\section{Collector: HAYAMI}

Hy. 4006

Location: middle valley of Hachimanzawa, northeast of Sebayashi (exactly unknown)

Str. position: Sebayashi formation (Miyakoan)

Lithology: black carbonaceous shale

Fossils: Liostrea sp., Nippononaia ryosekiana (SUzUkI), Protocyprina sp.

Collectors: ICHIKAWA and HAYAMI

\section{Hy. 4008}

Location: river floor near Ichinose-bashi, south of Kagahara

Str. position: middle part of the Ishido formation (Aritan)

Lithology: fine bluish grey sandstone

Fossils: Gervillaria haradae (Yokoyama), Pterotrigonia pocilliformis (Yokoyama)

Collectors: ICHIKAWA and HAYAMI

9. Ohinata area, Minamisaku County, Nagano Prefecture (長野県南佐久郡大日尚地方) $138^{\circ} 42^{\prime} \mathrm{E}, 36^{\circ} 08^{\prime} \mathrm{N}$ (Fig. 6)

Hy. 4011

Location: road-cut near Ishido (石堂), east of Koya (古谷)

Str. position: lower part of the Ishido formation (Aritan)

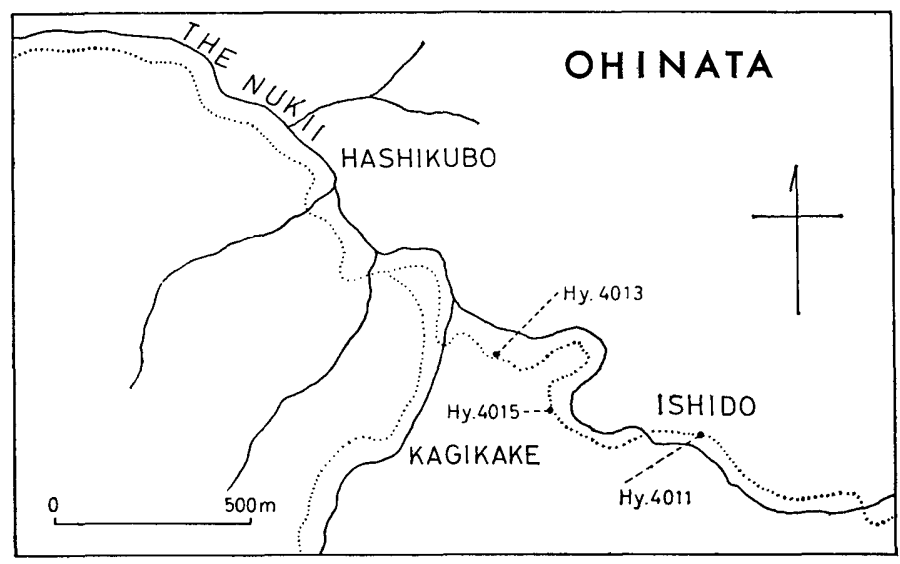

Fig. 6. Map showing the fossil localities in the Ohinata area. 
Fossils: Nanonavis (Nanonavis) yokoyamai (YABE and NaGAo), Amygdalum ishidoense (YABE and NAGAO), Gervillaria haradae (YoKoYAMA), Gervillia (Gervillia) forbesiana D'ORBIGNY, Isognomon (Melina) ichikawai sp. nov., Pinna sp. cf. $P$. robinaldina D'ORBIGNY, Neithea (Neithella) sp. cf. N. (N.) atava (RöMER), Limatula ishidoensis (YABE and NAGAO), Lopha (Arctostrea) carinata (LAMARCK), Nipponitrigonia plicata KoBAYASHI and NAKANo, Rutitrigonia sanchuensis (Nakano), Pterotrigonia pocilliformis (Yokoyama), Pterotrigonia yokoyamai (Yehara), Astarte (Astarte) subsenecta YABE and NaGA0, Isocyprina sp.

Collectors: ICHIKAWA and HAYAMI

Hy. 4013

Location: road-cut, west of Ishido

Str. position: middle part of the Ishido formation (Aritan)

Lithology: black shale

Fossils: Nanonavis (Nanonavis) yokoyamai (YABE and NAGAo), Pinna sp., Pterotrigonia sp.

Collector: HAYAMI

10. Yuasa area, Arita County, Wakayama Prefecture (和歌山県有田郡湯线地方) $135^{\circ} 10^{\prime} \mathrm{E} \pm, 34^{\circ} 03^{\prime} \mathrm{N} \pm$ (Fig. 7)

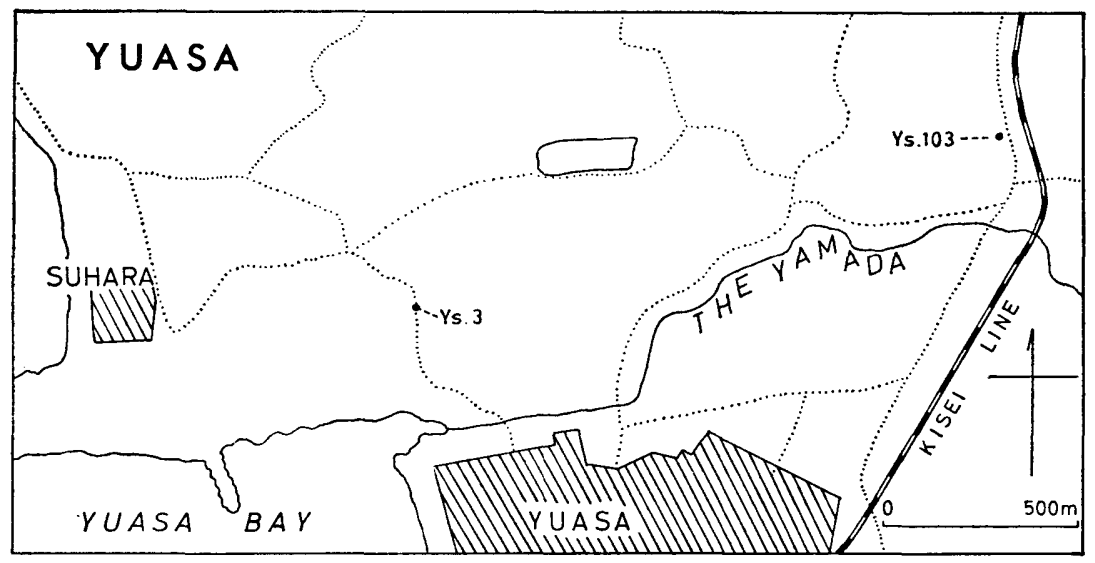

Fig. 7. Map showing the fossil localities in the Yuasa area.

Ys. 3

Location: near Suhara (栖原), north of the central part of Yuasa town

Str. position: lower part of the Arita formation (Aritan)

Lithology: black shale

Fossils: Nuculana (s. l.) sanchuensis YABE and NAGAO

Collector: Matsumoto

Ys. $8(=$ Hy. 3003)

Location: north of a pass between Yuasa and Yoshikawa (吉川)

Str. position: lower part of the Arita formation (Aritan)

Lithology: dark grey sandy shale

Fossils: Nanonavis (Nanonavis) yokoyamai (YABE and NAGAO), Plectomya aritagawana sp. nov.

Collector: Matsumoto

Ys. 103 (=Hy. 3006)

Location: a rail-road cut, west of Kumai (熊井) 
Str. position: middle part of the Arita formation (Aritan)

Lithology: fine grey sandstone and dark grey sandy shale

Fossils: Nuculopsis (Palaeonucula) ishidoensis (YABE and NAGAO), Nanonavis (Nanonavis) yokoyamai (YABE and NAGAo), Modiolus falcatus AMANo, Modiolus sp. aff. M. subsimplex D'ORBIGNy, Neithea (Neithea) kanmerai sp. nov., Plicatula kiiensis sp. nov., Pterotrigonia pocilliformis (YokoYama) Astarte (Astarte) subsenecta YABE and NAGAo, Ptychomya densicostata NAGAo, Panopea (Myopsis) nagaoi sp. nov., Plectomya aritagawana sp. nov.

Collectors: Matsumoto et al. and Hayami

Ys. 329a

Location: north of Oura (大浦), Minamihiro village (南広村)

Str. position: Arita formation (Aritan)

Lithology: grey sandy shale

Fossils: Pterinella shinoharai sp. nov., Gervillia (Gervillia) forbesiana D'ORBIGNY Collector: Matsumoto

Ys. 1020

Location: Yoshihara (吉原) of Ishigaki (石垣), Kanaya town (金谷町)

Str. position: lower part of the Izeki formation (Miyakoan)

Lithology: fine weathered sandstone

Fossils: Bakevellia shinanoensis (YABE and NAGAO), Liostrea sp., Costocyrena sp. aff. C. radiatostriata (YABE and NAGAO), Tetoria (Paracorbicula) sp.

Collector: Matsumoto

11. Katsuura area, Katsuura County, Tokushima Prefecture (徳島県勝浦郡勝浦地方)

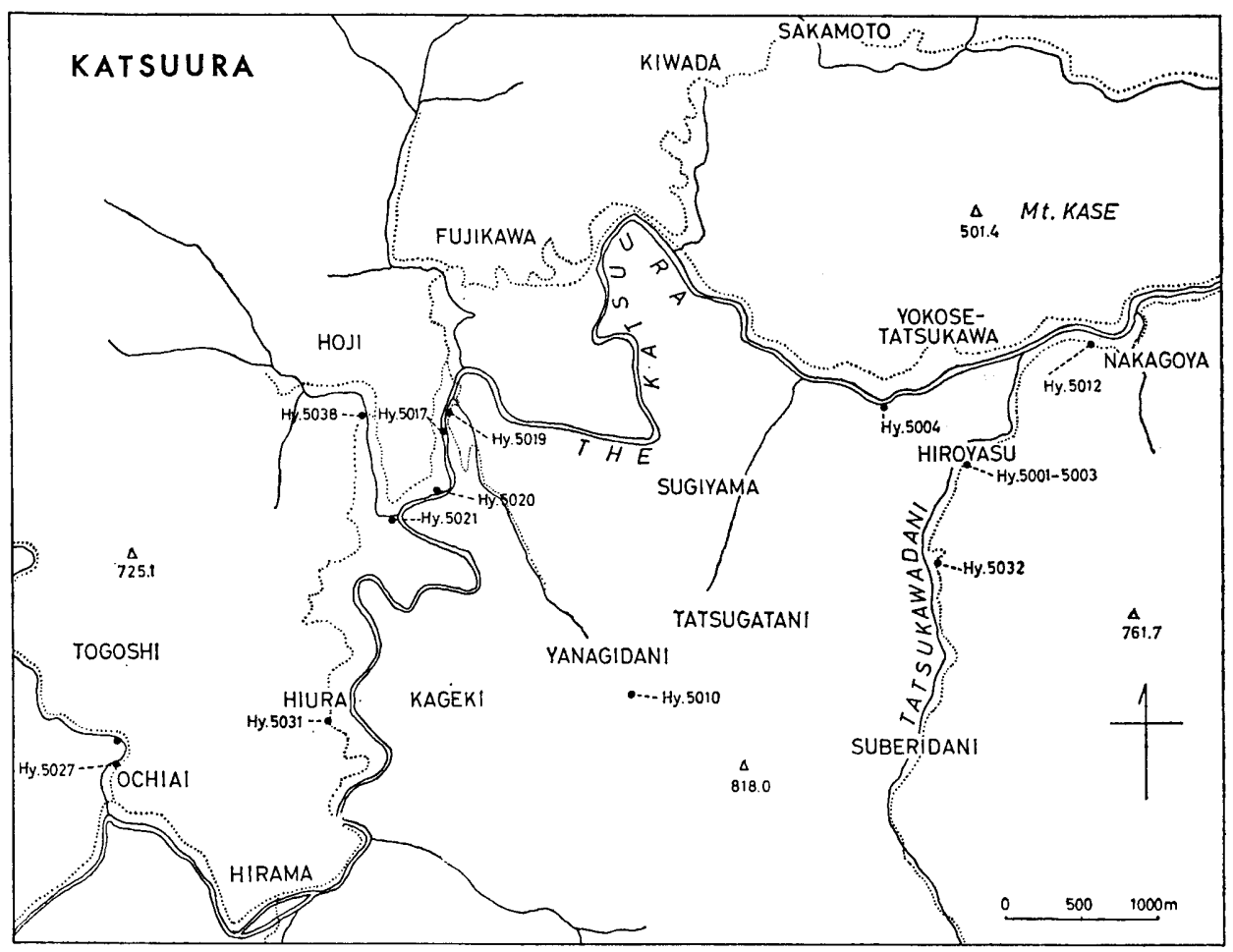

Fig. 8. Map showing the fossil localities in the Katsuura area. 
$134^{\circ} 26^{\prime} \mathrm{E} \pm, 33^{\circ} 54^{\prime} \mathrm{N} \pm$ (Fig. 8)

Hy 5002 ( $\doteqdot$ Hy. 5001, Hy. 5003)

Location: road-cut at the opposite side of Hiroyasu (広安), Katsuura town（勝浦町）

Str. position: upper part of the Hanoura formation (Aritan)

Lithology: fine grey sandstone and dark grey sandy shale

Fossils: Nuculopsis (Palaeonucula) ishidoensis (YABE and NAGAo), Nanonavis (Nanonavis) yokoyamai (YABE and NAGAO) Pterinella shinoharai sp. nov., Gervillia (Gervillia) forbesiana D'ORBIGNY, Neithea (Neithella) sp. cf. $N$. (N.) atava (RömER), Lopha (Arctostrea) carinata (LAMARCK), Pterotrigonia sp. cf. $P$. yokoyamai (YeHARA), Pterotrigonia pocilliformis (YoKoYAMA), Scittila japonica sp. nov., Scittila sp., Pholadomya sp., Plectomya aritagawana sp. nov.

Collectors: MATsumoto, NAKaI and HaYami

Hy. 5004

Location: southern bank of Katsuura river, northwest of Hiroyasu, Katsuura town

Str. position: upper part of the Hanoura formation (Aritan)

Lithology: grey calcareous sandy shale

Fossils: Pterinella shinoharai sp. nov., Neithea (Neithea) kanmerai sp. nov., Astarte (Astarte) subsenecta YABE and NAGAO, Panopea (Myopsis) sp. cf. $P .(M$. plicata (SowERBY)

Collectors: NAKAI and HAYAMI

Hy. $5010(\doteqdot \mathrm{Hy} .5011)$

Location: road-cut at the east of Nakagoya (中小屋), Katsuura town

Str. position: lower part of the Hanoura formation (Aritan)

Lithology: dark grey shale

Fossils: Nuculopsis (Palaeonucula) ishidoensis (YABE and NAGA0), Nuculana (s.l.) sanchuensis YABE and NAGAO

Collectors: NAKAI and HAYAMI

Hy. 5012 ( $\doteqdot \mathrm{Hy}$. 5015)

Location: road-cut at the west of Nakagoya, Katsuura town

Str. position: lower part of the Hanoura formation (Aritan)

Lithology: dark grey shale

Fossils: Astarte (Astarte) subsenecta YABE and NAGAO

Collectors: NAKAI and HAYAMI

Hy. 5017

Location: western bank of Katsuura river near Katsuura coal mine, south of Fujikawa (藤川), Kamikatsu town

Str. position: upper part of the Hoji formation (Miyakoan)

Lithology: fine grey sandstone

Fossils: Nuculopsis (Palaeonucula) ishidoensis (YABE and NAGAO), Gervillia (Gervillia) forbesiana D'ORBIGNy, Nipponitrigonia sp., Pterotrigonia pocilliformis (YOKOYAMA)

Collectors: Numano, NaKaI and HaYami

Hy. 5019

Location: road-cut at the opposite side of Katsuura coal mine, south of Fujikawa

Str. position: upper part of the Hoji formation (Miyakoan)

Lithology: fine grey sandstone

Fossils: Nipponitrigonia kikuchiana (YoKoyama), Nipponitrigonia plicata KoBAYASHI and NAKANO, Isocyprina aliquantula AMANo

Collectors: NAKAI and HAYAMI

Hy. $5021(\div$ Hy. 5022)

Location: western bank of the Katsuura river, near the mouth of the valley of Hoji (傍示), Kamikatsu town

Str. position: lower part of the Hoji formation (Miyakoan) 
Lithology: fine grey sandstone

Fossils: Pterotrigonia pocilliformis (Yokoyama), Lopha sp.

Collectors: NAKAI and HAYAMI

Hy. 5027 ( $\doteqdot$ Hy. 5028)

Location: river floor at the northwest of the primary school, Ochiai (落合), Kamikatsu town

Str. position: middle part of the Hoji formation (Miyakoan)

Lithology: fine grey carbonaceous sandstone and black shale

Fossils: Eomiodon sakawanus (KoBAyASHI and SUzUKI), Tetoria (Paracorbicula) sp., ? Lopha sp.

Collectors: MATSUmoto, NaKaI and Hayami

Hy. 5031

Location: road-cut at the north of Hiura (日浦), Kamikatsu town

Str. position: middle part of the Hoji formation (Miyakoan)

Lithology: black carbonaceous sandy shale

Fossils: Eomiodon sakawanus (KoBAYASHI and SUZukI), Tetoria (Paracorbicula) sp.

Collectors: NAKAI and HAYAMI

12. Monobegawa area, Kami County, Kochi Prefecture (高知県賀美郡物部川地方) $133^{\circ} 43^{\prime} \mathrm{E}, 33^{\circ} 37^{\prime} \mathrm{N}$ (Fig. 9)

Hy. 6011

Location: south of Hagino (萩野), Mirafu village (美良布村)

Str. position: upper part of the Monobegawa group or Hagino formation (lower Miyakoan)

Lithology: fine bluish grey (yellowish if weathered) sandstone

Fossils: Eonavicula prolata (AMANo), Nemodon (?) sp., Cucullaea fujii sp. nov., Trigonarca obliquata AmANo, Gervillaria sp. cf. G. haradae (YoKoYAMA), Modiolus falcatus AMANo, Chlamys shikokuensis Amano, Neithea (Neithea) amanoi sp. nov., Eriphyla (Miyakoella) sp. cf. E. (M.) miyakoensis (NAGAO), Opis (Opis) haginoensis AmaNo, Pachythaerus sp. cf. P. kagaharensis (YoKoYAMA), Protocardia sp., Laevicardium (?) corpulentum (AMANo), Isocyprina aliqu-

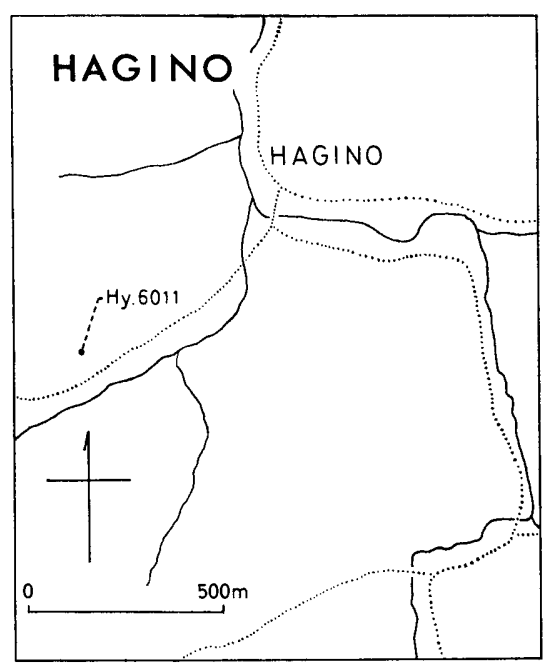

Fig. 9. Map showing the fossil localities in the Hagino area. 
antula (Amano), Scittila sp. cf. S. japonica Hayami, Panopea (Myopsis) sp. cf. $P$. (M.) plicata (Sowerby), Pholadomya sp. aff. $P$. cornueliana D'Orbigny, Plectomya sp. cf. $P$. aritagawana HAYAMI

Collectors: Amano, NAKano, OGaWa and HaYami

13. Ryoseki area, Nangoku City, Kochi Prefecture (高知県南国市領石地方) $133^{\circ} 37^{\prime} \mathrm{E}$, $33^{\circ} 37^{\prime} \mathrm{N}$ (Fig. 10)

Hy. 6002

Location: road-cut near the mouth of the valley of Okunominotani (奥䇾谷), southwest of Ryoseki (領石)

Str. position: lower part of the Monobegawa group or Funadani formation (Aritan)

Lithology: dark grey shale

Fossils: Chlamys (?) shikokuensis Amano, Variamussium kimurai sp. nov., Astarte sp.

Collectors: Kimura and Hayami

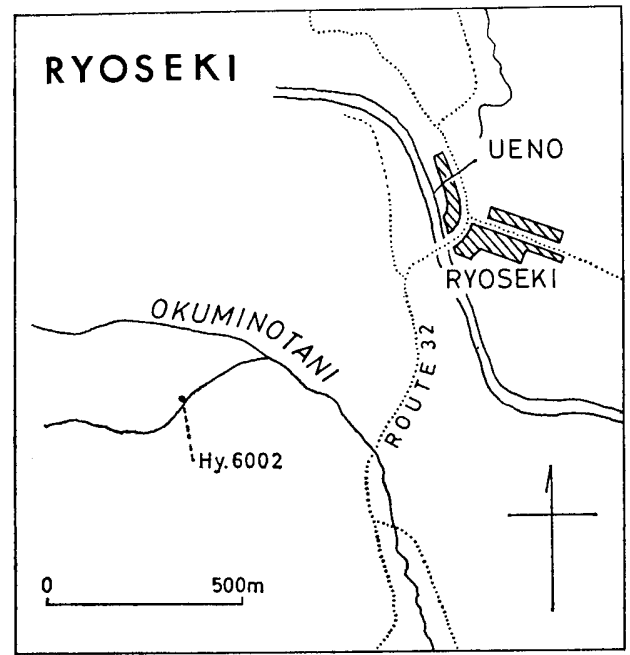

Fig. 10. Map showing the fossil localities in the Ryoseki area.

14. Haidateyama area, Ono County, Oita Prefecture (大分県大野郡楓楯山地方) $131^{\circ} 43^{\prime} \mathrm{E}$, $33^{\circ} 02$ ' N

U. 1005

Location: roadside between Tamarimizu (溜水) and Ochiai (落合), Nozu town ( 野津町)

Str. position: comparable strata with the Haidateyama formation (Miyakoan)

Lithology: fine weathered brownish sandstone

Fossils: Parallelodon nipponicus (NAGAO), Nanonavis (Nanonavis) yokoyamai (YABE and NAGA0), Cucullaea fujii sp. nov., Neithea (Neithea) matsumotoi sp. nov., Pterotrigonia pocilliformis (Yokoyama), Veniella (?) sp.

Collectors: KANMERA and FUJII

U. 3095

Location: Yamaguchi-no-tani (山口ノ谷), Mie town (三重町)

Str. position: Haidateyama formation (Miyakoan)

Lithology: dark grey sandy shale

Fossils: Astarte (Astarte) subsenecta YABE and NAGAO 
Collector: FUJII

Hy. 8002

Location: road-cut at the north of Kamikoshigoe (上腰越), Honjo village (本左村), Minamiamabe County (南海部郡)

Str. position: Haidateyama formation (Miyakoan)

Lithology: dark grey sandy shale and fine grey sandstone

Fossils: Neithea (Neithea) sp., Pterotrigonia pocilliformis (Yokoyama), Pterotrigonia sp. cf. P. datemasamunei (YEHARA)

Collector: HAYAMI

15. Yatsushiro area, Kumamoto Prefecture (熊本県八代地方) $130^{\circ} 40^{\prime} \mathrm{E} \pm 32^{\circ} 30^{\prime} \mathrm{N} \pm$ (Fig. 11)

At. 328

Location: south of Bisho (美生), Toyo village (東陽村), Yatsushiro County

Str. position: Yatsushiro formation (upper Miyakoan)

Lithology: fine grey sandstone

Fossils: Astarte (Astarte) subsenecta YABE and NAGAo, Astarte (Yabea) akatsui sp. nov., Eriphyla (Eriphyla) minima sp. nov.

Collector: AkATsU

At $828 \mathrm{~A}(\doteqdot \mathrm{Hy}$. 1021)

Location: road-side at the south of Bisho, Toyo village

Str. position: Yatsushiro formation (upper Miyakoan)

Lithology: fine grey sandstone

Fossils: Gervillaria haradae (YoKoyAma), Gervillia (Gervillia) forbesiana D'ORBIGNY, Pterotrigonia pocilliformis (YokoYama), Laevicardium (?) ishidoense (YABE and NAGAO)

Collectors: AKATSU and HAYAMI

Hy. 1007

Location: a small valley at the southwest of Kohara (小原), Toyo village

Str. position: Yatsushiro formation (upper Miyakoan)

Lithology: dark grey sandy shale

Fossils: Nanonavis (Nanonavis) sp. cf. N. (N.) yokoyamai (YABE and NAGAo), Pterotrigonia pocilliformis (YOKOYAMA)

Collector: HAYAMI

Hy. 1012

Location: road-cut at the north of Nekodani (猫谷), Yatsushiro City

Str. position: Yatsushiro formation (upper Miyakoan)

Lithology: Nanonavis (Nanonavis) yokoyamai (YABE and NAGAo), Pterinella shinoharai sp. nov., Lopha (Arctostrea) carinata (LAMARCK), Pterotrigonia pocilliformis (Yoкоуама), Nemocardium yatsushiroense sp. nov., Panopea sp., Astarte sp.

Collectors: Amano, Tamura and Hayami

Km. $1639 \mathrm{~b}$

Location: left bank of the Kuma river, Takada (高田), northwest of Harameki (原女木), Yatsushiro City

Str. position: lower part of the Hinagu formation (lower Miyakoan)

Lithology: fine grey sandstone

Fossils: Costocyrena sp. cf. C. matsumotoi HAYAMI, "Nakamuranaia" chingshanensis (GrABAU)

Collector: KANMERA

Km. 1832

Location: road-side at the northeast of Tsuzura (九折), Sakamoto town (坂本町)

Str. position: Hinagu formation (lower Miyakoan) 


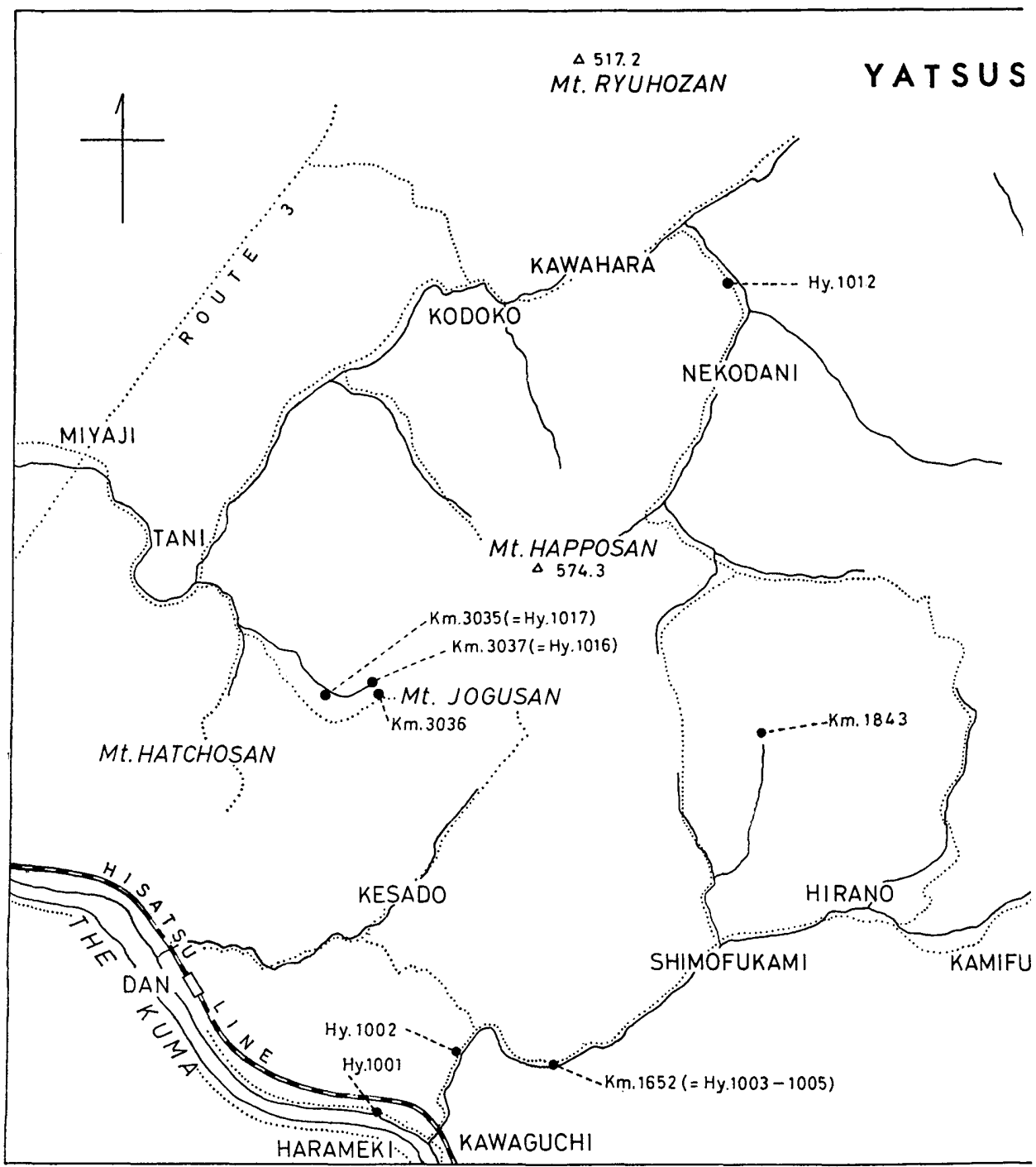

Fig. 11. Map showing the fossil

Lithology: dark grey sandy shale

Fossils: Nuculana (s. l.) sanchuensis YABE and NAGAo, Pinna sp. cf. P. robinaldina D'ORBIGNY

Collector: KANMERA

Km. $1843(\doteqdot$ Hy. 1001)

Location: north of Shimofukami (下深水), Sakamoto town

Str. position: Yatsushiro formation (upper Miyakoan)

Lithology: grey fine sandstone

Fossils: Parallelodon nipponicus (NAGAo), Pterinella shinoharai sp. nov., Bakevellia pseudorostrata (NAGAO), Neithea (Neithea) matsumotoi sp. nov., Entolium (?) yatsushiroense sp. nov., Limatula sp. cf. L. nagaoi HAYAMI, Lopha (Arctostrea) carinata (LAMARCK), Nipponitrigonia plicata KoBAYASH and NAKANo, 


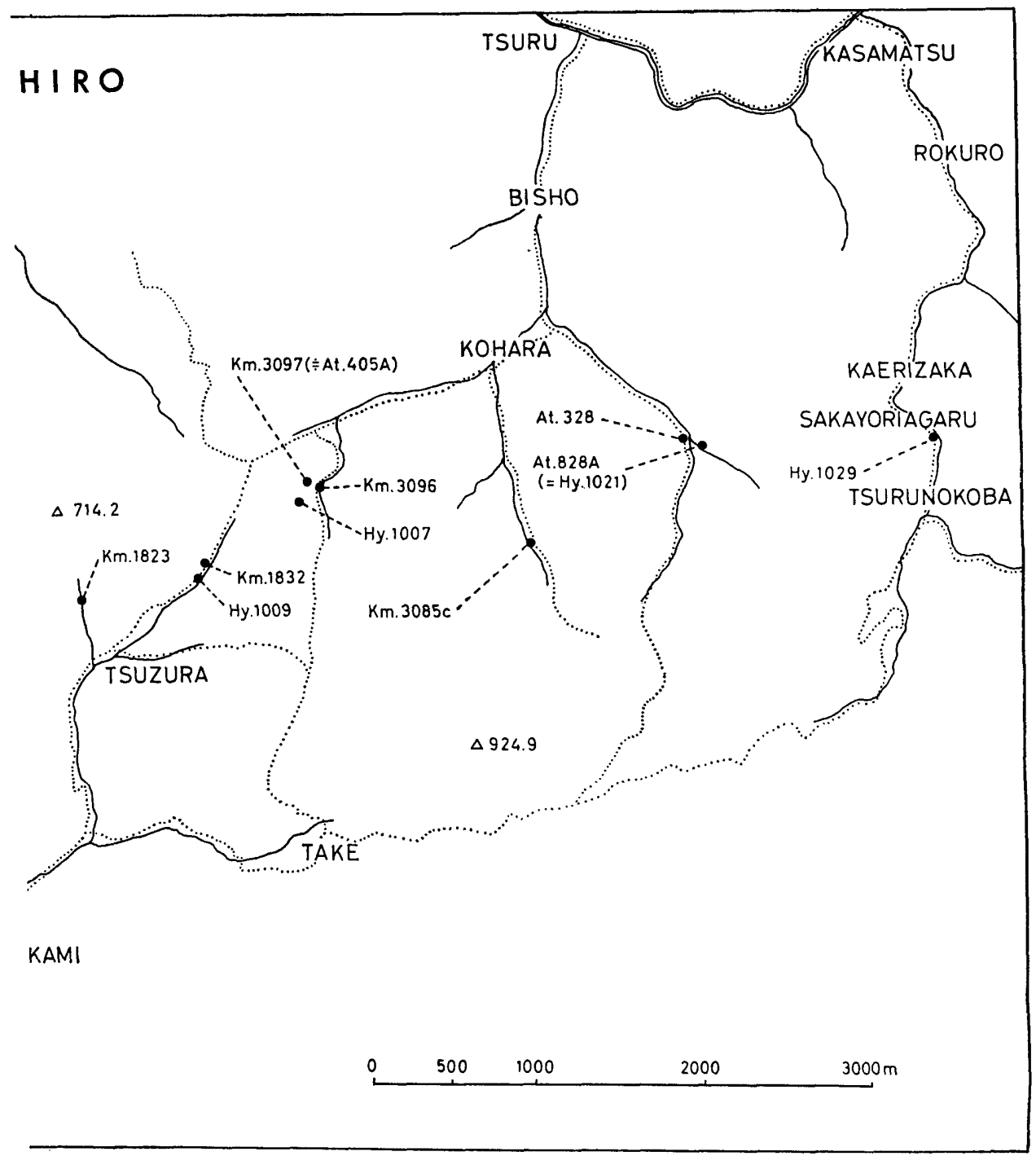

localities in the Yatsushiro area.

Rutitrigonia sanchuensis (Nakano), Pterotrigonia pocilliformis (Yokoyama), Acanthotrigonia sp. cf. A. dilapsa (YeHARA), Anthonya sp., Fimbria sp., Laevicardium (?) ishidoense (YABE and NAGAO), Ptychomya densicostata NAGAO, Panopea (Myopsis) nagaoi sp. nov., Goniomya sp., Pholadomya sp.

Collectors: KANMERA and HAYAMI

Km. 3035 ( $\doteqdot$ Hy. 1017)

Location: western slope of Mt. Jogusan (上宮山), Miyaji (宮地), Yatsushiro City Str. position: Yatsushiro formation (upper Miyakoan)

Lithology: fine grey sandstone and dark grey sandy shale

Fossils: Monia sp. cf. M. pseudotruncata (YABE and NAGAO), Costocyrena matsumotoi sp. nov., Tetoria (Paracorbicula) sp.

Collectors: KANMERA and HAYAMI 
Km. 3036

Location: western slope of Mt. Jogusan, Miyaji, Yatsushiro City

Str. position: Yatsushiro formation (upper Miyakoan)

Lithology: grey sandy shale

Fossils: Pterotrigonia pocilliformis (YokoYama)

Collector: KANMERA

Km. 3037 ( $\doteqdot$ Hy. 1016)

Location: western slope of Mt. Jogusan, Miyaji, Yatsushiro City

Str. position: grey sandy shale

Fossils: Nanonavis (Nanonavis) yokoyamai (YABE and NAGAo), Pterinella shinoharai sp. nov., Neithea (Neithea) matsumotoi sp. nov., Pterotrigonia pocilliformis (Yokoyama), Astarte (Astarte) subsenecta YABE and NAGAO, Astarte (Freiastarte) sp. cf. A. (F.) subomalioides NAGAO, Nemocardium yatsushiroense sp. nov., Plectomya sp. cf. $P$. aritagawana HaYAmi

Collectors: KANMERA, FUJII and HAYAMI

$\mathrm{Km} .3085 \mathrm{c}$

Location: south of Kohara, Toyo village

Str. position: Hinagu formation (lower Miyakoan)

Lithology: medium grey conglomeratic sandstone

Fossils: Neithea (Neithea) kanmerai sp. nov., Plicatula kiiensis sp. nov., Astarte (Astarte) subsenecta YABE and NAGAO

Collector: KANMERA

Km. 3096 ( $\doteqdot \mathrm{Km} .3097)$

Location: a small valley, southwest of Kohara, Toyo village

Str. position: Yatsushiro formation (upper Miyakoan)

Lithology: dark grey sandy shale

Fossils: Mesosaccela sp., Nuculana (s. l.) sanchuensis (YABE and NAGAO), Nanonavis (Nanonavis) yokoyamai (YABE and NAGA0), Gervillia (Gervillia) forbesiana D'ORBIGNY, Pterotrigonia pocilliformis (YoKoyama), Acanthotrigonia sp. cf. A. dilapsa (Yehara), Panopea (Myopsis) nagaoi sp. nov., Goniomya sp.

Collectors: KANMERA and HAYAMI

$\mathrm{Km} .3134$

Location: northwestern slope of the peak of $251 \mathrm{~m}$, Kongo (金剛), Yatsushiro City Str. position:: Hinagu formation (lower Miyakoan)

Lithology: fine grey sandstone

Fossils: Parallelodon nipponicus (NAGAo), Nipponitrigonia kikuchiana (YokoYAMA), Pterotrigonia hokkaidoana (YeHARA), Pterotrigonia (Rinetrigonia) sp.

Collector: KANMERA

\section{References}

Adkins, W. S. (1928) : Handbook of Texas Cretaceous fossils. Texas Univ., Bull., 2838, 1-303, pls. 1-37.

and Winton, W. M. (1919) : Paleontological correlation of the Fredericksburg and Washita formations in north Texas. Ibid., 1945, 1-84, pls. 1-21.

Agassiz, L. (1840-1845): Études critiques sur les Mollusques fossiles. 287 pp., 104 pls. Paris.

Alencaster de Cserna, Gloria (1956): Pelecipodos y gasteropodos del Cretacico inferior de la region de San Juan Rayazapotitlan, Estado de puebla. Paleont. Mexicana, 2, 1-47. pls. 1-7.

Allison, Edwin C. (1955) : Middle Cretaceous Gastropoda from Punta China, Baja California, Mexico. Jour. Paleont., 29, (3), 400-432, pls. 40-44. 
Amano, Masahisa (1956): Some Upper Cretaceous fossils from southwestern Japan (Part 1). Kumamoto Jour. Sci., [B], [I], 2, (1), 63-86, pls. 1, 2.

(1957) : Upper Cretaceous molluscan fossils from Shimo-koshiki-jima, Kyushu. Ibid., [B], [I], 2, (2), 51-75, pls. 1, 2.

(1957a): The Lower Cretaceous fauna from Hagino in southern Shikoku, Japan. Ibid., [B], [I], 2, (2), 77-121, pls. 1, 2.

(1962) : The geologic history of the Paleo-Shiiranuhi Bay in the Neo-Cretaceous period (Part 2. Regional Geology). Ibid., [B], [I], 5, (1), 1-36, 3 maps.

- and Marui, Nobuyuki (1958): On the new species of Spondylus from the Creatceous formation in Nagano Prefecture. Ibid., [B], [I], 3, (1), 27-30, pl. 2. , OGata Shinsuke and NiRE Naomichi (1958): On the Tendagurium from the lower bed of the Goshonoura group in Shishijima, Kagoshima Prefecture, Kyushu, Japan. Ibid., [B], [I], 3, (1), 17-20, pl. 1.

Anderson, F. M. (1938): Lower Cretaceous deposits in California and Oregon. Geol. Soc. America, Spec. Papers, 16, 1-339, pls. 1-84.

Anderson, F. W. and Cox, Leslie Reginald (1948): The "Loch Staffin beds" of Skye; with notes on the molluscan fauna of the Great Estuarine series. Proc. Royal Phys. Soc., 23, (2), 103-122, pls. 1-3.

ARKeLL, William Joscelyn (1929-1937): A monograph of British Corallian Lamellibranchia. xxxviii+392pp., 56pls. Palaeontogr. Soc. London.

(1930): The generic position and phylogeny of some Jurassic Arcidae. Geol. Mag., 67, 297-310, 337-352, pls. 14-16.

BARBER, W. (1958) : Upper Cretaceous Mollusca from northeastern Nigeria. Rec. Geol. Surv. Nigeria, 1956, 14-37, pls. 5-9.

BASse, E. (1933): Paléontologie de Madagascar XVIII-Faune malacologique du Crétacé superieur du sud-ouest de Madagascar. Ann. Paléont., 21, (3-4), 91168, pls. 1-9.

BAyLe, E. (1878) : Explication de la carte géologique de France. Vol. 4, Pt. 1. Fossiles principaux des terrains. pls. 103-148. Paris.

Behrendsen, O. (1891): Zur Geologie des Ostabhanges der argentinischen Cordillere. Zeit. deutsch. geol. Gesell., 43, 369-389.

Bigot, A. (1904) : Trigonia cardissoides LAmarck, 1819. Palaeont. Universalis, [1], 2, 21, 21a.

(1906): Gervillia solenoides DeFrance, 1820. Ibid., [2], 2, 95, 95a, b.

Blanckenhorn, Max (1934) : Die Bivalven der Kreideformation von Syrien-Palestina. 81, (A), 161-302, pls. 7-14.

Bodylevsky, W. and Shulgina, I. (1958): Jurassic and Cretaceous fauna of Lower Yenisei. Trans. All Soviet Union, Arct. Geol. Inst., 93, 1-196 (pls. 1-45 incl.) (in Russian)

Böнм, Johannes (1917): Ueber die Gattungen Eriphyla Gabb, Dozyia Bosquet und Freia Joh. Böhm. Zeit. deutsch. geol. Gesell., 69, 20-30.

(1920): Zur systematischen Stellung der Gattung Neithea Drouet. Jahrb. preuss. geol. Landes., 40, (2), 129-147.

Böse, E. (1910) : Monografia geologica y paleontologica del cerro de Mueros cerca de Ciudad Juarez, Estado de Chihuahua y description de la fauna cretacéa de la Encantada, Placer de Guadalupe, Estado de Chihuahua. Bol. Inst. Geol. Mexico, 25, 1-193, pls. 1-48.

BRINkMANN, Roland (1959): Abriss der Geologie. Zweiter Band. Historische Geologie. viii +360 p. Ferdinand Enke, Stuttgart.

BURCK HARDT, C. (1903) : Beiträge aur Kenntnis der Jura- und Kreideformation der Cordillere. Palaeontographica, 50, 1-144, pls. 1-16.

CASEY, Raymond (1952): Some genera and subgenera, mainly new, of Mesozoic heterodont lamellibranchs. Proc. Malacol. Soc. London, 29, 121-176. 
(1955): The Neomiodontidae, a new family of the Arcticacea (Pelecypoda). Ibid., 31, (5-6), 208-22i2, pl. 11.

(1955a): The pelecypod family Corbiculidae in the Mesozoic of Europe and the Near East. Jour. Washington Acad. Sci., 45, (12), 366-372).

(1961): The stratigraphical palaeontology of the Lower Greensand. Palaeontology, 3, (4), 487-621, pls. 77-84.

Chavan, André (1937-1938): Essai critique de classification des Lucines. I (1937), Jour. Conchyl., 81, 133-153; II (1937), Ibid., 81, 198-216; III (1937), Ibid., 81, 237-282; IV (1938), Ibid., 82, 59-97; V (1938), Ibid., 82, 105-130; VI (1938), Ibid., 82, 215-243.

(1939): Sur quelques Crassatellidae tertiaires: Chattonia, Crassatina, Crassinella. Bull. Musée roy. d'Hist. nat. Belgique, 15, (34), 1-36.

(1941): Sur la position systématique du genre Eriphyla Gabb. C. R. Soc. géol. France, (14), 108-109.

(1945) : Les lamellibranches hétérodontes des sables astartiens de Cordebugle (Calvados). I. Astartidae, Cyprinidae, Isocardiidae. Jour. Conchyl., 86, 41-86, pl. 1.

(1957): La faune campanienne du Mont des Oliviers d'aprèe les matériaux Vignal-Grassé. Ibid., 87, 125-197, pls. 1-4.

(1950): Deux intéressants lamellibranches des sables astartiens de Cordebugle (Calvados). Ibid., 90, 207-213.

(1952): Les pélécypodes des sables astartiens de Cordebugle (Calvados). Mém. Suiss. Paléont., 69, 1-132, pls. 1-4.

(1952a): L'interpretation du genre Ptychomya Agassiz. C. R. Soc. géol. France, (9), 161-163.

(1952b) : Distinction et classement des Astartidés. Cahiers géol. Thoiry, 15, $123-127$.

Chelot, E. (1908) : Lima rapa D'ORBIGNy, 1847. Palaeont. Universalis, [2], 3, 128, $128 \mathrm{a}$.

(1910): Lima simplex D'ORBIGNY, 1847. Ibid., [3], 1, 182, 182a.

Choffat, Paul (1901-1902): Recueil d'études paléontologiques sur la faune crêtacique du Portugal. Vol. 1. Espèces nouvelles ou peu connues. Ser. 3-4, 89-171, pls. 1-7. Comm. Serv. géol. Portugal.

and DE LORIOL, P. (1888): Matériaux pour l'Etude stratigraphique et paléontologique de la province d'Angola. Mém. Soc. Phys. d'Hist. nat. Genève, 30, (2), 1-116, pls. 1-8.

Clark, William Bellock and Martin G. C. (1901): Systematic paleontology. Eocene Mollusca. in Clark, W. B. et al.: Eocene. 122-203, pls. 17-57. Maryland Geol. Surv.

Collignon, Maurice (1939): Fossiles cénomaniens et turoniens du Menabe de Madagascar. Ann. géol. Surv. Mines, Madagascar, 10, 1-49, pls.1-11.

ConRAD, Timothy Abbott (1875): Descriptions of new genera and species of fossil shells of North Carolina. Appendix in Report of the Geological Survey of North Carolina, 1, 28pp., pls. 1-4.

Coquand, H. (1869) : Monographie du genre Ostrea. Terrain crétacé. 215 pp., 75 pls. Marseille.

Cossmann, M. (1907): Description des gastropodes et pélécypodes, in Pellat, E. and Cossmann, M.: Le Barremien supérieur à faciès Urgonien de Brouzet-les-Alais (Gard). Soc. géol. France, Mém. Paléont., 37, 6-42, pls. 1-6.

(1911): Lutraria gurgitis BRongniart. Palaeont. Universalis, [3], 3, 232, $232 \mathrm{a}$.

Cox, Leslie Reginald (1935): The Triassic, Jurassic and Cretaceous Gastropoda and Lamellibranchia of the Attock district. Palaeont. Indica, N. S., 20, Mem. 5, 1-27, 
pls. 1, 2.

(1935a): Cretaceous Gastropoda and Lamellibranchia. in "The Mesozoic palaeontology of British Somaliland". 198-204, pls. 22, 23.

(1937): Notes on Jurassic Lamellibranchia. I. On the occurrence of the genus Palaeoneilo in the Jurassic of Great Britain. Proc. Malacol. Soc. London, 22, (4), 190-193, pl. 15.

(1937a) : Op. cit. II. on Indogrammatodon, a new subgenus from the Jurassic of the Indo-Pacific province. Ibid., 22, (4), 194-198, pls. 15, 16.

(1940): The Jurassic lamellibranch fauna of Kuchh (Cutch). Palaeont. Indica, [9], 3, (3), 1-157, pls. 1-10.

(1943): The English upper Lias and Inferior Oolite species of Lima. Proc. Malacol. Soc. London, 25, (5-6), 151-187, pls. 6-29.

(1946): Tutcheria and Pseudopis, new lamellibranch genera from the Lias. Ibid., 27, (1), 34-48, pls. 3, 4 .

(1952): The Jurassic lamellibranch fauna of Cutch (Kachh). Palaeont. Indica, [9], 3, (4), 1-128, pls. 1-10.

(1952a): Cretaceous and Eocene fossils from the Gold Coast. Bull. Geol. Surv. Gold Coast, 17, 1-68, pls. 1-5.

(1952b): Notes on the Trigoniidae with outline of a classification of the family. Proc. Malacol. Soc. London, 29, (2-3), 45-70, pls. 3, 4.

(1954): Taxonomic notes on Isognomonidae and Bakevelliidae. Ibid., 31, (2), 46-49.

(1954a): Lower Cretaceous Mollusca from Point-à-Pierre, Trinidad. Jour. Paleont., 28, (5), 622-636, pls. 64-67.

(1960): Thought on the classification of the Bivalvia. Proc. Malacol. Soc. London, 34, (2), 60-88.

(1961): The molluscan fauna and probable Lower Cretaceous age of the Nantarra formation of Western Australia. Commonw. Australia, Dept. Nat. Develop., Bureau Min. Res. Geol. and Geophys., Bull., 61, 1-53 (7pls. incl.).

(1962): New genera and subgenera of Mesozoic Bivalvia. Palaeontology, 4, (4) , 592-598.

(1964): Notes concerning the taxonomy and nomenclature of fossil Bivalvia (mainly Mesozoic). Proc. Malacol. Soc. London, 36, (1), 39-48, pl. 1.

and Maubeuge, Pierre L. (1950): Révision de la faune de mollusques de l'horizon des "Stipites" du Larzac. (Bathonien saumâtrea). Mém. Soc. d'Études Paléont. Palethnogr. Provence, 2, (4), 1-12 (2pls. incl.).

Cragin, Francis Whittemore (1893): A contribution to the invertebrate paleontology of the Texas Cretaceous. Texas Geol. Surv., 4th Ann. Rept., 1892, (2), 139-294, pls. 24-46.

(1905) : Paleontology of the Malone Jurassic formation of Texas. U.S. Geol. Surv., Bull., 266, 1-109, pls. 1-29.

CrickMAY, C. H. (1930): The Jurassic rocks of Ashcroft, British Columbia. Univ. California publ., Dept. Geol. Sci., Bull., 19, (2), 23-74, pls. 2-7, 1 map.

-_ (1933): Mount Jura investigation. Bull. Geol. Soc. America, 44, 895-926, pls. 23-34.

DAmes, W. (1873) : Ueber Ptychomya. Zeit. deutch. geol. Gesell., 25, 374-382, pl. 12.

Dartevelle, E. and Freneix, Suzanne (1957): Mollusques fossiles du crétacé de la côte occidentale d'Afrique du Cameroun à l'Angola. II. Lamellibranches. Ann. Musée roy. Congo Belge, [8], 20, 1-271, pls. 1-35.

Dechaseaux, Colette (1936): Limidés jurassiques de l'Est du bassin de Paris. Mém. Musée roy. d'Hist. nat. Belgique, [2], 8, 1-58, pls. 1-3.

(1936a): Pectinidés jurassiiques de l'est du bassin de Paris. Ann. Paléont., 25, 1-148, pls. 1-10. 
Dickins, J. M. (1956): Permian pelecypods from the Carnarvon basin, Western Australia. Commonw. Australia, Dept. Nat. Develop., Bureau Min. Res. Geol. Geophys. Bull., 29, 1-42, pls. 1-6.

(1963) : Permian pelecypods and gastropods from Western Australia. Ibid., 63, $1-150$, pls. $1-26$.

Dietrich, W. O. (1933): Zur Stratigraphie und Palaeontologie der Tendaguruschichten. Palaeontographica, Supple. 7, (2), (2), 1-86, pls. 1-12.

(1936): Utber den stratigraphischen Wert mesozoischer Mollusken (Trajanella, Gastrop.). Zeit. deutsch. geol. Gesell., 88, (6), 399-402.

(1938): Lamellibranquios cretacicos de la Cordillera oriental. In "Estudios geol. paleont. Cordillera orient. Colombia". 81-108, pls. 15-22. Bogota.

Douvillé, Henri (1916): Le Crétacé et l'Eocène du Tibet central. Palaeont. Indica, N. S., 5, Mém. 3, 1-52, pls. 1-16.

Drouet, C. (1825): Sur un nouveau genre de coquille de la famille des Arcacées et description d'une nouvelle espèce de Modiole fossile. Mém. Soc. Linné. Paris, 3, 183-192, pl. 8. (not seen)

Etheridge, J. Jr. (1902) : The Cretaceous Mollusca of South Australia and the northern territory. Mem. Roy. Soc. South Australia, 2, (1), 8-39.

Finlay, H. J. and Marwick, J. (1937): The Wangaloan and associated molluscan faunas of Kaitangata-Green island subdivision. New Zealand Geol. Surv., Palaeont. Bull., 15, 1-140, pls. 1-18.

Fischer, P. (1880-1887): Manuel de conchyliologie. xxiv+1369pp., 23pls. Paris.

Fletcher, H. O. (1946): New Lamellibranchia from the Upper Permian of Western Australia. Rec. Australian Museum, 21, 395-405.

Forbes, Edward (1845): Catalogue of Lower Greensand fossils in the Museum of the Geological Society. Part 1. Acephala Lamellibranchiata. Quart. Jour. Geol. Soc., $1,237-250$.

Freneix, Suzanne (1958): Contribution à l'étude des lamellibranches du Crétacé de Nouvelle-Calédonie. Sciences de la Terre, 4, (3-4), 153-207, pls. 1-3. (1959): Lamellibranches du Crétacé supérieur de France (Protobranches, Prionodontes, Dysodontes (pars)). 84e Congrès des Soc. Savantes, 175-248.

FUJII, Koji (1954): Stratigraphy and geological structure of the Usuki area, Oita Prefecture, Kyushu (1). Jour. Geol. Soc. Japan, 60, (709), 413-427, pls. 5, 6. (in Japanese with English abstract)

GabB, William More (1864): Description of the Cretaceous fossils. Palaeontology of California, 1, (4), 55-236, pls. 9-32.

(1869): Cretaceous and Tertiary fossils. Ibid., 2, 1-299, pls. 1-36.

Gardner, Julia A. (1916): Systematic paleontology. Mollusca. In Clark et al.: Upper Cretaceous, 371-733, pls. 12-45. Maryland Geol. Surv.

GeINITZ, A. (1872-1873) : Das Elbthalgebirge in Sachsen. Palaeontographica, 20, (1), 169-206 (1872), 207-236 (1873); (2), 29-52 (1872), 53-72 (1873).

Gigout, Marcel (1951): Études géologiques sur la Méséta marocaine occidentale (Arrière-pays de Casablanca, Mazagan et Safi). Div. Mines et Geol., Serv. Geol. Maroc, Notes et Mém., 86, 1-494, pls. 1-18.

GILLET, S. (1921): Étude des lamellibranches du calcaire à Spatangues. Bull. Soc. de l'Yonne, 75. (not seen)

(1924): Révision du sous-genre Neithea Drouet. Bull. Soc. géol. France, [4], 24, (3-4), 115-122.

(1924a-1925): Études sur les lamellibranches néocomiens. Mém. Soc. geol. France, N. S., 1, (3-4), 1-224, pls. 1, 2; 2, (1), 225-339.

Goldfuss, August (1833-1840): Petrefacta Germaniae. Theil 2, 512pp., pls. 72-165. Düsseldorf.

HABE, Tadashige (1951-1953): Genera of the Japanese shells. Pts. 1-4. 326 pp. (in 
Japanese)

(1961): Coloured illustrations of the shells of Japan (II) . xii+183pp., 66pls. Hoikusha Book Co., Osaka. (in Japanese)

HASE, Akira (1960): The Late Mesozoic formations and their molluscan fossils in west Chugoku and north Kyushu. Jour. Sci., Hiroshima Univ., [C], 3, (2), 281342, pls. 31-39.

HataI, Kotora (1951): A Lower Cretaceous Teredo. Short Papers, Inst. Geol. Pal. Sendai, 3, 29-32, pl. 1.

Hayami, Itaru (1957): Liassic Gervillia and Isognomon in Japan. Japan. Jour. Geol. Geogr., 28, (1-3), 95-106, pls. 6, 7.

(1958): A review of the so-called Liassic "cyrenoids" in Japan. Obid., 29, (1-3), 11-27, pls. 2, 3 .

(1959): Late Jurassic isodont and myacid pelecypods from Makito, central Japan. Ibid., 30, 151-167, pl. 13.

(1959a): Lower Liassic lamellibranch fauna of the Higashinagano formation in wset Japan. Jour. Fac. Sci., Univ. Tokyo, [2], 12, (1), 31-84, pls. 5-8.

(1960): Pelecypods of the Jusanhama group (Purbeckian or Wealden) in Hashiura area, northeast Japan. Japan. Jour. Geol. Geogr., 31, (1), 13-22, pl. 3. (1960a): Jurassic inoceramids in Japan. Jour. Fac. Sci., Univ. Tokyo, [2], 12, (2), 277-328, pls. 15-18.

(1961): On the Jurassic pelecypod faunas in Japan. Ibid., [2], 13, (2), 243343 , pl. 14 .

(1962): On the dentition formulae of heterodont pelecypods. "Fossils" (Kaseki), (4), 67-78. (in Japanese)

, Matsumoto, Tatsuro and Asano, Kiyoshi (1963) : A survey of the fossils from Japan illustrated in classical monographs. Part VIII. E. NAUMANN and M. Neumayr: Zur Geologie und Paläontologie von Japan. Palaeont. Soc. Japan, 25th Anniv. Vol., 33-36, pls. 52, 53.

, Sugita Munemitsu and Nagumo, Yoshihiro (1960): Pelecypods of the Upper Jurassic and Lowermost Cretaceous Shishiori group, Northeast Japan. Japan. Jour. Geol. Geogr., 31, (1), 85-98, pl. 8.

and NAKAI, Isao (1965): On a Lower Cretaceous pelecypod, "Cyrena naumanni”, from Japan. Trans. Proc. Palaeont. Soc. Japan, N. S., 59, 114-125, pls. $13,14$.

Holdhaus, K. (1913): Fauna of the Spiti shales (Lamellibranchiata and Gastropoda). Palaeont. Indica, [15], 4, (2), 397-456, pls. 94-100.

Holzapfel, E. (1889): Die Mollusken der Aachener Kreide. III. Classe Lamellibranchiata. Palaeontographica, 35, 139-263, pls. 8-29.

Hukuti, Seizi (1941): Geology of the Oti basin, Kôti Prefecture. Jour. Geol. Soc. Japan, 48, (579), 547-559.

ICHIKAWA, Koichiro (1958) : Zur Taxionomie und Phylogenie der triadischen „Pteriidae" (Lamellibranch.) mit besonderer Berücksichtigung der Gattungen Claraia, Eumorphotis, Oxytoma und Monotis. Palaeontographica, 111, (A), 131-212, pls. 21-24.

and MAeda, Yasuo (1958): Late Cretaceous pelecypods from the Izumi group. Part 1. Cucullaeidae (Pleurogrammatodon, nov., Nanonavis and Indogrammatodon). Jour. Inst. Polytec., Osaka City Univ., [G], 3, 61-74, pls. 1, 2. and - (1958a) : Op. cit. Part 2. Orders Taxodontida, Prionodontida, Dysodontida, Desmodontida and Adapedontida. Ibid., [G], 4, 71-122, pls. 3-7. and - (1963) : Op. cit. Part 3. Order Heterodontida (1). Jour. Geosci., Osaka City Univ., 7, (5), 113-136, pls. 8-11.

IMLAY, Ralph W. (1940): Neocomian faunas of northern Mexico. Bull. Geol. Soc. America, 51, (1) , 117-190, pls. 1-21. 
(1940a) : Upper Jurassic pelecypods from Mexico. Jour. Palaeont., 14, (5), $393-411$, pls. $50-56$.

(1961): Characteristic Lower Cretaceous megafossils from northern Alaska. U.S. Geol. Surv., Prof. Paper, 335, 1-74, pls. 1-24.

IredAle, Tom (1931): Australian molluscan notes, no. 1. Australian Museum Records, 18, (4), 201-235, pls. 22-25.

(1939): Great Barrier Reef expedition 1928-1929, Scientific reports, Vol. 5, No. 6. Mollusca Part 1. 209-425, pls. 1-7. British Museum (Nat. Hist.)

IWASAKI, Yasuhide (1963) : Pseudamiantis, a pelecypod genus. Trans. Proc. Palaeont. Soc. Japan, N. S., 51, 91-101, pls. 14-15.

JAWORSKI, E. (1914): Beiträge zur Kenntnis der Lias-Volen Südamerikas und der Stammesgeschichte der Gattung Vola. Palaeont. Zeitschr., 1, 273-320.

JukEs-Browne, A. J. (1908): On the genera of Veneridae represented in the Cretaceous and older Tertiary deposits. Proc. Malacol. Soc. London, 8, (3), 148-177, pl. 6.

Kamada, Yasuhiko (1952): On some species of Cyclina from Japan and Korea. Trans. Proc. Palaeont. Soc. Japan, N. S., 6, 167-173, pl. 15.

KAтTo, Jiro (1961): Explanatory text of the geologic and mineral resource map of Kochi Prefecture. 129pp., 7pls. Kochi Prefecture. (in Japanese)

KeEn, A. Myra (1937) : Nomenclatural units of the pelecypod family Cardiidae. Bull. Musée roy. d'Hist. nat. Belgique, 13, (7), 1-22.

(1950): Outline of a proposed classification of the pelecypod family Veneridae. Conch. Club South Calif. Minutes, 111, 6-8.

(1954): Five new species and a new subgenus in the pelecypod family Cardiidae. Bull. Amer. Paleont., 35, (153), 1-22, pl. 1.

KEEPING, W. (1883): The fossils and palaeontological affinities of the Neocomian deposits of Upware and Brickhill. 167pp., 8pls. Cambridge.

Kimura, Toshio (1951): Some pectinids and a limid from the Jurassic Torinosu group in Japan. Jour. Fac. Sci., Univ. Tokyo, [2], 7, (7), 377-350, pl. 1.

(1956): Some pelecypods from the Upper Jurassic Torinosu group in Kochi Prefecture, Japan. Jour. Earth Sci., Nagoya Univ., 4, (2), 80-90, pl.1.

Kitchin, F. L. (1908): The invertebrate fauna and palaeontological relations of the Uitenhage series. Ann. South African Museum, 7, 21-250, pls. 2-11.

KobAyASHI, Teiichi (1954): Studies on the Jurassic trigonians in Japan. Part 1, Preliminary notes. Japan. Jour. Geol. Geogr., 25, (1-2), 61-80.

(1957): Nipponitrigonia and Rutitrigonia in Japan. Trans. Proc. Palaeont. Soc. Japan, N. S., 26, 51-61, pls. 10, 11.

and Nakano, Mitsuo (1957): On the Pterotrigoniinae. Japan. Jour. Geol. Geogr., 28, (4), 219-238, pls. 16, 17.

and - (1958): The Lower and Middle Cretaceous trigonians in Wakayama, Oita and Kumamoto Prefectures, west Japan. Ibid., 29, (1-3), 139-152, pls .11-12.

and SUzukI, Kôiti (1936): Non-marine shells of the Naktong-Wakino series. Ibid., 13, (3-4), 234-257, pls. 27-29.

and - (1939): The brackish Wealden fauna of the Yoshimo bed in Prov.

Nagato, Japan. Ibid., 16, (3-4), 213-224, pls. 13, 14.

and TAmura, Minoru (1955): Studies on the Jurassic Trigonians in Japan. Part 4. The Myophorellinae from north Japan. Ibid., 26, (1-2), 89-103, pls. 5, 6.

KRENkel, E. (1910): Die untere Kreide von Deutsch-Ostafrika. Beitr. Paläont. Geol. Österr.-Ungarns, 23, 201-250, pls. 20-23.

KURODA, Tokubei (1932-1935): A list of the genera of Japanese Mollusca, Parts 1-6. Venus, 3, (5), 282-289; 4, (1) , 44-54; 4, (3), 184-191; 4, (4), 258-265; 4, (5), $319-330 ; 5,(2-3), 123-141$. (in Japanese) 
(1933): Gastropoda and Lamellibranchiata. Iwanami Lecture Series, Geol. and Palaeont., 3, 1-74. (in Japanese)

LANGE, Erics (1914): Die Brachiopoden, Lamellibranchiaten und Anneliden der Trigonia schwarzi-Schicht, nebst vergleirhender Übersicht der Trigonien der gesamten Tendaguruschichten. Archiv. für Biontologie, 3, (4), 191-289, pls. 1522.

Leymerie, A. (1842): Mémoire sur le terrain crétacé du départment de l'Aube. '2e partie. Mém. Soc. géol. France, 5, (1), 1-34, pls. 1-18.

LoRIOL P., DE and GilliḱRON, V. (1869): Monographie paléontologique et stratigraphique de l'etage Urgonien inferieur du Landeron (Canton de Neuchâtel). Mém. Soc. helvét. Sci. nat., 23, 1-123, pls. 1-8.

MaAs, Günther (1895): Die untere Kreide des subhercynen Quadersandstein-Gibirges. Zeitschr. deutsch. geol. Gesell., 47, 227-302, pls. 5-9.

MAEdA, Shiro (1959): On two species of Polymesoda from the Tetori group in the Hida mountains, central Japan. Trans. Proc. Palaeont. Soc. Japan, N. S., 36, 157-160, pl. 17.

(1963): Trigonioides from the Late Mesozoic Tetori group, central Japan. Ibid., N. S., 51, 79-85, pl. 12.

(1963a): On some Nipponitrigonia in Japan. Jour. College Arts and Sci., Chiba Univ., 3, (4), 503-514, pls. 1-9.

Makiyama, Jiro (1926): Tertiary fossils from north Kankyô-dô, Korea. Mem. Coll. Sci., Kyoto Imp. Univ., [B], 2, (3), 143-160, pls. 12, 13.

(1936): The Meisen Miocene of north Korea. Ibid., [B], 11, (4), 193-228, pls. 4,5 .

MARLIÈRE, René (1939): La transgression albienne et cénomanienne dans le Hainaut (Études paléontologiques et stratigraphiques). Mém. Musée roy. d'Hist. nat. Belgique, Mém. 89, 1-440, pls. 1-8.

Marwick, J. (1927) : The Veneridae of New Zealand. Trans. New Zealand Inst., 57, $567-635$, pls. $34-54$.

(1953): Divisions and faunas of the Hokonui system (Triassic and Jurassic). New Zealand Geol. Surv., Palaeont. Bull., 21, 1-141, pls. 1-17.

Matsumoto, Tatsuro (1938): Preliminary notes on some of the more important fossils among Gosyonoura fauna (Contributions to the Cretaceous palaeontology of Japan-III). Jour. Geol. Soc. Japan, 45, (532), 13-26, pls. 1, 2.

(1947): The geologic research of the Aritagawa valley, Wakayama Prefecture-A contribution to the tectonic history of the Outer Zone of Southwest Japan. Sci. Rept. Fac. Sci. Kyushu Univ., Geol., 2, (1), 1-12. (in Japanese)

(1954, ed.): The Cretaceous System in the Japanese Islands. xiv +324pp., 36pls. Japan Soc. Prom. Sci Res., Tokyo. (for 1953)

(1959) : Zonation of the Upper Cretaceous in Japan. Mem. Fac. Sci., Kyushu Univ., [D], 9, (2) , 55-93, pls. 6-11.

(1963): The Cretaceous, in Takai, F., Matsumoto, T. and Toriyama, R. (ed.): Geology of Japan. 99-128. Univ. Tokyo press.

and HARADA, Masato (1964): Cretaceous stratigraphy of the Yubari dome, Hokkaido. Mem. Fac. Sci., Kyushu Univ., [D], 15, (1), 79-115, pls. 9-11.

- Hayami, Itaru and Asano, Kiyoshi (1963): A survey of fossils from Japan illustrated in classical monographs. Part VII. M. YokoYAMA: Versteinerungen aus der japanischen Kreide. Palaeont. Soc. Japan, 25th Anniv. Volume, 27-32, pls. 44-51.

- and KANMERA, Kametoshi (1952): Guide book for geological excursions: The lower valley of the Kuma. 71pp., 6 maps. Dept. Geol., Kyushu Univ. (in Japanese)

MCLEARN, F. H. (1945) : Revision of the Lower Cretaceous of the Western Interior 
of Canada. Geol. Surv. Canada, Paper 44-17, 1-14, pls. 1-12.

MeEk, Fielding Bradford (1873): Palaeontological report. 6th Ann. Rept., U. S. Geol. Surv., Terr., 487-497.

(1874): New genus Euchondria MEEk. Amer. Jour. Sci., [3], 7, 445.

(1876): A report on the invertebrate Cretaceous and Tertiary fossils of the Upper Missouri County. U.S. Geol. Surv., Terr. Rept., 9, 1-269, pls. 1-45.

Moesch, C. (1874-1875): Monographie der Pholadomyen. Vol.1 (1874) Abhandl. scweiz. paläont. Gesell., 1, 1-78, pls. 1-26; Vol. 2 (1875) Ibid., 2, 79-135, pls. 2740.

MORRIS, J. and LYCETT, J. (1853): A monograph of the Mollusca from the Great Oolite, chiefly from Minchinhampton and the coast of Yorkshire. Pt. 2. Bivalves. 147pp., 15pls. Palaeontogr. Soc. London.

MüLleR, G. (1898): Die Molluskenfauna des Untersenon von Braunschweig und Ilsede. 1. Lamellibranchiaten und Glossophoren. Abhandl. preuss. geol. Landes., N. F., 25, 1-142, pls. 1-18.

Murchison, Roderick Impey, Verneuil, Edouard de and Keyserling, le Comte Alexandre de (1845): Géologie de la Ressie d'Eussie d'Europe et des montagnes de l'Oural. xxxii+512pp., 50pls. London and Paris.

NagaI, Kozo and Nakano, Mitsuo (1961): On the newly discovered Lower Cretaceous Nigyu formation from Nigyu in Mikame-cho, Nishiuwa-gun, Ehime Prefecture, Shikoku, Japan. Mem. Ehime Univ., Sec. II (Sci.), [D], 4, (2), 57-62.

NAGA0, Takumi (1930): On some Cretaceous fossils from the islands of Amakusa, Kyushu, Japan. Jour. Fac. Sci., Hokkaido Imp. Univ., [4], 1, (i), 1-25, pls. 1-3. (1932): Some Cretaceous Mollusca from Japanese Saghalien and Hokkaido (Lamellibranchiata and Gastropoda). Ibid., [4], 2, (1), 23-50, pls. 5-8.

(1933): A new variety of Toucasia carinata (МАTH.) from the Lower Cretaceous of Japan. Ibid., [4], 2, (2), 163-167, pls. 21, 22.

(1934): Cretaceous Mollusca from the Miyako district, Honshû, Japan. Ibid., [4], 2, (3), 177-277, pls. 23-39.

(1938) : Some molluscan fossils from the Cretaceous deposits of Hokkaido and Japanese Saghalien. Part 1. Lamellibranchiata and Scaphopoda. Ibid., [4], 4, (1-2), 117-142, pls. 14-16.

(1943) : Pholadomya from Japan. Jour. Geol. Soc. Japan, 50, (596), 153-160, pls. 12,13 .

and Otatume, K. (1938): Molluscan fossils of the Hakobuti sandstone of Hokkaido. Jour. Fac. Sci., Hokkaido Imp. Univ., [4], 4, (1-2), 31-56, pls. 1-4.

NAKANo, Mitsuo (1957): On the occurrence of Psilotrigonia in the Cretaceous of the Kwanto mountaneous land, Japan. Jour. Sci., Hiroshima Univ., [C], 2, (1), $69-71$.

(1958): Scabrotrigonians in Japan. Ibid., [C], 2, (3), 227-233, pl. 29.

(1960): Stratigraphic occurrences of the Cretaceous trigonians in the Japanese islands and their faunal significances. Ibid., [C], 3, (2), 215-280, pls. 23-30.

(1963): On the Rutitrigoniinae. Geol. Rept., Hiroshima Univ., 12, 513-529, pl. 56.

Naumann, E. and Neumayr, M. (1890): Zur Geologie und Paläontologie von Japan. Denkschr. Kaiserl. Akad. Wiss., Math.- Naturw. Cl., 57, 1-41, pls. 1-5.

Newell, Norman D. (1937-1938): Late Paleozoic pelecypods: Pectinacea. Univ. Kansas, State Geol. Surv. Kansas, 10, 1-123 (1937), pls. 1-20 (1938).

(1957): Notes on certain primitive heterodont pelecypods. American $M$ useum, Novitates, 1857, 1-14 (2 pls. incl.)

Newton, Bullen R. (1909): Cretaceous Gastropoda and Pelecypoda from Zululand. Trans. Roy. Soc. South Africa, 1, 1-106, pls. 1-9.

(1915-1916): On some Cretaceous Brachiopoda and Mollusca from Angola. 
Trans. Roy. Soc. Edinburgh, 51, (3), (15), 561-580, pls. 1, 2.

Nicol, David (1945): Genera and subgenera of the pelecypod family Glycymeridae. Jour. Paleont., 19, (6), 616-621.

(1947): Tropical American species of Glycymeris from the Tertiary of California, and a new species from Panama. Jour. Paleont., 21, (4), 346-350, pl. 50. (1950): Origin of the pelecypod family Glycymeridae. Ibid., 24, (13), 89-98, pls. 20-22.

(1954): Nomenclatural review of genera and subgenera of Cucullaeidae. Ibid., 28, (1), 96-101.

(1958): A survey of inequivalve pelecypods. Jour. Washington Acad. Sci., 48, (2), 56-62.

(1958a): Notes on priondont pelecypods. Ibid., 48, (10), 309.

North, F. K. (1951): On the type of Pseudamussium and other notes on pectinid nomenclature. Jour. Paleont., 25, (2), 231-236.

Okubo, Masahiro and Matsushima, Nobuyuki (1959): On a new species of Pachyodonta from the Akaishi mountains, central Japan. Chikyu-kagaku (Earth Science), 42, 1-4. (in Japanese)

ONUKI, Yoshio, Hase, Kotaro and Suzuki, Mitsuru (1960): On the so-called older rocks in the Omoto-Tanohata district, Iwate Prefecture, northern Kitakami massif, Japan. Jour. Geol. Soc. Japan, 66, (780), 594-604. (in Japanese with an English abstract)

and MORI, Kei (1961): Geology of the Ofunato district, Iwate Prefecture, southern part of the Kitakami massif, Japan. Ibid., 67, (794), 641-654. (in Japanese with an English abstract)

OPPENHEIM, P. (1903) : Zur Kenntnis alttertiärer Faunen in Ägypten. I. Bivalven. Palaeontographica, 30, (3), 1-164, pls. 1-17.

D’Orbigny, Alcide (1843-1847): Paléontologie française. Terrain crétacés. Vol. 3. Lamellibranches. 807pp., pls. 237-489. Paris.

(1850): Prodrome de paléontologie stratigraphique universelle des animaux mollusques et rayonnés. Vol. 1. lxi+394pp., Vol.2. 428pp. Paris.

Orlov, F. A. et al. (1960): Fundamentals of Palaeontology. Mollusca. Pelecypoda. 300pp. (44pls. incl.). Acad. Nauk, U.S. S. R., Moscow. (in Russian)

OtA, Yoshihisa (1959): Plicatounio of the Wakino formation. Trans. Proc. Palaeont. Soc. Japan, N. S., 33, 15-18, pl. 3.

(1959a): Trigonioides and its classification. Ibid., N. S., 34, 97-104, pl. 10. $(1959 \mathrm{~b})$ : On the "Nippononaia" from the Lower Cretaceous Wakino subgroup, north Kyushu, Japan. Ibid., N. S., 34, 105-110, pl. 11.

(1964): On some Cretaceous corbulids from Japan. Mem. Fac. Sci., Kyushu Univ., [D], 15, (1), 149-161, pls. 20, 21.

OYAma, Katsura (1944): Classification of the genus Propeamussium. Venus, 13, (5-8), 240-254.

PaCkard, Earl Leroy (1922): New species from the Cretaceous of the Santa Ana mountains, California. Univ. California Publ., Bull. Dept. Geol. Sci., 13, (10), 413-462, pls. $24-38$.

Peron, A. (1877) : Observations sul la faune des calcaires à echinides de Rennes-lesBains et sur quelques fossiles du terrain crétacé supérieur. Bull. Soc. géol. France, [3], 5, 499-520.

(1890-1891): Exploration scientifique de la Tunisie. Description de Mollusques fossiles des terrains crétacé de la région sur des Hauts-plateaux de la Tunisie, recueillis en 1885 et 1886 par M. Ph. Thomas. 2e partie. Pélécypodes. 105-327, pls. 15-31. Paris. (not seen)

Pervinquik̀re, L. (1910) : Ostrea carinata Lamarck, 1806. Palaeont. Universalis, [3], 2, 197, 197a, b. 
(1912): Etudes de paléontologie tunisienne. Part 2. Gastropodes et lamellibranches des terrains crétacés. Carte géol. Tunis, 1-352, pls. 1-23.

Ретнӧ, J. (1882): Die genauere Begründung und Trennung des Gattungen Neithea und Volen (Janira). Földt Kozl., 12, 187-196. (not seen)

PhilipPI, E. (1900): Beiträge zur Morphologie und Phylogenie der Lamellibranchier. II. Zur Stammesgeschichte der Pectiniden. Zeitschr. deutsch. geol. Gesell., 52, $64-117$.

Pictet, F. J. and Campiche, G. (1864-1871): Description du terrain crétacé des environs de Ste Croix. Matér. Paléont. Suisse, 3 (1864-1867), 1-557, pls. 99-139; 4 (1868-1871), 1-351, pls. 140-194.

- and Renevier, E. (1858): Description du terrain Aptien de la Perte du Rhône et des environs de Ste. Croix. 184pp., 23pls. Genève.

- and Roux, W. (1847-1853): Description des mollusques fossiles qui se trouvent dans les grès verts des environs de Gèneve. 558pp., 51pls. Gèneve.

Popenoe, W. P. (1937): Upper Cretaceous Mollusea from southern California.Jour. Paleont., 11, (5), 379-402, pls. 45-49.

(1942): Upper Cretaceous formations and faunas of southern California. Bull. Amer. Assoc. Petrol. Geol., 26, (2), 162-187.

QuenstedT, Friedrich August (1858): Der Jura. 842pp., 100pls. Tübingen.

Quenstedt, W. (1930): Die Anpassung an die grabende Lebenweise in der Geschichte der Solemyiden und Nuculaceen. Geol. Paläont. Abhandl., N. F., 18, 1-119, pls. 1-3.

Rennie, J. V. L. (1929): Cretaceous fossils from Angola (Lamellibranchia and Gastropoda). Ann. South African Museum, 28, (1), 1-54, pls. 1-5.

(1930): New Lamellibranchia and Gastropoda from the Upper Cretaceous of Pondoland (with an appendix on some species from the Cretaceous of Zululand). Ann. South African Museum, 28, (2), 159-260, pls. 16-31.

Reyment, R. A. (1955): Upper Cretaceous Mollusca (Lamellibranchia and Gastropoda) from Nigeria. Colon. Geol. Min. Res. London, 5, (2), 127-155, pls. 1-4.

Richards, Horace G. et al. (1958) : The Cretaceous fossils of New Jersey. Pt. 1. New Jersey Geol. Surv., Bureau Geol. Topogr., Bull., 61, 1-266, pls.1-46.

Roman, Frédéric and Mazeran, Pierre (1913): Monographie paléontologique de la faune du Turonien du bassin d'Uchaux et de ses dépendences. Arch. Musée hist. nat. Lyon, 12, 1-137, pls. 1-11.

RöMER, Ferdinand (1852): Die Kreidebildungen von Texas und ihre organischen Einschlüsse. 100pp., 11pls. Bonn.

RÖMER, F. A. (1839): Die Versteinerungen des nord-deutschen Oolithen-Gebirges. Ein Nachtrag. Hannover. (not seen)

Sato, Tadashi (1958): Presénce du Berriasien dans la stratigraphie de plateau de Kitakami (Japon septentrional). Bull. Soc. géol. France, [6], 8, 585-599, pl. 28. (1961): La limite jurassico-crétacée dans la stratigraphie japonaise. Japan. Jour. Geol. Geogr., 32, (3-4), 533-541, pl. 12.

SeELeY, H. G. (1861) : Notes on Cambridge palaeontology. Ann. Mag. Nat. Hist., [3], $7,116-127$, pls. $5,6$.

SEki, Takeo and Imaizumi, Rikizô (1941): Cretaceous formations at the Ofunato bay, Kesen-gun, Iwate Prefecture. Contr. Inst. Geol. Pal., Tohoku Univ., 35, 1-36.

Shimer, H. W. and SHrock, R. R. (1944): Index fossils of North America. 837pp. (303pls. incl.) New York.

Shimizu, Saburô (1931): The marine Lower Cretaceous deposits of Japan, with special reference to the ammonites-bearing zones. Sci. Rept. Tohoku Imp. Univ., $[2], 15,1-40$, pls. $1-4$.

Shumard, B. F. (1860): Description of new Cretaceous fossils from Texas. Trans. Acad. Sci. St. Louis, 1, 590-609. 
Shuto, Tsugio (1960): Cardiids from the Miyazaki group (Palaeontological study of the Miyazaki group-VII). Trans. Proc. Palaeont. Soc. Japan, N. S., 37, 209222 , pl. 25.

Sokolov, D. and Bopylevski, W. (1931): Jura und Kreidefaunen von Spitzbergen. Skrift. Svalbard Ishavet, 35, 1-151, pls. 1-14.

Sommermeier, L. (1913): Die Fauna des Aptien und Albien im nördlichen Peru. Neues Jahrb. f. Min. usw., Beil.-Bd., 36, 370-412, pls. 14, 15.

Sowerby, James and Sowerby, James de Carle (1812-1846): The mineral conchology of Great Britain. 7 vols. 648pls. Benjamin Meredith, London.

Speden, Ian G. (1960): The Jurassic age of some supposedly Triassic Mollusca described by Wilckens (1927) from Mt St Mary. New Zealand Jour. Geol. Geophys., 3, (3), 510-523.

Staesche, Carl (1926): Die Pectiniden des schwäbischen Jura. Geol. Paläont. Abhandl. Jena, N. F., 15, (1), 1-136, pls. 1-6.

Stanton, Timothy William (1894): The Colorado formation and its invertebrate fauna. U.S. Geol. Surv., Bull., 106, 1-288 (pls. 1-45 incl.). (for 1893) (1895): Contributions to the Cretaceous paleontology of Pacific coast, the fauna of the Knoxville beds. Ibid., 133, 1-132, pls. 1-20.

(1947): Studies of some Comanche pelecypods and gastropods. U.S. Geol. Surv., Prof. Paper, 211, 1-256 (pls. 1-67 incl.).

SteinmanN, Gustav (1881): Uebebr Tithon und Kreide in den peruanischen Anden. Neues Jahrb. f. Min. usw., 1881, (2), 130-153, pls. 6-8.

Stenzel, H. B. (1959): Cretaceous oysters of southwestern North America. Congreso Geol. Intern., XX Sesion, Mexico. El sistema cretacico un symposium sobre el cretacico en el hemisferio occidental y su correlation. Tom. 1. Etapas y correlation, 15-37.

Stephenson, Lloyd William (1914): Cretaceous deposits of the eastern Gulf region and species of Exogyra from the eastern Gulf region and the Carolinas. U.S. Geol. Surv., Prof. Paper, 81, 1-55, pls. 1-21.

(1923): The Cretaceous formations of North Carolina. Pt. 1. Invertebrate fossils of the Upper Cretaceous formation. North Carolina Geol. Econ. Surv., Bull., 5, 1-604, pls. 1-102.

(1941): The larger invertebrate fossils of the Navarro group of Texas. Texas Univ. Publ., 4101, 1-641 (pls. 1-95 incl.).

(1953) : Larger invertebrate fossils of the Woodbine formation (Cenomanian) of Texas. U.S. Geol. Surv., Prof. Paper, 242, 1-226, pls. 8-59. (for 1952)

Stewart, Ralph Bentley (1930): GabB's California Cretaceous and Tertiary type lamellibranchs. Acad. Nat. Sci. Philadelphia, Spec. Publ., 3, 1-314, pls. 1-17.

Stoliczka, Ferdinand (1871) : Cretaceous fauna of southern India. Vol. 3. Pelecypoda. Palaeont. Indica, [6], 3, i-xxii, 1-537, pls. 1-50.

Stoyanow, Alexander (1949): Lower Cretaceous stratigraphy in southern Arizona. Geol. Soc. America, Mem., 38, 1-169, pls. 1-27.

SUzuKI, Kôiti (1941): A new naiad, Unio (Nippononaia) ryosekiana, n. subgen. and n. sp. from the Lower Cretaceous of Japan. Jour. Geol. Soc. Japan, 48, (575), 410-413.

(1949): Development of the fossil non-marine molluscan faunas in eastern Asia. Japan. Jour. Geol. Geogr., 21, (1-4), 91-133.

TAKEDA, Hiroyuki (1953): The Poronai formation (Oligocene Tertiary) of Hokkaido and south Sakhalin. Hokkaido Assoc. Coal Min. Techn., Geol. Sec., (3), 1-103, pls. 1-18.

TAKEI, Kensaku (1963) : Stratigraphy and geological structure of the Cretaceous system in the eastern part of the Sanchû graben, Kwanto mountainland. Jour. Geol. Soc. Japan, 69, (810), 130-146. (in Japanese with an English abstract) 
Tamura, Minoru (1959): Trigoniidae, Ostreidae, Bakevelliidae, Pteriidae, Cardiidae and Astartidae from the Upper Jurassic Sakamoto formation in central Kyushu, Japan. Trans. Proc. Palaeont. Soc. Japan, N. S., 33, 23-32, pl. 5.

(1959a): Taxodonta and Isodonta from the Upper Jurassic Sakamoto formation in central Kyushu, Japan. Ibid., N. S., 34, 53-65, pl. 6.

(1959b): Taxodonta and Isodonta from the Jurassic Soma group in north Japan. Ibid., N. S., 36, 168-180, pl. 19.

(1960): Heterodont and other pelecypods from the Upper Jurassic Soma group, Japan. Ibid., N. S., 39, 285-292, pl. 33.

TAte, Ralph (1868): Appendix to the Manuel of Mollusca of S. P. Woopward, A. L. S. 81pp. Lockwood \& Co., London.

Tavani, G. (1948): Fauna malacologica cretacea della Somalia e dell'Ogaden. Palaeont. Italica, 43, 83-153, pls. 10-20.

ThIELE, Johannes (1935): Handbuch der systematischen Weichtierkunde. Bd. II. i-v, 779-1154. Gustav Fischer, Jena.

Tokuyama, Akira (1959): "Bakevellia" and "Edentula" from the Late Triassic Mine series in west Japan. Trans. Proc. Palaeont. Soc. Japan, N. S., 35, 147-155, pl. 16.

Toula, Franz (1882): Grundlinien der Geologie des westlichen Balkan. Denkschr. Kaiserl. Akad. Wiss., Math.- Naturw. Cl., 44, (2), 1-56, pls. 1-4, 1 map.

(1888): Geologische Untersuchungen im centralen Balkan. Ibid., 55, (2), 1-108, pls. 1-9, 1 map.

Ueda, Yoshiro (1963): Two new species of Opis from the Cretaceous of Japan. Trans. Proc. Palaeont. Soc. Japan, N. S., 50, 70-80, pl. 11.

Van de Poel, Luc (1959): Faune malacologique de Hervien. Troisieme note (première partie). Bull. Inst. roy. Sci. nat. Belgique, 35, (15), 1-26; Troisieme note (seconde partie). Ibid., 35, (16), 1-28, pl. 1.

VAN DER WEIJDEN, W. J. M. (1943): Die Macrofauna der Hervenschen Kreide. Meded. Geol. Stichting, [C], 2, (1), 1-139, pls. 1-15.

Vialov, O. S. (1937): Sur la classification des ostréidés et leur valeur stratigraphique. C. R. Intern. Zool. Congress, 12, Lisbonne 1935, 2, 1627-1639.

Vokes, Harold Ernest (1946): Contributions to the paleontology of the Lebanon mountains, Republic of Lebanon. Part 3. The pelecypod fauna of the "Olive locality" (Aptian) at Abeih. Bull. American Mus. Nat. Hist., 87, (3), 143-215, pls. 1-10.

WADE, Bruce (1926): The fauna of the Ripley formation on Coon Creek, Tennessee. U.S. Geol. Surv., Prof. Paper, 137, 1-272, pls. 1-72.

Weaver, Charles E. (1931): Paleontology of the Jurassic and Cretaceous of west central Argentina. Mem. Univ. Washington, 1, i-xv, 1-469, pl. 1-62.

White, C. A. (1887): On new generic forms of Cretaceous Mollusca and their relation to other forms. Acad. Nat. Sci. Philadelphia. Proc., 39, (1), 32-37, pl. 2.

Whiteaves, J. F. (1876-1903) : Mesozoic fossils. Vol.v. Part 1 (1876), 1-92, pls. 1-10, 1 map; Part 2 (1879), 93-190, pls. 11-20; Part 3 (1884), 191-262, pls. 21-32; Part 4 (1900), 263-307, pls. 33-39; Part 5 (1903), 309-415, pls. 4051. Geol. Surv. Canada.

Whitfield, Robert Parr (1885): Brachiopoda and Lamellibranchiata of the Raritan clays and Greensand marls of New Jersey. U.S. Geol. Surv., Monogr., 9, i-xx, $1-338$, pls. $1-35$.

Whitney, F. L. (1911): Fauna of the Buda limestone. Bull. Texas Univ., 184, $1-55$, pls. $1-13$.

Wilckens, Otto (1927): Palaeontology of the New Zealand Trias. New Zealand Geol. Surv., Palaeont. Bull., 12, 1-viii, 1-65, pls.1-10.

WollemanN, A. (1896): Kurze Uebersicht über die Bivalven und Gastropoden des 
Hilsconglomerats bei Braunschweig. Zeitschr. deutsch. geol. Gesell., 48, 830-853. (1900): Die Bivalven und Gastropoden des deutschen und holländischen Neocoms. Abhandl. preuss. geol. Landes., N. F., 31, 1-180, pls. 1-8.

Woods, Henry (1899-1913): A monograph of the Cretaceous Lamellibranchia of England. Vol. 1 (1899-1903), xliii+227pp., 42pls.; Vol. 2 (1904-1913), 473pp., 62pls. Palaeontogr. Soc. London.

(1906): The Cretaceous fauna of Pondoland. Ann. South African Mus., 4, 275-350, pls. 33-44.

(1917): The Cretaceous faunas of the north-eastern part of the South Island of New Zealand. New Zealand Geol. Surv., Palaeont. Bull., 4, 1-41, pls. 1-20.

YABE, Hisakatsu (19.27): Cretaceous stratigraphy of the Japanese islands. Sci. Rep. Tohoku Imp. Univ., [2], 11, (1), 27-100, pls. 3-9.

and Nagao, Takumi (1926): Fossil Mollusca from the Cretaceous of the Sanchu graben, Kwanto mountainland. Chikyu (The Earth), 5, (5), 429-438, pl. 9. (in Japanese)

and - (1926a): Paraecaprotina, nov. gen. from the Lower Cretaceous of Japan. Sci. Rep. Tohoku Imp. Univ., [2], 9, (1), 21-24, pl. 7.

and (1928): Cretaceous fossils from Hokkaido: Annelida, Gastropoda and Lamellibranchiata. Ibid., [2], 9, (3), 77-96, pls. 16, 17.

, - and Shimizu Saburô (1926): Cretaceous Mollusca from the Sanchu graben in the Kwanto mountainland, Japan. Ibid., [2], 9, (2), 33-76, pls. 12-15.

YEHARA, Shingo (1915): The Cretaceous trigoniae from Miyako and Hokkaido. Ibid., [2], 2, 35-44, pls. $1,2$.

(1920): A pachyodont lamellibranch from the Cretaceous deposits of Miyako in Rikuchû. Jour. Geol. Soc. Tokyo, 27, (321), 39-44, pls. 11, 12.

(1921): On some new species of Trigonia from the Lias of Prov. of Nagato and the Cretaceous of Prov. of Awa. Ibid., 28, (3.29), 7-11, pl. 5.

(1923): Cretaceous Trigoniae from Southwestern Japan. Japan. Jour. Geol. Geogr., 2, (3), 59-84, pls. 8-13.

Yoкоуама, Matajiro (1890): Versteinerungen aus der japanischen Kreide. Palaeontographica, 36, 159-202, pls. 18-25.

(1904): On some Jurassic fossils from Rikuzen. Jour. Coll. Sci., Imp. Univ. Tokyo, 18, (6), 1-13, pls. 1, 2.

(1927): Fossil Mollusca from Kaga. Jour. Fac. Sci. Imj. Univ. Tokyo, [2], 2, (4), 165-182, pls. 47-49.

Zittel, K. A. (1865-1866) : Die Bivalven der Gosaugebilde in den nordostlichen Alpen. Denkschr. Akad. Wiss. Wien, 24, (2), 105-177; 25, (2), 77-198.

\section{Index of Genera and Species}

Names of genera, subgenera and species described (in italic type) or discussed (in roman type) in Part I (Mem. Fac. Sci., Kyushu Univ., Ser. D, Geol., Vol. 15, No. 2, pp. 221-349, pls. 27-52, 1965), Part II (Ibid., Ser. D, Geol., Vol. 17, No. 2, pp. 73-150, pls. 7-21, 1965) and Part III (this part) are alphabetically listed below. Plates are indicated by italic type with figure-number $(s)$ in parentheses.

A

Acesta, I, 327

acuticarinata, Cucullaea, I, 242, 27(15), $28(1-10)$

adkinsi, Astarte, II, 83

aequicostata, Neithea, I, 284, 292, 293
Agapella, II, 144

Aguileria, I, 262

akatsui, Astarte (Yabea), II, 95, 9 (25) , 14 (10-11)

aketoensis, Neithea, I, 294, 309, 43 
alaeformis, Gervillaria, I, 270

alata, "Vola", I, 285

alatior, Gervillaria, I, 271

aliquantula, Cyprina, II, 137

aliquantula, Isocyprina, II, 137, 19 (89)

alpina, Neithea, I, 289, 304

altissimum, Offadesma, III, 169, 26 (1)

amakusensis, Glycymeris, I, 253

amakusensis, Opis (Opis), II, 106

amanoi, Neithea (Neithea), I, 288, 299, $41(8-10), 42(1-4)$

amanoi, Pseudocardia, II, 79, $7(4-7)$, $15(1-2)$

amaxensis, Cucullaea, I, 247

Amphidonte, I, 342, 343, III, 248

Amygdalum, I, 257

Anatina (Cercomya) sp., III, 166

anglica, Plectomya, III, 169

anglica, Plectomya aff., III, 169, 25 (16)

angoliensis, Neithea, I, 288

Anofia, II, 146

Anthonya, II, 109

Antiquilima, I, 329

Bakevellia, I, 273

Bakevelloides, I, 262

Barbatia, I, 249

Barbatia sp., I, 249, 28 (16)

bellula, Neithea, I, 289

Callistina, II, 146

Calva, II, 146

canaliculata, Gryphaea, I, 337

cantabridgiensis, Astarte, II, 87

cantiana, Anthonya, II, 112

"Cardita" (?) sp., II, 80, 7 (8)

carinata, Lopha (Arctostrea), I, 340, 49 (13)

carinata, Ostrea, I, 340

carinatus, Nanonavis, I, 240

carinifera, Lyonsia, III, 172

carteroni, Anatina, III, 168

carteroni, Arca, I, 249

carteroni, Tellina, II, 126, 127

Cassianella, I, 263

caudata, Goniomya, III, 165

Ceratostreon, I, 342, 343, 345

Cercomya, III, 166

Chimela, II, 146

Chlamys, I, 310
Aphrodina, II, 146

apicalis, Anthonya, II, 112

aptiana, Monia, I, 335, 47 (10-11)

aptiensis, Arca, I, 246

Aptolinter, I, 246

arcacea, Crassatella, II, 109

archiaci, Goniomya, III, 165

Arctopratulum, II, 122

Arcullaea, I, 244

argentina, Eriphyla, II, 101, 104

aritagawana, Laternula, III, 168

aritagawana, Plectomya, III, 168, 25

$(14,15), 26$ (2)

asperrima, Plicatula, I, 323, 324

Astarte, II, 80

Astate (Astarte?) sp., II, 88

atava, Neithea, I, 291, 306, 307, 308

atava, Neithea (Neithella) cf., I, 307, $44(1-4)$

Atrina, I, 283

atriniformis, Plesiopinna, I, 283

attockensis, Neithea, I, 288, 299

awajianus, Indogrammatodon, I, 240

B

bisolaris, "Cardium", II, 122

bodei, Astarte, II, 92, 94

Brachidontes, I, 258

brevitesta, Pholadomya, III, 158, 23 (2)

$\mathrm{C}$

choshiensis, Isognomon (Isognomon)

I, 279, 39 (1)

Circe, II, 140

claxbiensis, Astarte, II, 92

collombi, Pholadomya, III, 159

cometa, Neithea, I, 291, 292

conica, Exogyra, I, 345

connectans, Pholadomya, III, 161

conradi, Pecten, I, 319

constantii, Cardita, II, 78

Corimya, II

cornueliana, Anatina, II, 109, 112

cornueliana, Cucullaea, I, 243

cornueliana, Pholadomya, III, 158

cornueliana, Pholadomya aff., III, 162

corrugata, Dosiniopsis, II, 145, 148

corrugata, Nagaoella, II, 148, 19 (12-

15), 20 (1-12)

corrugata, Nagaoella aff., II, 150, 20

(13) 
corpulentum, Cardium, II, 125

corpulentum, Laevicardium (?), II, 125, 15 (11)

costata, Astarte (Astarte), II, 85, 8 (1-2)

costata, Astarte subsenecta var., II, 85

Costocyrena, II, 130

cottaldina, Cardita, II, 80

cottaldium, Cardium, II, 122

cowperi, Propeamussium, I, 321

crassitesta, Pterinella, I, 265

Crenotrapezium, II, 128, 129

crenulata, "Callista" (Pseudamiantis),

II, 147

cretacea, Myoconcha, II, 76

Cryptopecten, I, 312

decemcostata, Neithea, I, 294

decipiens, Neithea, I, 293

decoratus, Spondylus, I, 324, 47 (4-9), $52(6)$

delta, Myoconcha, II, 77

demissum, Entolium, I, 316

denisonensis,, Protocardia, II, 123

densicostata, Ptychomya, II, 141, 21 (1-4)

densilineata, Glycymeris (Hanaia), I, $251,29(1-15)$

deshayesiana, Neithea, I, 294

elegans, Eriphyla, II, 99, 104

elegans, Lyonsia, III, 172

elongata, Anthonya, II, 112

enigma, Gervillaria, I, 272

Ensio, II, 140

Entolium, I, 314

Eomiodon, II, 128, 129, 131

Eonavicula, I, 249

falcatus, Modiolus, I, 255, 30 (1-2)

falcatus, Mytilus, I, 256

Fatina, I, 349

faucignyana, Neithea, I, 290

faujasi, Neithea, I, 290

favrinus, Hinnites, I, 313

favrinus, Prohinnites cf., I, 313, 44 (9)

farryi, Plicatula, I, 324

ficalhoi, Neithea (Neithea), I, 289, 302,
Ctenoides, I, 330

Cucullaea, I, 242

cunabula, Liostrea sp. ex gr., I, 336, $49(7)$

cuneatus, Eomiodon, II, 133

cuneiformis, Panis, I, 272

Cuneolus, I, 256

cultriformis, Anthonya, II, 109, 112

Cuspidaria, III, 172

Cyathodonta, III, 170

Cyclina, II, 147

Cyclinorbis, II, 147

Cyclorisma, II, 146

cymbula, Malletia (Neilo), I, 234

Cyprimeria, II, 146

Cyrenopsis, II, 128

D

Dicranodonta, I, 254

diluviana, Ostrea, I, 340

dolobra, Rasatrix, II, 149

Dosiniopsella, II, 146

Dosiniopsis, II, 145

dowlingi, Dicranodonta, I, 255

Dozyia, II, 98, 101

dumbeae, Nemocardium, II, 123

duplicicosta, Neithea, I, 290

dutemplei, Neithea, I, 288

dutrugei, Neithea, I, 294

E

Eotrapezium, II, 129

Eriphyla, II, 96

esmarki, Pholadomya, III, 159

Euchondria, I, 262

euplocus, Pecten (Camptonectes), I, 329

Exogyra, I, 342

ezoensis, Lucina (Myrtea), II, 115

F

$42(5-16)$

Fimbria, II, 115

Fimbria sp., II, 115

fittoni, Cucullaea, I, 243

forbesiana, Gervillia (Gervillia), I, 276, $37(7-8), 38(1-5)$

fredericksburgensis, Neithea, I, 289

Freiastarte, II, 88

fujii, Cucullaea, I, 246, 28 (14-15) 
Gafrarium, II, 140

georgetownensis, Neithea, I, 289

germaricus, Pecten, I, 314

Gervillaria, I, 262, 268

Gervillia, I, 276

Gervillia (?) sp., I, 257

gibbosa, Neithea, I, 290, 306

gibbosus, Spondylus, I, 325

gilleti, Scambula, II, 110

Glans, II, 80

Globocardium, II, 116

Glycymeris, I, 250

Glycymerita, I, 250, 254

goliath, Plagiostoma (Acesta), I, 328

goliathiforme, Plagiostoma (Acesta), I,

habunokawense, Variamussium, I, 321

haginoensis, Opis (Opis), II, 106

haginoensis, Opis (Trigonopis), II, 106 haipensis, Glycymeris (Glycymerita?)

I, 254, 29 (16-17)

haldonensis, Opis (Opis), II, 106

haliotoidea, Exogyra, I, 345

Hanaia, I, 250

hanaii, Plicatula, I, 322, 47 (1-3)

haradae, Avicula, I, 269

haradae, Gervillia, I, 269

haradae, Gervillaria, I, 269, 35 (2-6), $36(1), 37(2)$

ibbetsoni, Cardium, II, 120, 123

Idonearca, I, 244

ichikawai, Isognomon (Melina), I, 280, $38(8-9)$

imbricataria, Protocardia, II, 116, 117

inconspicuus, Pecten (Syncyclonema),

I, 317,320

inconstans, Neithea, I, 290

indicus, Eomiodon, II, 131

Indogrammatodon, I, 237

inequivalve, Entolium, I, 314

Inoperna, I, 258

insignis, Mesosaccella, I, 230, 27 (1)

insignis, Nuculana, I, 230

interstriatus, Pecten, I, 310

irregularis, Neithea, I, 289, 304

japetica, Arca, I, 240

japonica, Anthonya, II, 109, 112
G

$327,48(3-4)$

Goniomya, III, 163

Grammatodon, I, 237

grandicosta, Neithea, I, 284, 288

Gryphaea, I, 347

gryphaeata, Neithea, I, 290

Gryphaeostrea, I, 337, 347

guerangeri, Brachidontes, I, 259

guerangeri, Lecompteus cf., I, 259, 30

(11-12)

gurgitis, Anatina, III, 166

gurgitis, Cercomya, III, 166, 24 (8-10)

gurgitis, Lutraria, III, 153

gurgitis, Panopea, III, 153

$\mathbf{H}$

heiensis, Atrina, I, 283, 40 (7)

higoensis, Astarte, II, 84

higoensis, Malletia (Neilo?), I, 233, 27 (3-5)

higoensis, Pulsidis, III, 156

hiraigensis, Protocardia, II, 119, 15 (810)

Hoernesia, I, 263

hokkaidoensis, Glycymeris, I, 253

hokkaidoensis, Opis (Opis), II, 106

Hormomya, I, 260

hourcqi, Neithea, I, 291

humboldti, Amphidonta, I, 345

I

ishidoense, Amygdalum, I, 257, 30 (410)

ishidoense, Cardium, II, 123

ishidoense, Laevicardium (?), II, 123, 17 (8-10)

ishidoensis, Limatula, I, 332, 49 (5)

ishidoensis, Modiola (?), I, 257

ishidoensis, Nucula, I, 234

ishidoensis, Nuculopsis (Palaeonucula), I, 234

Isocyprina, II, 137

Isognomon, I, 278

Isognomon (Mytiloperna) sp., I, 280, $39(6-7)$

iwatensis, Bakevellia, I, 275, 35 (7-8)

Izumia, II, 146

japonica, Eriphyla, II, 104

japonica, Pholadomya, III 
japonica, Scittila, II, 126, 18 (1)

japonica, Veniella aff., II, 139, 19 (10)

japonicus, Pseudasaphis, II, 131

kagaharensis, Crassatella, II, 107

kagaharensis, Pachythaerus, II, 107, 13 (7-77), $14(14-15)$

kambarensis, Astarte, II, 93

kanmerai, Neithea (Neithea), 1, 290, $305,43(1-5), 52(3)$

kaufmanni, Neithea, I, 293

Keenaea, II, 122

keuperiana, Perna, I, 281

kiiensis, Plicatula, I, 323, 46 (6-8)

kiiensis, Ptychomya, II, 141

laevis, Neithea, I, 293

lapidis, Eriphyla, II, 97

lapparenti, Neithea, I, 290

Larma, II, 146

Laternula, III, 167

Lecompteus, I, 259

Legumen, II

Leionucula, I, 235

lenticularis, Eriphyla, II, 100

Limatula, I, 331

magna, Cyclina, II, 147

Malletia, I, 233

Malleus, I, 262

mariae, "Nuculana", I, 232

marrotiana, Glycymeris (Veletuceta),

I, 253

martini, Pholadomya, III, 159, 162

marullensis, Anatina, III, 168

marullensis, Barbatia, I, 249

marullensis, Glycymeris, I, 253, 255

matheroniana, Neithea, I, 291

matsumotoi, Costocyrena, II, 133, 18 $(2-12)$

matsumotoi, Neithea (Neithea), I, 288, 297,41 (1-7)

matsushimaensis, "Teredo", III, 172, 26 (6-9)

meekii, Dosiniopsis, II, 145

Melina, I, 280

meridiana, Eriphyla, II, 104

Mesocallista, II, 146

Mesocorbicula, II, 128

Mesosaccella, I, 230 japonicus, Spondylus, II, 326

johannisboehmi, Neithea, I, 291

K

kimurai, Variamussium, I, 320, 46 (14)

kitchini, Ptychomya, II, 143

koeneni, Ptychomya, II, 142

koikorobensis, Agapella (?), II, 144, 20 (14)

kotoi, Lucina, II, 113

kotoi, Lucinoma (?), II, 113, 15 (4-6)

kotsubu, "Neithea", I, 285

kurumense, Crenotrapezium, II, 128

L

lindiensis, Neithea, I, 290

lineata, Anthonya, II, 112

lineata, "Nuculana", I, 231

Liostrea, I, 336

lombardi, Lopha, I, 339

longicauda, Neithea, I, 291

Lopha, I, 338

Lucinoma, II, 113

Lucinoma (?) sp., II, 114

lunulatus, Eomiodon, II, 133

M

Mesosaccella sp., I, 233, 27 (2)

metaforbesiana, Gervillia, I, 276

meyeri, Plagiostoma, I, 329

Midiraon, II, 110, 140

minima, Eriphyla (Eriphyla), II, 99, $9(13-16), 14(12-13)$

minor, Astarte (Nicaniella), II, 91, 8 (19-22)

minos, Exogyra, I, 347

Miyakoella, II, 100

miyakoensis, Astarte, II, 101

miyakoensis, Astarte cf., II, 104

miyakoensis, Eriphyla (Miyakoella),

II, 101, 10 (1-8), 11 (1-8)

mipakoensis, Eriphyla (Miyakoella) cf., II, 104

miyakoensis, Gervillaria, I, 71, 36 (24), 37 (1)

miyakoensis, Gervillia, I, 271

miyakoensis, Pecten (Camptonectes) I, 318

miyakoensis, Pectinella, I, 318, 45 (211), 52 (5) 
miyamotoi, Pholadomya, III, 157, 22 (914), 23 (3-5)

modesta, Myoconcha, II, 76, 13 (1)

Modiolus, I, 255

Monia, I, 334

morii, Protocardia, II, 120

morrisi, Neithea, I, 288, 299, 300, 302

Mulletia, I, 262

Nagaoella, II, 145

nagaoi, Limatula, I, 333, 49 (8-11), 50 (1-2)

nagaoi, Pachythaerus, II, 108, 109

nagaoi, Panopea (Myopsis), III, 155, 22 (8)

nagaoi, Pleuromya, III, 155

nakanoi, Opis (Opis), II, 105, 11 (1112)

Nanonavis, I, 237

nasuta, Scittila, II, 126, 127

neckerianum, Cardium, II, 116

Neilo, I, 233

Neithea, I, 284

Neithea (Neithea) sp., I, 301, 43 (7)

Neithella, I, 291, 306

Neitheops, I, 284

Nemocardium, II, 120

neocomiensis, Neithea, I, 291

neocomiensis, Opis, II, 106

obliquata, Trigonarca cf., I, 248, 28 (17)

obliquata, Trigonoarca (?), I, 248

obovatus, Pecten (Syncyclonema), I, 317

obsoleta, Trigonarca, I, 247

obsoleta, Trigonoarca (?), I, 248

occidentalis, Neithea, I, 289, 304

Offadesma, III, 169

omalioides, Astarte, II, 89

Pachycardium, II, 125

Pachythaerus, II, 107

Palaeonucula, I, 234

Panis, I, 262

Panopea, III, 152

paradoxa, Cyrena, II, 131, 133, 135

Paraesa, II, 146

Parallelodon, I, 236

Parapecten, I, 285 munieri, Hoernesia, I, 264

Musculiopsis, II, 128

Myoconcha, II, 75

Myopsis, III, 153

Myrene, II, 128, 130

Mytiloperna, I, 280

Mytilus, I, 260

Mytilus (?) sp., I, 260, 30 (13)

$\mathbf{N}$

neocomiensis, Pholadomya, III, 154

neocomiensis, Ptychomya, II, 143

Neocrassina, II, 81

Neomiodon, II, 128

Netschajewia, II, 76

newcombii, Gervillia, I, 265, 268

Nicaniella, II, 90

nilsonni, Pecten, I, 320

nipponica, Grammatodon, I, 236

nipponica, Neithea (Neithea), I, 288, 296, 40 (1-6), 52 (1-2)

nipponicus, Parallelodon, I, 236, 27 (67)

nonvscripta, Goniomya, III, 165

Noramya, I, 244

notabilis, Neithea, I, 291

noutai, Neithea, I, 293

Nuculana, I, 235

Nuculopsis, I, 234

nummulare, Entolium, I, 314

$\mathrm{O}$

onoensis, Modiolus (Volsella), I, 258

Opis, II, 104

Opis (Opis) sp., II, 106

orbiculare, Entolium, I, 314, 316

ornithopus, Neithea, I, 292

oshimensis, Gryphaea, I, 348, 51 (3-7), 52 (9)

ovoides, Eriphyla, II, 97

ovula, Astarte, II, 84

ovula Pholadomya, III, 161

$\mathbf{P}$

parasitica, Exogyra, I, 345

parva, Cyclina, II, 147

pasiopae, Astarte, II, 100

passuana, Trigonarca, I, 248

Pectinella, I, 317

pectinoides, Neithea, I, 293

pedelnalis, Pholadomya, III, 161

Pentagrammysia, III, 163

Periploma, III, 170, 171 
Periplomya, III, 171

perplana, Scambula, II, 110

petersi, Pterinella, I, 261, 265, 268

phaseola, Neithea, I, 293

phaseolina, Neithea, I, 293

Pholadomya, III, 157

Pholadomya sp., III, 162, 24 (4-6)

Phylloda, II, 127

Pinna, I, 281

Pinna sp., I, 282, 39 (4)

Plagiostoma, I, 326, 327

playfordi, Eriphyla, II, 99, 103

Plectomya, III, 168

Plesiopinna, I, 283

plicata, Mya, III, 153

plicata, Panopea (Myopsis), III, 153, $22(1-7)$

Plicatula, I, 322

praemysis, Astarte (Nicaniella), II, 92

praetypica, Astarte (Freiastarte), II, 89

Pratulum, II, 122

Prohinnites, I, 313

prolata, Arca, I, 249

prolata, Eonavicula, I, 249

quadricostata, Neithea, I, 291, 306

quinquecostata, Neithea, I, 284, 288,

radiatostriata, Costocyrena, II, 135, 19 (1-7)

radiatostriata, Costocyrena aff., II, 137, $18(13-15)$

radiatostriata, Cyrena, II, 135

Radioconcha, II, 139

rapa, Ctenoides, I, 331

Rasatrix, II, 146

rataensis, Grammatodon, I, 237

rauliniana, Ostrea, I, 345

rauliniana, Perna, I, 279

raulinianum, Cardium, II, 122

rectior, Modiolus, I, 258

Remondia, II, 110

remondianum, Cardium, II, 125

requierriana, Glycymeris, I, 251

sachalinensis, Nanonavis, I, 240

sakamotoensis, Astarte, II, 96

sakawana, "Astarte", II, 130

samarangae, Nemocardium (Keenaea)
R

propebanneianum, Cardium (Tendagurium), II, 117

Protamussium, I, 314

Protocardia, II, 116

Protocardium, II, 116

Protocyprina, II, 128, 130

Pseudamiantis, II, 147

Pseudamussium, I, 318

Pseudaphrodina, II, 146

Pseudasaphis, II, 131

Pseudocardia, II, 77

Pseudoptera, I, 263

pseudoradiata, Anomia, I, 335

pseudorostrata, Bakevellia, I, 273, 37 (3-6)

pseudorostrata, Gervillia, I, 273

pseudotruncata, Anomia, I, 335, 336

pseudotruncata, Monia $c f .$, I, 335, 48 (1)

Pterinella, I, 261, 265

Pteroperna, I, 263

Ptychomya, II, 139

pulchella, Eriphyla (Eriphyla), II, 98, 9 (6-12), 14 (6)

Pulsidis, III, 156

Q

297

rigida, Syncyclonema, I, 314, 315

rikuzenica, Isognomon, I, 279

robinaldina, Anatina, III, 166, 167

robinaldina, Chlamys, I, 310, 44 (5-7)

robinaldina, Pinna of., I, 281, 39 (2-3)

robinaldina, Ptychomya, II, 140

robinaldina, Thracia, III, 171

robinaldinus, Pecten, I, 310

roemeri, Neithea, I, 294

roemeri, Spondylus, I, 325

rogeri, Pholadomya, III, 161

rostrata, Bakevellia, I, 274

rothpletzi, Protocardia, II, 116, 119

rotunda, Agapella, II, 145

rotundata, Cardita, II, 78

II, 122

sanchuense, Entolium, I, 315, $45(12-$ 13), $52(5)$

sanchuensis, Isognomon (Isognomon), 
I, 278

sanchuensis, Perna, I, 278

sanchuensis, Nuculana, I, 235

sanriquense, Plagiostoma (Acesta), I, $326,48(2)$

saxoneti, Crassatella, II, 108

Scambula, II, 110

Scittila, II, 126

Scittila sp., II, 127, 19 (11)

securis, Nanonavis, I, 240

sedgwicki, Isocyprina, II, 138

Seendia, II, 108

seikaianum, Tendagurium, II, 119

semicostata, Astarte (Astarte), II, 86, $8(3-10)$

semiplana, Lopha, I, 339

senecta, Astarte, II, 83

sexcostata, Neithea, I, 288, 299

shattucki, Pholadomya, III, 158

shawi, Neithea, I, 288, 301

shikokuensis, Chlamys (?), I, 312, 44 (8)

shinanoensis, Arca, I, 249

shinanoensis, Astarte (Yabea), II, 93, 8 (25-26), 14 (7-8)

shinanoensis, Astarte (Yabea) aff., II, $94,9(1), 14(9)$

shinanoensis, Bakevellia, I, 274

shinoharai, Pterinella, I, 265, 31 (1-3), $32(1-6), 33(1-2), 34(1-2), 85(1-2)$

simplex, Plagiostoma, I, 329

simplicius, Pecten, I, 319

sinuata, Astarte, II, 110

spatulata, Cercomya, III, 167

sphaeroidea, Protocardia (Globocardium)

II, 117, 16 (1-6)

sphaeroideum, Cardium, II, 116, 117

spillmani, Pachycardium, II, 125

spinosus, Spondylus, I, 326

Spondylus, I, 324

tanohatensis, Corimya (?) III, $26(4,5)$

Tendagurium, II, 117

Tenea, II, 146

tenuicosta, Cardita, II, 77

tenuicosta, Pseudocardia cf., II, 77, $\gamma$ (1-3)

Teredo, III, 172

texana, Exogyra, I, 347

texana, Neithea, I, 290, 304

Texigryphaea, I, 347

Thetironia, II, 147

Thracia, III, 170 stantoni, Ptychomya, II, 140

stefanoi, Neithea, I, 291, 306

stephensoni, Idonearca, I, 244

striata, Astarte, II, 97, 104

striatella, Cucullaea cf., I, 238

striatocostata, Neithea, I, 288

stuhlmanni, Eriphyla, II, 103

subacuta, Chlamys cf., I, 312, 45

subacutus, Pecten, I, 312

subaequilateralis, Limatula, I, 334

subalpina, Neithea, I, 289

subarchiaci, Goniomya, III, 163, 25 (113)

subcantiana, Anthonya, II, 110, 12 (111)

subcantiana, Anthonya aff., II, 113, 13

(6)

subdepressa, Astarte, II, 100

subdinnensis, Pholadomya, III, 158

subhaliotoidea, Amphidonta, I, 343, 50

(6-9), 51 (1-2)

subhaliotoidea, Exogyra, I, 343

subhillanum, "Cardium", II, 122

subomalioides, Astarte (Freiastarte),

II, 88, 12 (18)

subomalioides, Astarte (Freiastarte) cf., II, 90, $8(24)$

subpedelnalis, Pholadomya, III, 160, 23

(1)

subrapa, Ctenoides, I, 328, 330, 48 (5), $52(7)$

subrotunda, Dosiniopsis, II, 145

subsenecta, Astarte (Astarte), II, 81, $7(10-18), 14(1-5)$

subsenecta, Astarte (Astarte) cf., II, $84,11(9-10)$

subsenecta var. costata, Astarte, II, 85

subsimplex, Modiolus cf., I, 256, 30 (3)

Syncyclonema, I, 314, 317

syriaca, Neithea, I, 288, 301

$\mathrm{T}$

Thracia sp., III, 170, 26 (3)

Tikia, II, 146

tombeckiana, Limatula, I, 332, 334

tombeckiana, Limatula cf., I, 332, 52

(8)

transatlantica, Myoconcha, II, 77

transversa, Cucullaea, I, 245

tricostata, Neithea, I, 288, 290

Tridonta, II, 81

trigeriana, Pholadomya, III, 161

Trigonarca, I, 247

Trigonocallista, II, 146 
triplicatus, Neithea, I, 289

tuberculata, Pholadomya, III, 160, 24 (1-3)

Tucetilla, I, 251

ultima, Antiquilima, I, 329, 49 (6) umbonata, Eriphyla, II, 96, 100 Undulomya, III, 163

valanginiensis, Neithea, I, 291

valdensis, Lucina, II, 114

Variamussium, I, 320

vectensis, Lima, I, 327

vectensis, Venus, II, 149

Vectorbis, II, 146, 149

Veletuceta, I, 251

Veniella, II, 139

walkeri, Exogyra, I, 345

weissermeli, Astarte, II, 101, 103

welwitschi, Neithea, I, 294, 309

Yabea, II, 92

yabei, Amphidonta (CeratostreonQ, I, $345,49(12), 50(3-5)$

yabei, Exogyra, I, 338, 339, 345

yatsushiroense, Entolium (?), I, 316, 48 (6)

yatsushiroense, Nemocardium, II, 120,
Tucetona, I, 251

Tucetonella, I, 251

Tutcheria, II, 77
$\mathbf{U}$

upwarensis, Eriphyla, II, 101, 103 utakokense, Entolium, I, 316

V

versicostata, Neithea, I, 285, 289

vesicularis, Gryphaeostrea sp. ex gr., I, 337,51 (8)

vesicularis, Ostrea, I, 337

Volsella, I, 255

voltzi, Cardium, II, 122

vulgaris, Eomiodon, II, 133

W

Weyla, I, 285

woodsi, Anthonya, II, 109

wrightii, Neithea, I, 291, 292, 308

Y

$17(1-7)$

yokoyamai, Grammatodon, I, 238

yokoyamai, Nanonavis (Nanonavis), I, 238, 27 (8-13)

yokoyamai, Nanonavis (Nanonavis) cf., I, 241, 27 (14)

\section{Postscript I}

After a part of the manuscript of this serial study was completed, NEwELL (1965) presented a new scheme of pelecypod classification designed for the forthcoming "Treatise on Invertebrate Paleontology, Part N". His grouping and taxobasis are essentially similar to those of CoX (1960), which I adopted in the present descriptions, but quite different in the name of subclasses, orders and suborders. I have felt that the ordinal names hitherto proposed by many authors including Cox are somewhat troublesome and sometimes confusable, because they were derived from various taxonomic characters such as gill structures, hinge types, ligament characters, musculature and other morphological features. In this respect, the ordinal names, which are based on the names of typical representative genera and were adopted by NEwELL, would be accepted not only by palaeontologists but also by neontologists. Because the International Code 
of Zoological Nomenclature is concerned only with the names of the family-, genus- and species-groups, the adoption of ordinal and subordinal names may not necessarily adhere to the principle of priority.

Hereafter, I intend to change the ordinal and subordinal names, which were cited in the present study, as follows:

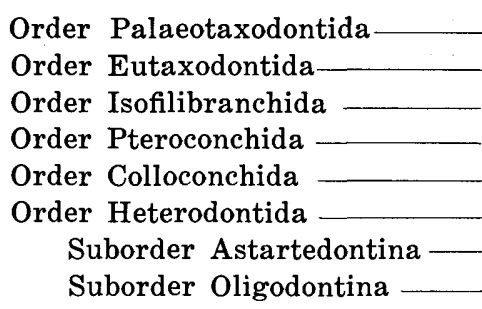

Order Nuculida

Order Arcida

Order Mytilida

$\left.\begin{array}{ll}\text { Suborder Pteriina } \\ \text { Suborder } & \text { Ostreina }\end{array}\right\}$ Order Pteriida

Order Venerida

Suborder Astartina

Suborder Venerina $[=$ Arcticina in NEWELL]

\section{Postscript II}

In the present study, the Kochian, Aritan and Miyakoan series, which appear to represent three major sedimentary cycles of the Lower Cretaceous in Japan, were conventionally assigned to Lower Neocomian, Upper Neocomian and AptianAlbian-Lowest Cenomanian respectively, as had been treated by many stratigraphers. It is, however, probable that the Aritan formations of the Outer Zone of Southwest Japan are partly correlated to the Lower Aptian, judging from some undescribed ammonites recently collected from the Katsuura area. There is much room for further investigation and improvement as to the correlation and chronology of the Japanese Lower Cretaceous. Dr. I. OBata of the National Science Museum and Mr. I. NAKAI of the Kyushu University are now carrying out the biostratigraphy and ammonite palaeontology concerning to the Aritan and Miyakoan series. Taking their results into consideration in future, I might be able to determine the range of each pelecypod species on a more reliable basis, and to discuss the transition of pelecypod faunas of this period, which was only provisionally summarized in a separate paper (HAYAMI, 1965).

\section{Postscript III (Nomenclatural correction)}

Read Amphidonte for Amphidonta in the 1st part of this study (pp.224, 343-347, pls. 49-51). The latter is an invalid emendation of the former and should be rejected, as pointed out by STENZEL (1947).

\section{Postscript IV}

After the manuscript of this serial study was completed, a full description of the molluscan fauna from the folded complex near the Omine mine, northwest of Kamaishi, Iwate Prefecture was published (NAKAZAwa and MURATA, 1966). The fauna includes the following pelecypods: Modiolus sp., Bakevellia (Neobakevellia) ominensis NAKAZAWA and MURATA, $B$. ( $N$ ?) tadai NAKAZAWA and MURATA, Cuneigervillia quadrata NAKAZAWA and MURATA, Waagenoperna elon- 
gata NAKAZAWA and MUrata, Isognomon sp., Pseudoptera n. sp. aff. P. viana StePhenson, Liostrea sp., Lopha sp., Protocardia ibukii Nakazawa and Murata, "Eomiodon" ominensis NAKAZAWA and Murata, Filosina sp. aff. F. jusanhamensis HAYAmi, Venilicardia? sp., Pleuromya sp.

They are mostly brackish-water species. Only Venilicardia? sp., which occurs together with Nerinea sp., is considered to be a marine inhabitant. The age is, as noted by the authors, probably Neocomian, but it is rather curious that the assemblage is quite distinct from that of the Kochian and Aritan pelecypod faunas of other areas. As suggested by the authors, "Eomiodon" ominensis belongs to Costocyrena HAYAMI, 1965, and may be specifically distinct from Costocyrena radiatostriata and $C$. matsumotoi.

\section{Postscript V}

After the 1st part of this study was published, Dr. Vladimir L. SHopov and Dr. Ekim BoNCEV of Bulgaria kindly gave me instructive information about the genus Pterinella, enclosing some copies of their papers and English translation of some other Bulgarian publications on the Lower Cretaceous mollusks of Balkan, which I had overlooked. According to PETKovic (1923) and some others, the fossil bed of Pterinella petersi, which Toula assigned originally to the Neocomian, is now considered to be Aptian. BoNCEv (1938) discussed the systematic position of the genus Pterinella and came to the conclusion that the genus was more closely related to the Pernidae [Isognomonidae plus Bakevelliidae in the present usage] than to the Aviculidae [=Pteriidae $s . l$.$] especially in the$ adult stage. Although the presence of anterior supplementary ligament pits is not as yet ascertained in Pterinella petersi, i.e. the type-species of the genus, it is clear that Pterinella shinoharai HAYAMI from Japan is closely related to P. petersi in view of all the other essential characters. Although the palaeontological data are still insufficient to determine the systematic position of this peculiar pelecypod genus, I maintain the aforementioned thought of phylogeny that Pterinella was not directly related to the Bakevelliidae or other multivincular pterioids but was probably derived from Pteroperna or its allied genera of the Pteriidae.

\section{References (addenda)}

Boncev, Ekim (1938): Über Pterinella und deren Stellung in der Systematik der Anisomyaria. Zentralb. f. Min. usw., 1938, (B), 264-269.

HAYAMI, Itaru (1965): Transition of Jurassic and Cretaceous marine pelecypods. Fossils, (9), 13-23 (in Japanese).

MAEDA, Shiro (1965) : Lower Cretaceous trigoniids from the Todai formation, central Japan. Jour. Coll. Arts and Sci., Chiba Univ., 4, (2), 47-57, pls. 1-4.

Nakazawa, Keiji (1965): On the Mesozoic fossils from the Omine mine, Iwate Prefecture (abstract). Jour. Geol. Soc. Japan, 71, (838), 386 (in Japanese).

- and Masafumi Murata (1966): On the Lower Cretaceous fossils found near the Ominé mine, Iwaté Prefecture, Northeast Japan. Mem. Coll. Sci., Univ. Kyoto, [B], 32, (4), 303-333 (pls. 3-6 incl.)

Newell, Norman D. (1965): Classification of the Bivalvia. American Museum, Novitates, (2206), 1-25.

Petkovic, V. K. (1923): L'étage aptien dans la Serbie orientale. Ann. Géol. Penins. Balkanique, $8,(2), 57-79$.

STENZEL, H. B. (1947): Nomenclatural synopsis of supraspecific groups of the family Ostreidae (Pelecypoda, Mollusca). Jour. Paleontology, 21, (2), 165-185. 
Itaru HAYAMI

Lower Cretaceous Marine Pelecypods of Japan

Part III

Plates $22 \sim 26$ 
Plate 22 


\section{Explanation of Plate 22}

Figs. 1-7. Panopea (Myopsis) plicata (Sowerby) ............. Page 153

1. Left valve (GK. H6536) $\times 1$. Loc. Hiraiga formation at $\mathrm{Hn} .0017$, south of Hiraiga, Tanohata village, Iwate Pref. (HANAI and HaYami coll.)

2. Right internal mould (GK. H6537) $\times 1$. Loc. Hiraiga formation (boulder) at the south of Hiraiga, the same village. (HAYAMI coll.)

3. Right valve (GK. H6712) $\times 1$. Loc. Hiraiga formation at Hn. 0017, south of Hiraiga, the same village (HANAI and HAYAMI coll.)

4. Left valve (GK. H6535). Loc. ditto. (HANAI and HAYAMI coll.) 4a: lateral view $(\times 1) ; 4 \mathrm{~b}$ : ornamentation on the central part of the same specimen $(\times 4)$.

5. Left valve (GK. H6539) $\times 1$. Loc. ditto. (HAYAmi coll.)

6. Right valve (GK. H6711) $\times 1$. Loc. ditto. (HANaI and HaYami coll.)

7. Left valve (GK. H6538) $\times 1$. Loc. ditto. (HANAI and HaYami coll.)

Fig. 8. Panopea (Myopsis) nagaoi sp. nov. ........................ 155

8. Right internal mould (GK. H6545) $\times 1.5$. Holotype. Loc. Yatsushiro formation at $\mathrm{Km} .3096$, southwest of Kohara, Toyo village, Kumamoto Pref. (KANMERA coll.)

Figs. 9-14. Pholadomya miyamotoi NAGAo ...................... 157

9. Left valve (GK. H6550) $\times 2$. Loc. Hiraiga formation at Hn. 0018, south of Hiraiga, Tanohata village, Iwate Pref. (HANAI and (HAYAMI coll.)

10. Right valve (GK. H6547) $\times 2$. Loc. ditto. (HAYAMI coll.)

11. Right valve (GK. H6551) $\times 2$. Loc. ditto. (HAYAMI coll.)

12. Right valve (GK. H6548) $\times 2$. Loc. ditto. (HANAI and HaYami coll.)

13. Right valve (GK. H6802) $\times 2$. Loc. Hiraiga formation (boulder) at the south of Hiraiga, the same village. (HAYAMI coll.)

14. Right valve $($ GK. H6553) $\times 2$. Loc. Hiraiga formation at $\mathrm{Hn} .0017$, south of Hiraiga, the same village. (HANAI and (HAYAMI coll.)

All specimens illustrated are kept in the Department of Geology, Kyushu University. 

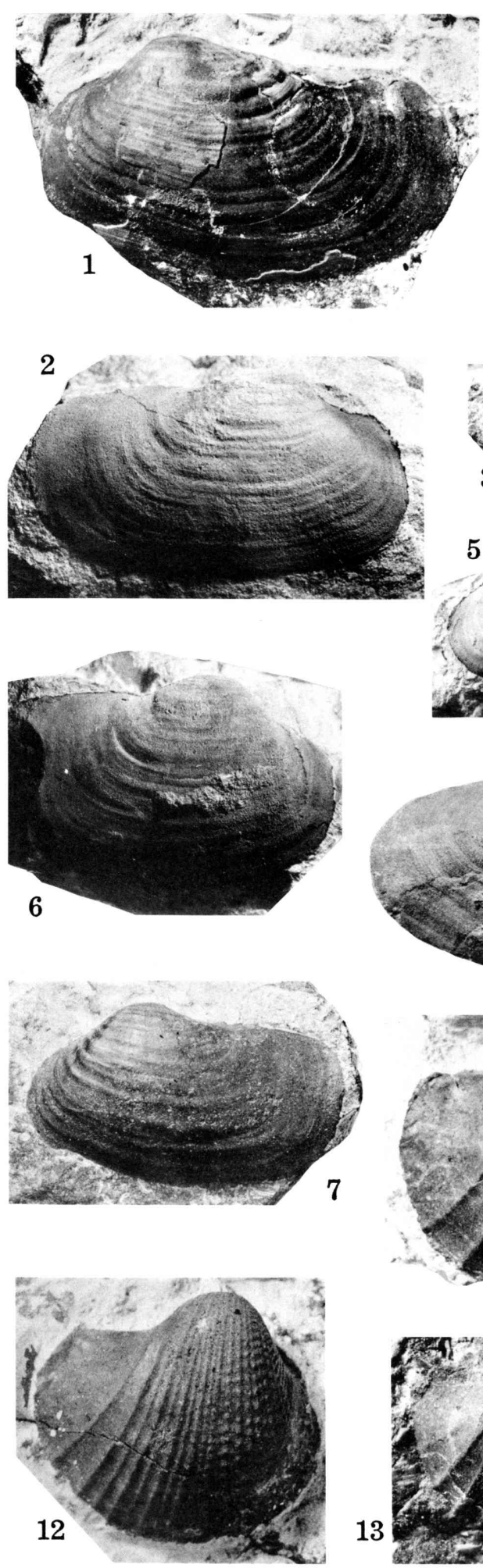
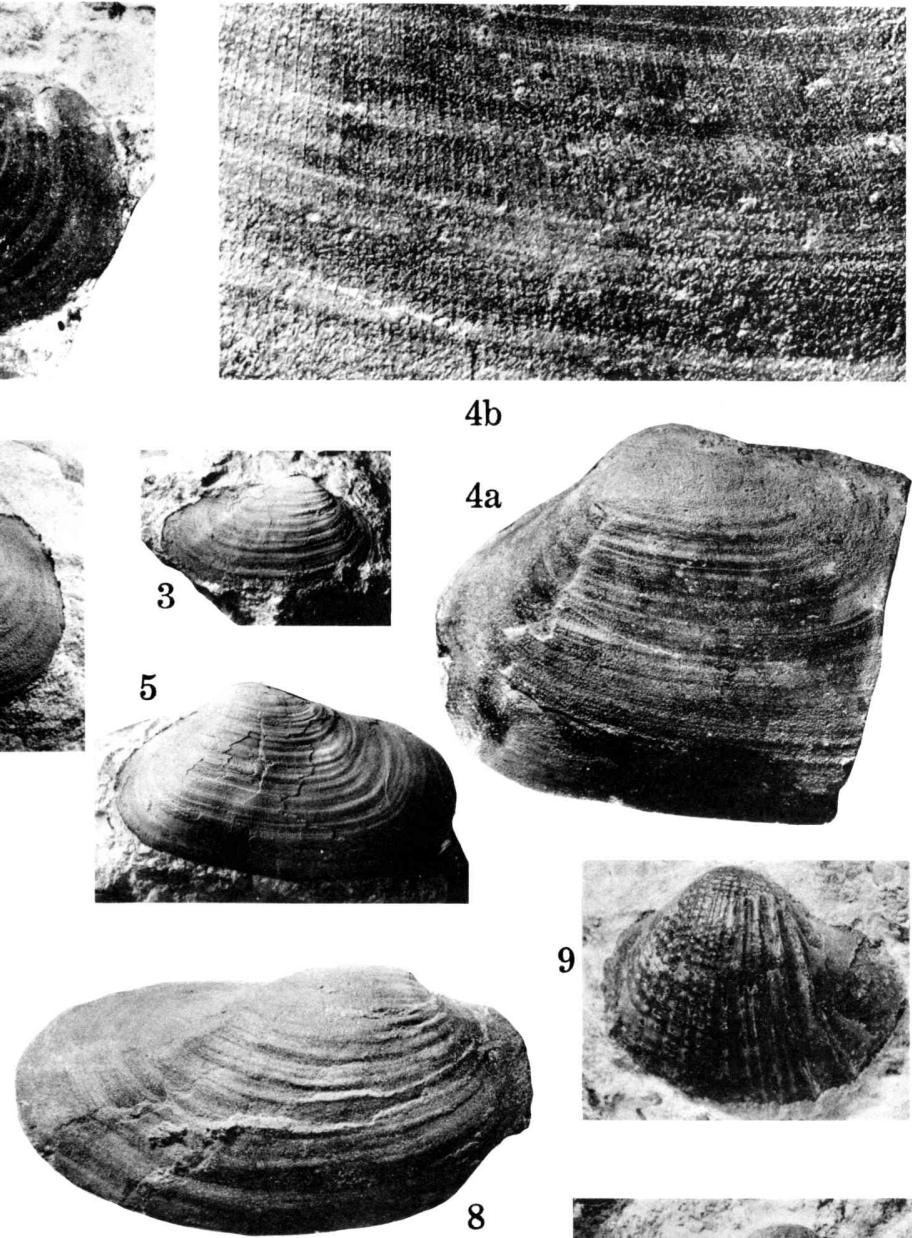

$4 \mathrm{~b}$
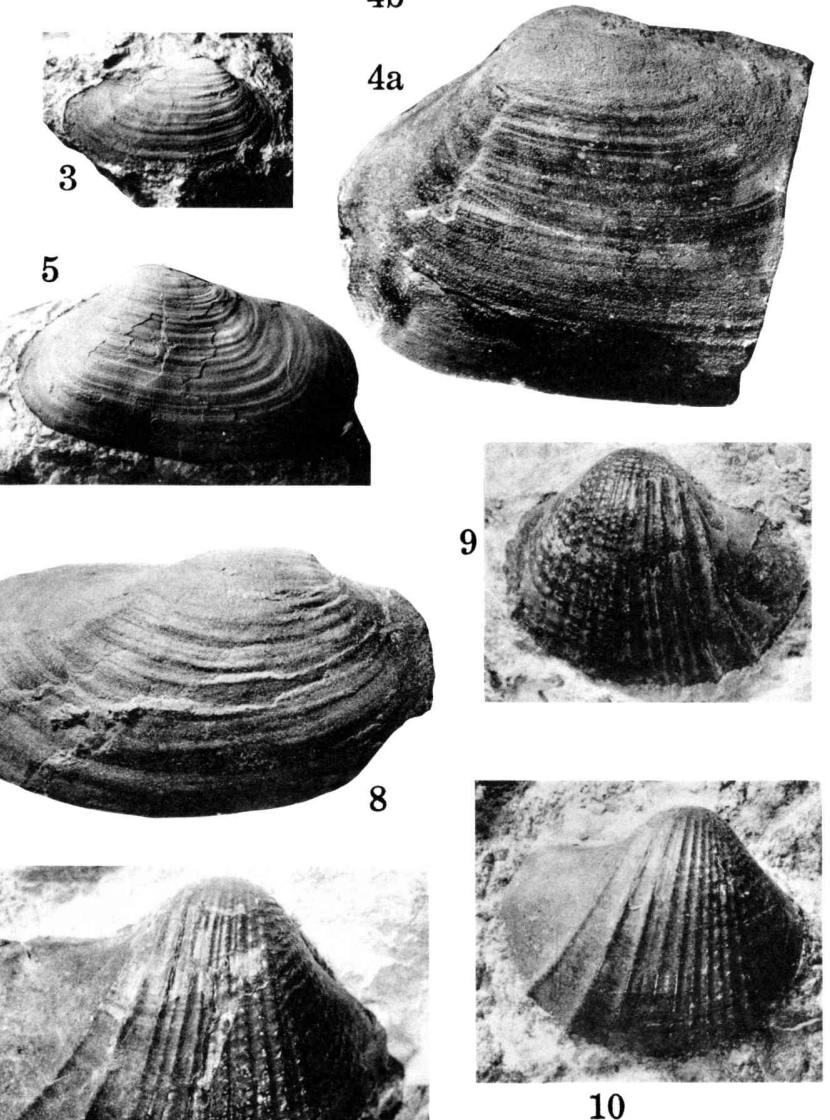

11
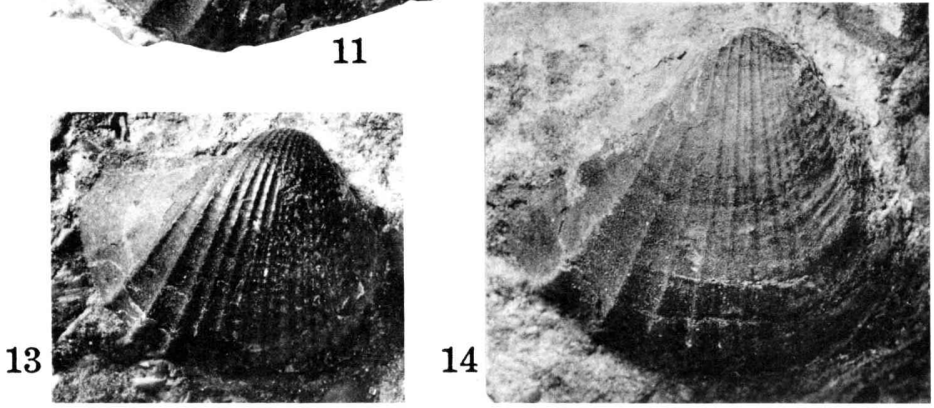
Plate 23 


\section{Explanation of Plate 23}

Fig. 1. Pholadomya subpedelnalis Nagao ........................... 160

1. Internal mould of closed valves $(\mathrm{GK} . \mathrm{H} 6558) \times 2$. Loc. "Orbitolina sandstone" of the Miyako group at Hn. 6203, northeast of Raga, Tanohata village, Iwate Pref. (HAYAmi coll.) 1a: left valve; $1 \mathrm{~b}$ : right valve.

Fig. 2. Pholadomya brevitesta NAGAO ............................ 158

2. Both valves (GK. H6554) $\times 1$. Loc. Tanohata formation at Hn. 0006, south of Hiraiga, the same village. (HANAI coll.) 2a: left valve; $2 \mathrm{~b}$ : right valve; $2 c$ : upper view.

Figs. 3, 4. Pholadomya miyamotoi Nagao ....................... 157

3. Rubber cast from a right external mould (GK. H6801) $\times 2$. Loc. Hiraiga formation (boulder) at the south of Hiraiga, the same village. (HANAI coll.)

4. Right internal mould (GK. H6549) $\times 1.5$. Loc. ditto. (HANAI and HAYAMI coll.)

Fig. 5. Part of a slab with Pholadomya miyamotoi NAGAo (5a), Panopea (Myopsis) plicata (SowerBY) (5b) and Goniomya subarchiaci NAGAO (5c, 5d) $\times 1$.

5a. Right valve $($ GK. H6802) $\times 1$. Loc. Hiraiga formation (boulder) at the south of Hiraiga, the same village (HAYAMI coll.)

All specimens illustrated are kept in the Department of Geology, Kyushu University. 


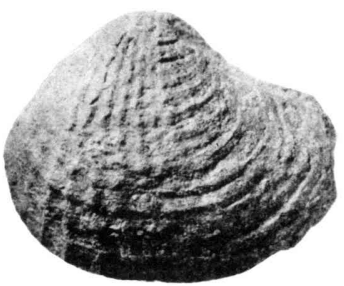

1a

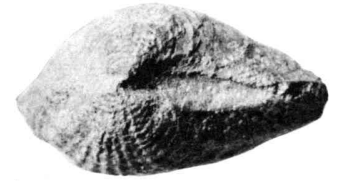

$1 \mathrm{c}$

3

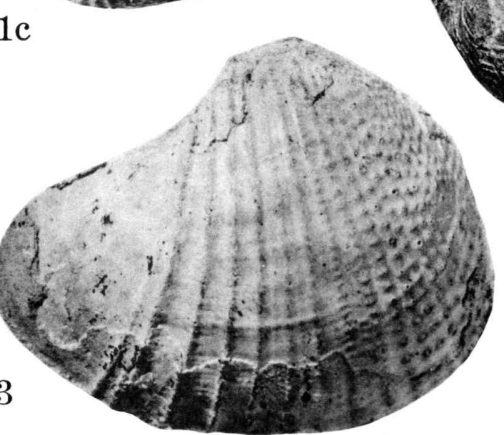

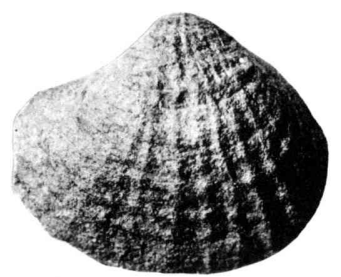

$1 b$

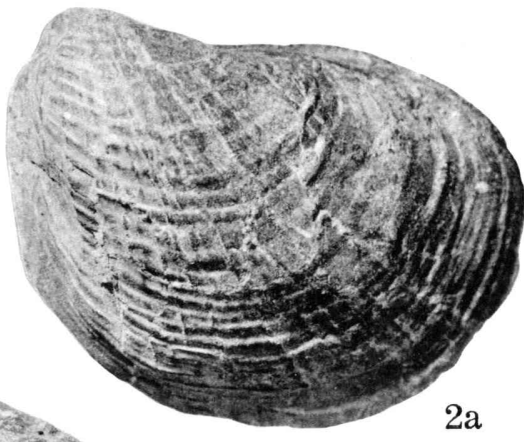

$2 \mathrm{a}$
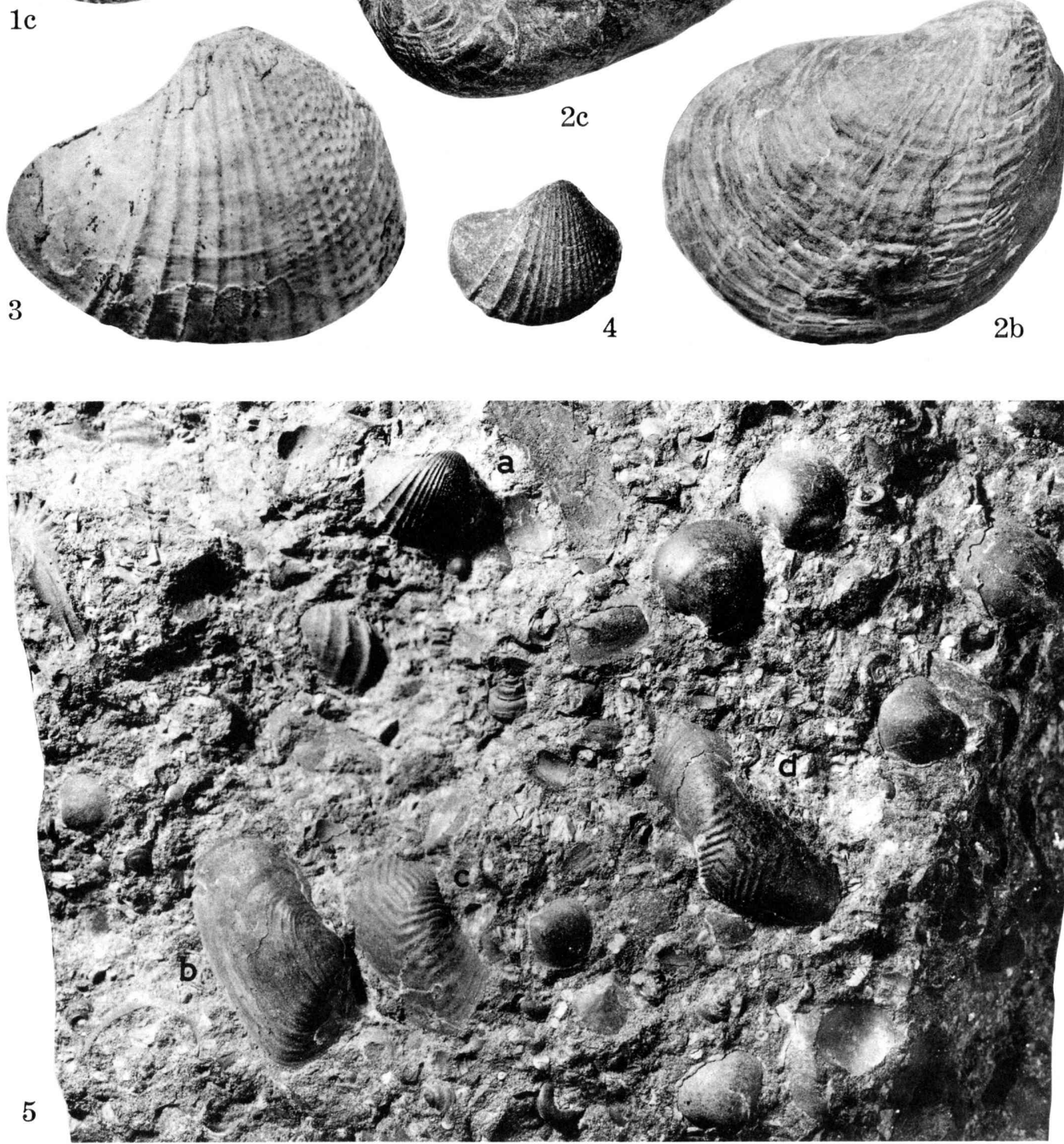

I. Hayami : Lower Cretaceous marine Pelecypods of Japan 
Plate 24 


\section{Explanation of Plate 24}

Figs. 1-3. Pholadomya tuberculata sp. nov. ..................... 160

1. Left valve (GK. H6556) $\times 2$. Paratype. Loc. Hiraiga formation at Hn. 0018, south of Hiraiga, Tanohata village, Iwate Pref. (HANaI and HAYAMI coll.)

2. Left valve (GK. H6577) $\times 2$. Paratype. Loc. Hiraiga formation at $\mathrm{Hn}$. 0017, south of Hiraiga, the same village. (HANAI and HaYAMI coll.)

3. Left valve (GK. H6555) $\times 2$. Holotype. Loc. Hiraiga formation at $\mathrm{Hn}$. 0018, south of Hiraiga, the same village. (HANAI and HAYAMI coll.)

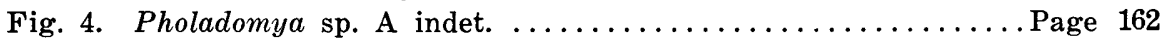

4. Left internal mould (GK. H6781) $\times 1$. Loc. Hagino formation at Hy. 6011, Hagino, Mirafu village, Kochi Pref. (OGaWa coll.)

Figs. 5, 6. Pholadomya sp. B indet. .................... Page 162

5. Internal mould of closed valves $($ GK. H6791) $\times 1.5$. Loc. Hanoura formation (boulder) at Hiroyasu, Katsuura town, Tokushima Pref. (HAYami coll.) $5 \mathrm{a}$ : right valve; $5 \mathrm{~b}$ : left valve.

6. Left internal mould (GK. H6792) $\times 1.5$. Loc. Yatsushiro formation at $\mathrm{Km} .1843$, north of Shimofukami, Sakamoto town, Kumamoto Pref. (KANMERA coll.)

Fig. 7. Goniomya sp. indet. ............................ 165

7. Left internal mould (GK. H6573) $\times 1.5$. Loc. Ishido formation at Hy. 4001, Ichinose-bashi, Nakazato village, Gunma Pref. (IchIKaWA and HAYAMI coll.)

Figs. 8-10. Cercomya gurgitis (Pictet and CAMPICHE) ...........Page 166

8. Right internal mould (GK. H6575) $\times 1.2$. Loc. Hiraiga formation at Hn. 0018, south of Hiraiga, Tanohata village, Iwate Pref. (HANAI and HAYAMI coll.)

9. Left valve (GK. H6574) $\times$ 1.5. Loc. ditto. (Hayami coll.)

10. Internal and external moulds of closed valves $($ GK. H6576) $\times 1$. Loc. "Orbitolina sandstone" of the Miyako group at $\mathrm{Hn} .6202$, northeast of Raga, the same village. (HANAI and HAYAMI coll.) 10a: left internal mould; 10b: right internal mould; 10c: left external mould; 10d: its rubber cast.

All specimens illustrated are kept in the Department of Geology, Kyushu University. 

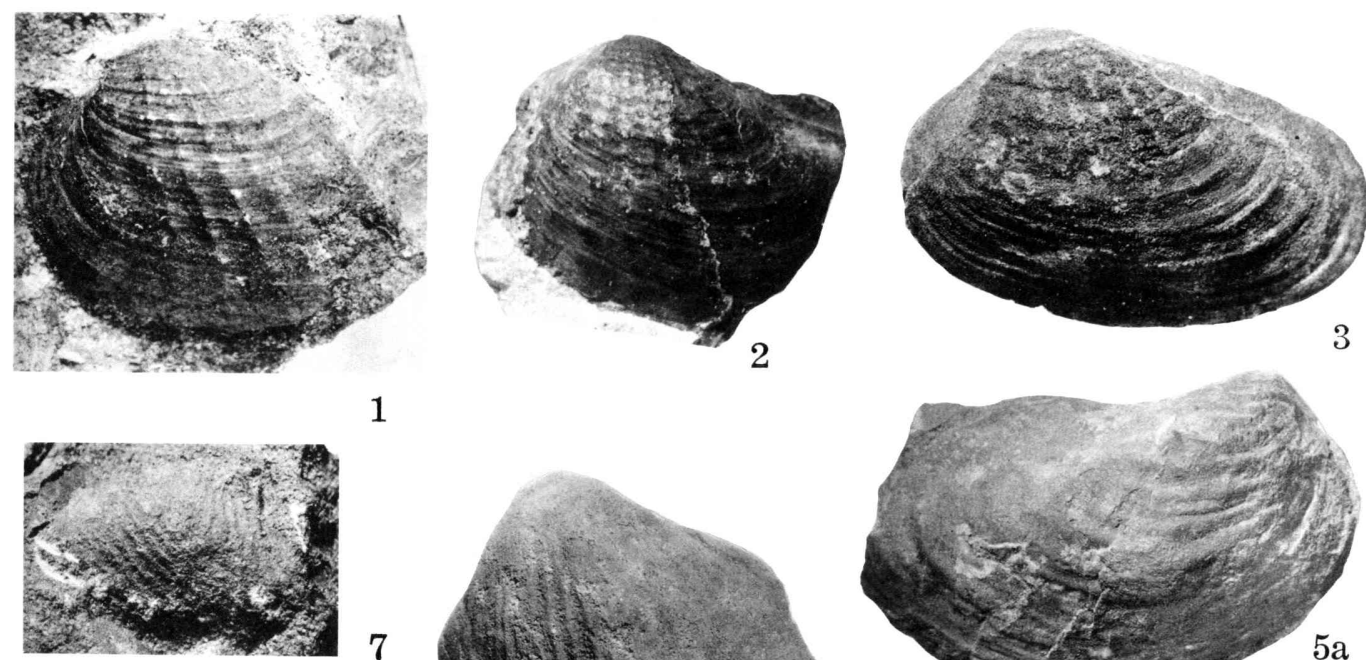

1
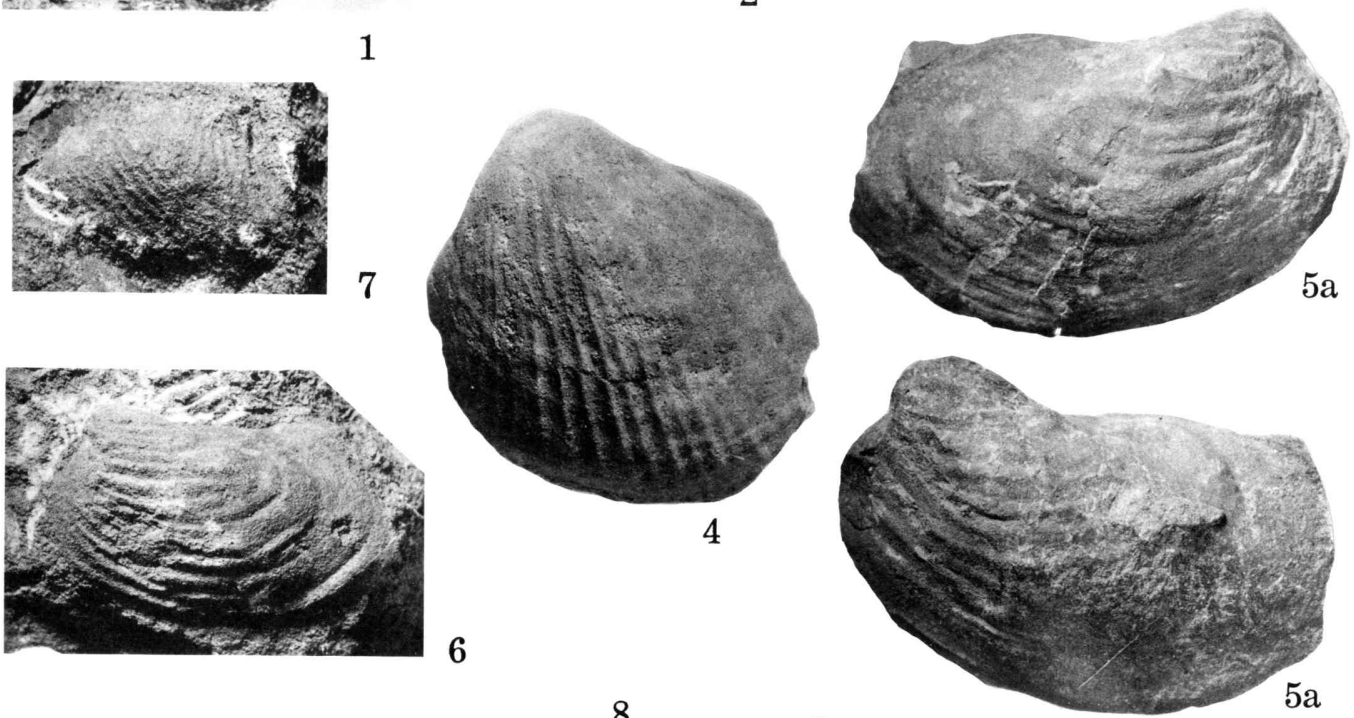

8

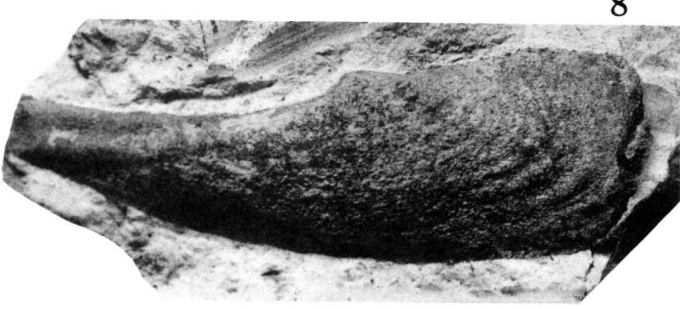

9
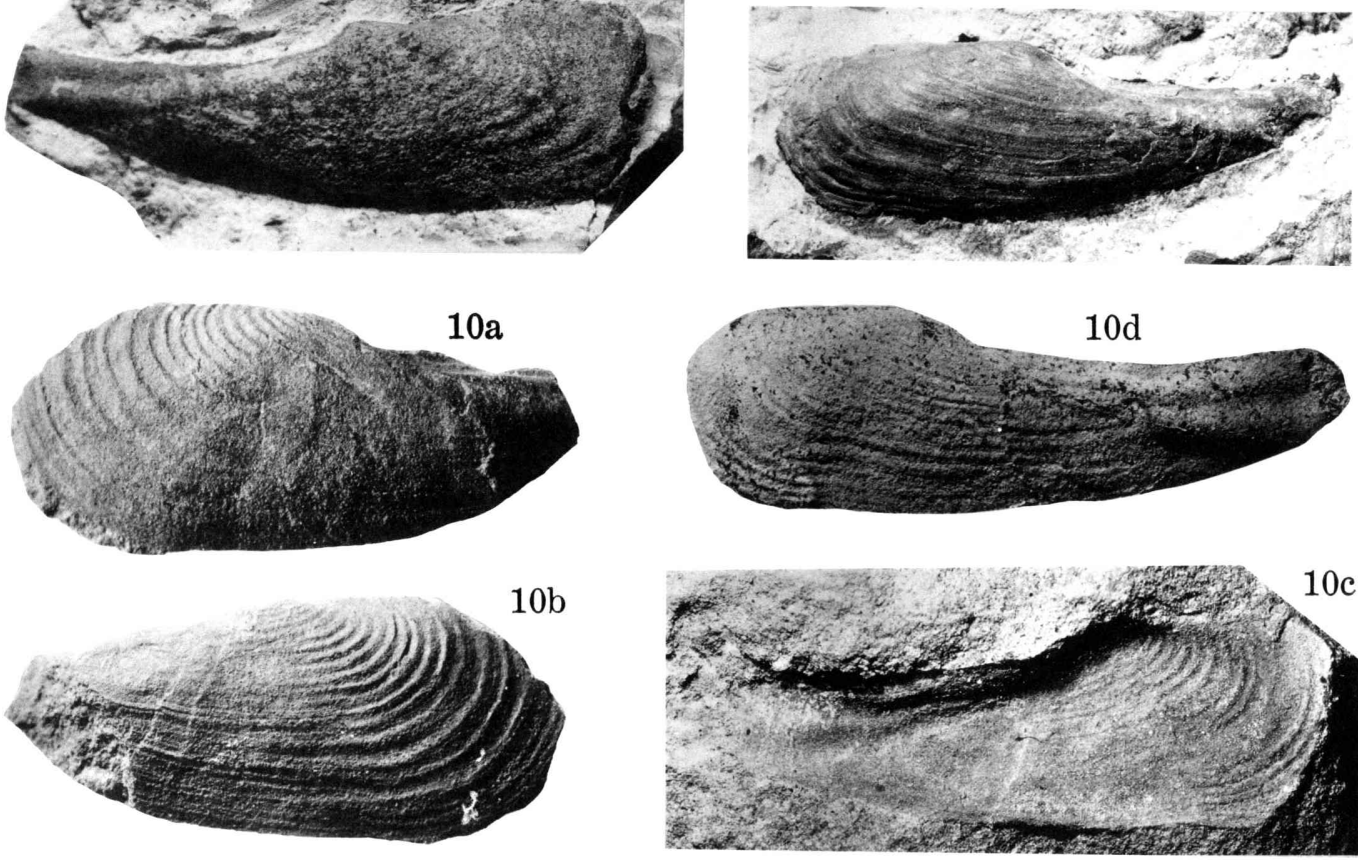

I. HAYAMI: Lower Cretaceous marine Pelecypods of Japan 
Plate 25 


\section{Explanation of Plate 25}

Figs. 1-13. Goniomya subarchiaci NAGAO ........................ 163

1. Left valve (GK. H6561) $\times 1.5$. Loc. Hiraiga formation at Hn. 0017, south of Hiraiga, Tanohata village, Iwate Pref. (HANAI and Hayami coll.)

2. Left valve (GK. H6716). Loc. ditto. (HAYAMI coll.) 2a: lateral view $(\times 1.5) ; 2 b$ : ornamentation on the anterior part $(\times 5)$.

3. Left valve (GK. H6565) $\times 1.5$. Loc. ditto. (HAYAMI coll.)

4. Right valve (GK. H6564) $\times 1.5$. Loc. ditto. (HAYAMI coll.)

5. Left valve (GK. H6720) $\times 1.5$. Loc. ditto. (HAYAMI coll.)

6. Left valve (GK. H6717) $\times 1.5$. Loc. ditto. (HANAI and Hayami coll.)

7. Right valve (GK. H6562) $\times 1.5$. Loc. ditto. (HANAI and HaYAMI coll.)

8. Left valve (GK. H6559) $\times 1.5$. Loc. ditto. (HAYAMI coll.) 8a: lateral view; $8 \mathrm{~b}$ : upper oblique view.

9. Left valve (GK. H6563) $\times 1.5$. Loc. ditto. (HanaI and HaYami coll.)

10. Left valve (GK. H6560) $\times 1.5$. Loc. ditto. (HaYAMI coll.)

11. Right valve (GK. H6718) $\times 1.5$. Loc. ditto. (HANAI and HaYAMI coll.)

12. Left valve (GK. H6566) $\times 1.5$. Loc. Hiraiga formation at $\mathrm{Hn} .0016$, south of Hiraiga, the same village (HANAI and HAYAMI coll.)

13. Right valve (GK. H6802) $\times 1.5$. Loc. Hiraiga formation at Hn. 0018, south of Hiraiga, the same village. (HANAI coll.)

Figs. 14, 15. Plectomya aritagawana sp. nov. ..................... 168

14. Internal mould of closed valves (GK. H6577) $\times 2$. Holotype. Loc. Arita formation at Ys. 53, between Yuasa and Yoshikawa, Yuasa town, Wakayama Pref. (Матsuмото coll.) 14a: left valve; 14b: right valve.

15. Left internal mould (GK. H6578) $\times 1.5$. Paratype. Loc. Arita formation at Ys. 103, west of Kumai, the same town. (Matsumoto coll.)

Fig. 16. Plectomya sp. aff. P. anglica Woons ......................... 169

16. Internal mould of closed valves $(\mathrm{GK} . \mathrm{H} 6600) \times 1.5$. Loc. Yatsushiro formation at Hy. 1016, south of Miyaji, Yatsushiro City. (HAYAMI coll.) $16 \mathrm{a}$ : left valve; $16 \mathrm{~b}$ : right valve.

All specimens illustrated are kept in the Department of Geology, Kyushu University. 


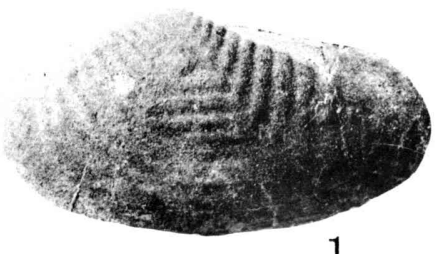

1
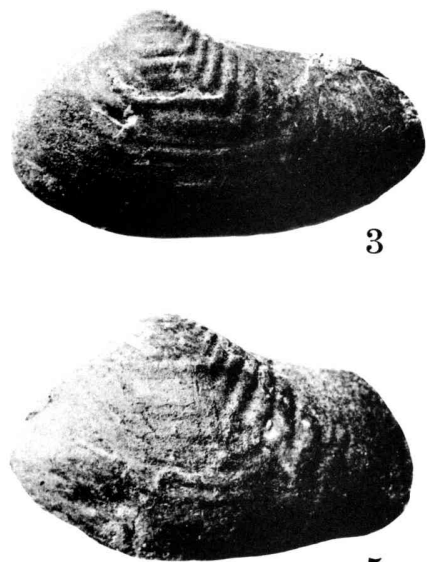

5
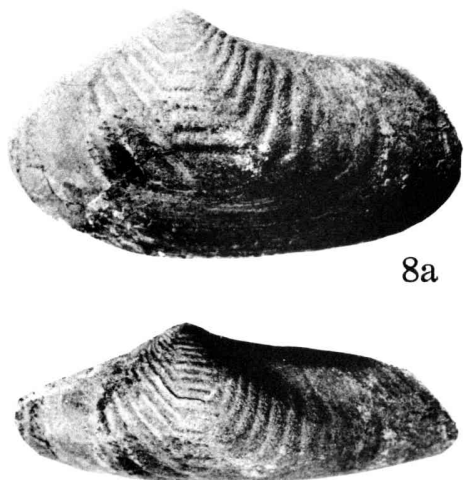

$8 \mathrm{~b}$
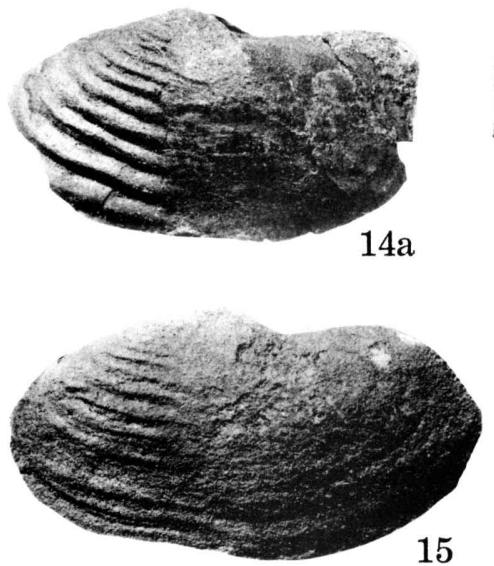

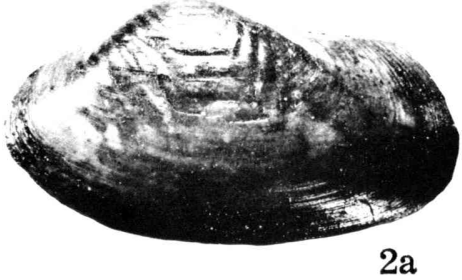

$2 \mathrm{a}$

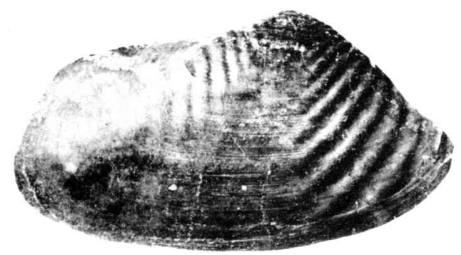

4
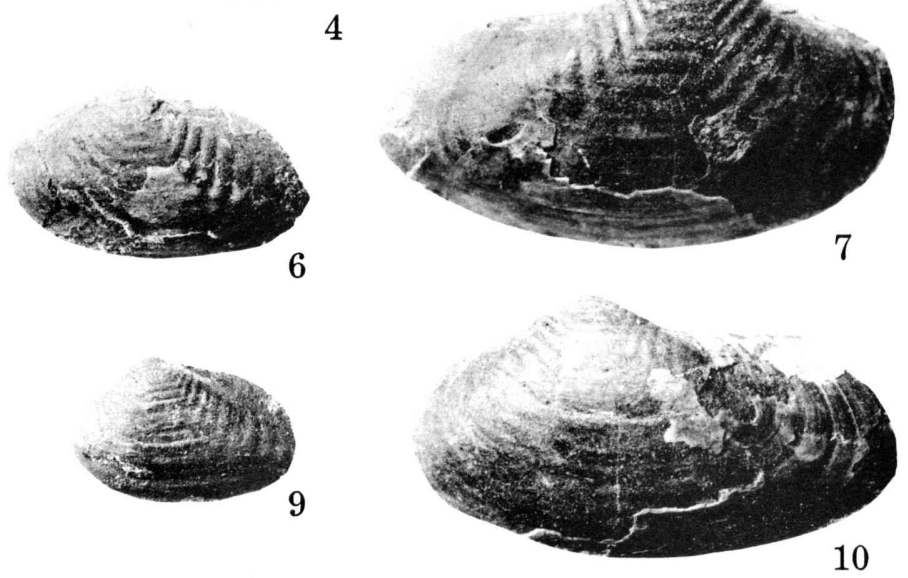

10

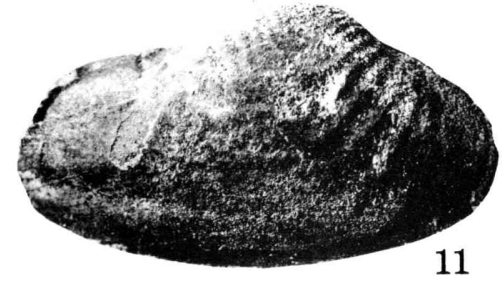

12
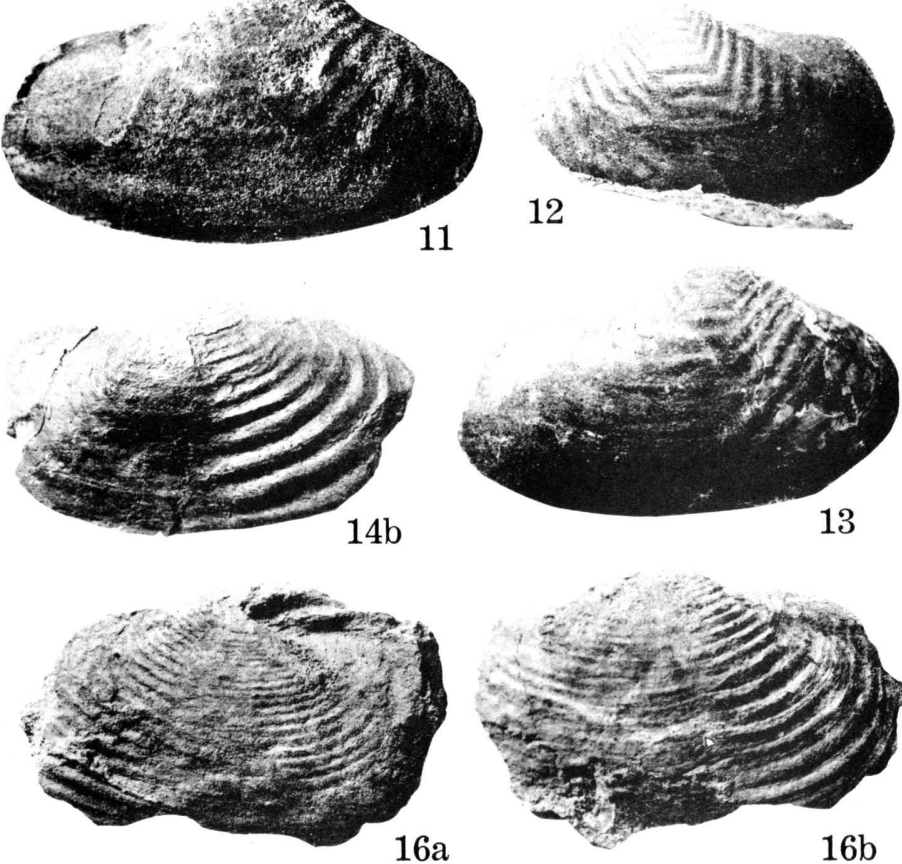

I. HAyAmi: Lower Cretaceous marine Pelecypods of Japan 
Plate 26 


\section{Explanation of Plate 26}

Fig. 1. Offadesma altissimum sp. nov. ................... Page 169

1. Internal mould of closed valves (GK. H6581) $\times 1.5$. Holotype. Loc. "Orbitolina sandstone" of the Miyako group at Hn. 6203, northeast of Raga, Tanohata village, Iwate Pref. (HANaI and HaYami coll.) 1a: left internal mould; 1b: right internal mould.

Fig. 2. Plectomya aritagawana sp. nov. ........................ 168

2. Right internal mould (GK. H6579) $\times 1.5$. Paratype. Loc. Yatsushiro formation at $\mathrm{Km} .3113$, Miyaji, Yatsushiro City. (KANMERA coll.)

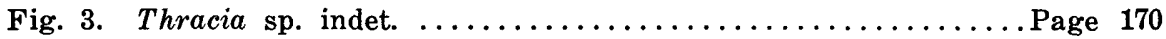

3. Left valve (GK. H6583) $\times 1.5$. Loc. Hiraiga formation at $\mathrm{Hn}$. 0017, south of Hiraiga, Tanohata village, Iwate Pref. (HAYami coll.)

Figs. 4, 5. Corimya (?) tanohatensis sp. nov. ............... Page 171

4. Internal and external moulds of closed valves (GK. H6724) $\times 1.5$. Holotype. Loc. Tanohata formation (boulder) at the south of Hiraiga, the same village. (HANAI and HAYAMI coll.) 4a: left internal mould; $4 \mathrm{~b}$ : right internal mould.

5. left internal mould (GK. H6725) $\times 1.5$. Loc. ditto. (HANAI and HaYami coll.)

Figs. 6-9. "Teredo" matsushimaensis HATAI ................ Page 172

6. Part of a slab (drift wood) with many calcareous tubes (GK. H6803) $\times 1$. Loc. 2nd cycle sediments of the Miyako group at Hn. 4154, Matsushima, Moshi, Iwaizumi town, Iwate Pref. (HanaI coll.)

7. Tube taken from a drift wood (GK. H6804) $\times 1$. Loc. ditto. (HaNAI coll.)

8. Tube taken from a drift wood (GK. H6776) $\times 1.5$. Loc. Hiraiga formation at Hn. 0017, south of Hiraiga, Tanohata village, Iwate Pref. (HAYAMI coll.)

9. Fragmentary right valve taken from the terminal part of a tube (GK. H6777) $\times 3$. Loc. 2nd cycle sediments of the Miyako group at Hn. 4154, Matsushima, Moshi, Iwaizumi town, Iwate Pref. (Hanai coll.)

All specimens illustrated are kept in the Department of Geology, Kyushu University. 

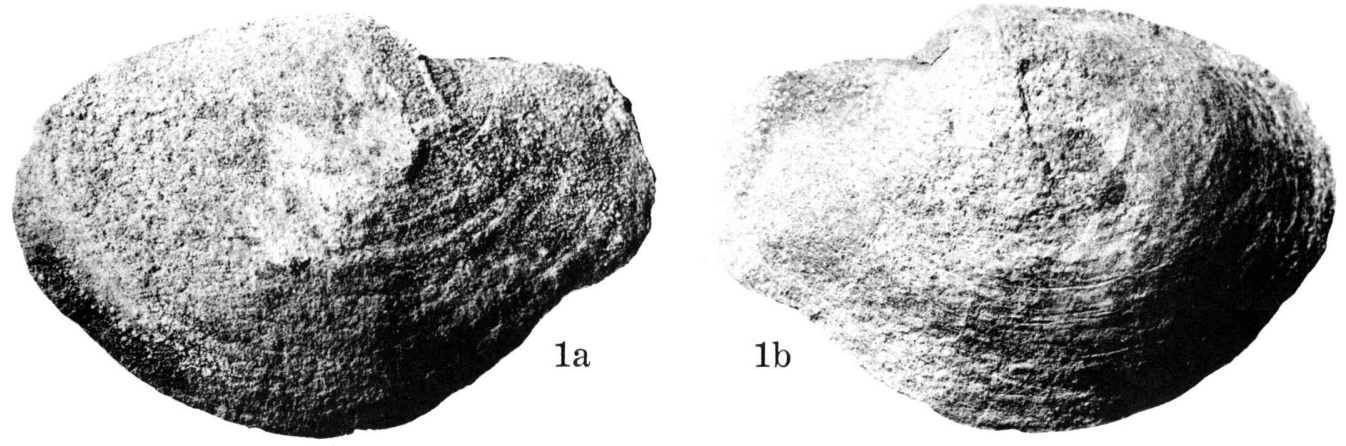

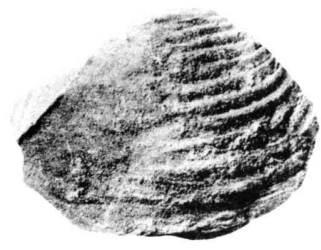

$4 \mathrm{~b}$

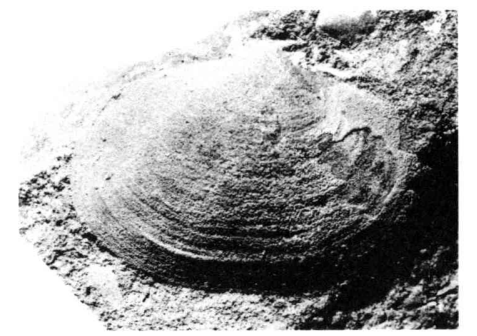

3

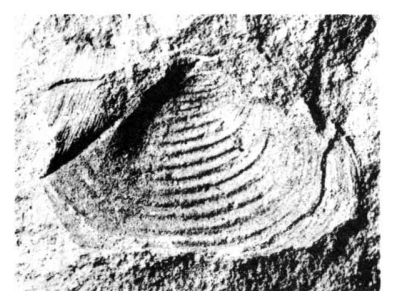

$4 \mathrm{c}$

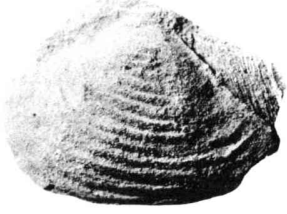

$4 \mathrm{a}$

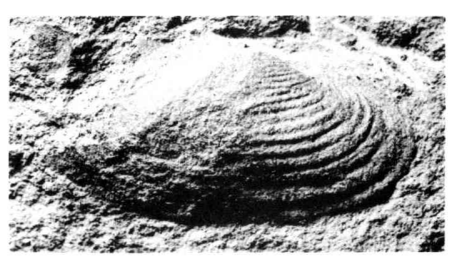

2
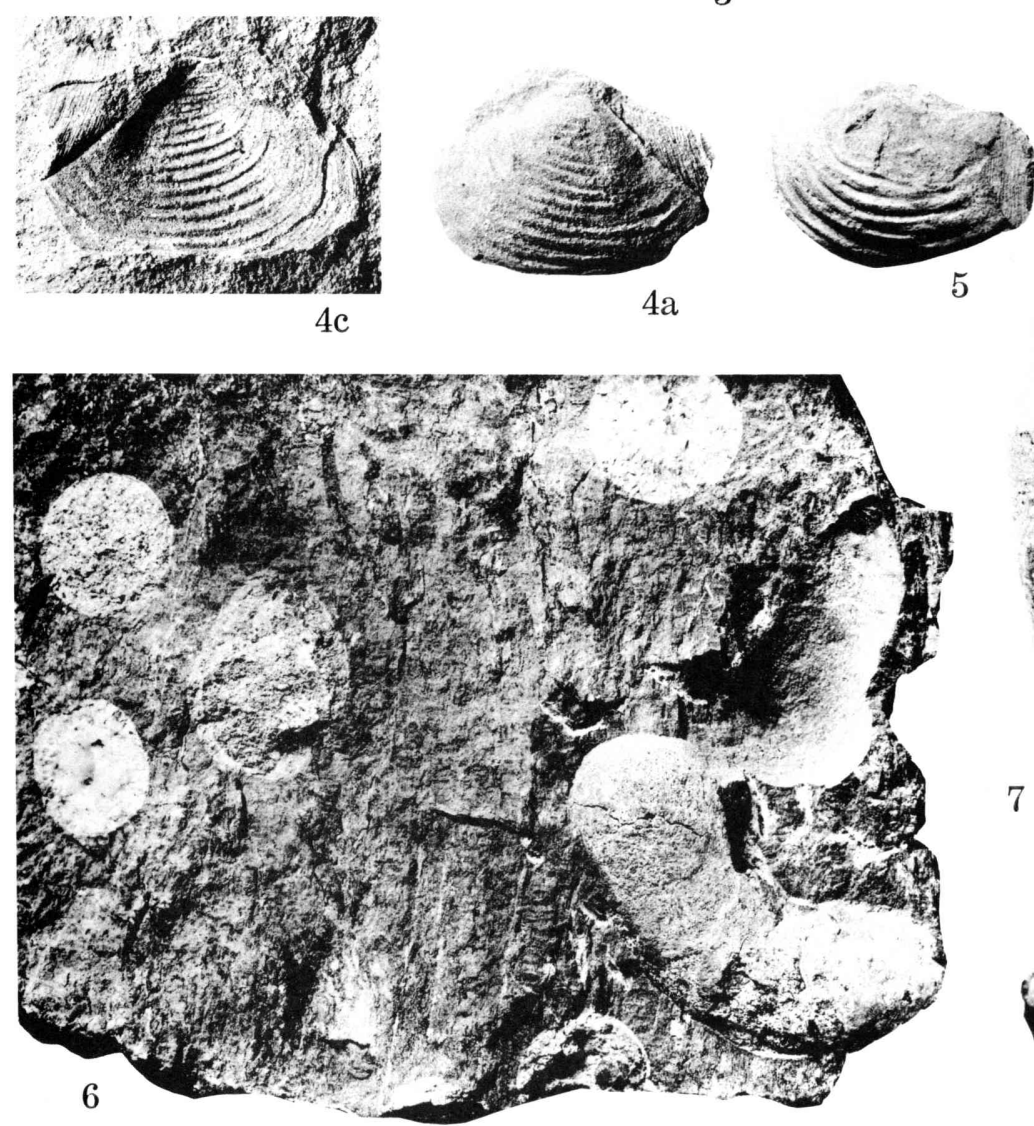

5

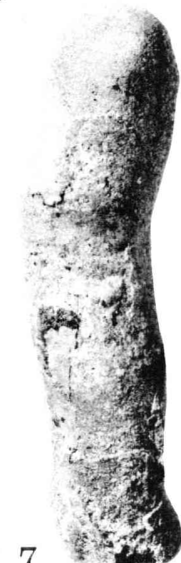

(1)

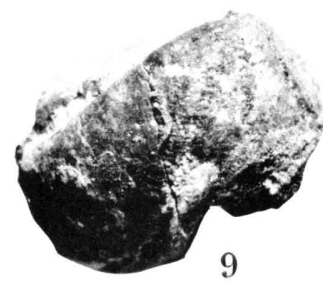

I. Hayami : Lower Cretaceous marine Pelecypods of Japan 